Portland State University

PDXScholar

1976

\title{
Some Coyote Food Habitat Patterns in the Shrub- Steppe of South-central Washington
}

\author{
Peter Frederick Stoel \\ Portland State University
}

Follow this and additional works at: https://pdxscholar.library.pdx.edu/open_access_etds

Part of the Biology Commons

Let us know how access to this document benefits you.

\section{Recommended Citation}

Stoel, Peter Frederick, "Some Coyote Food Habitat Patterns in the Shrub-Steppe of South-central Washington" (1976). Dissertations and Theses. Paper 2193.

https://doi.org/10.15760/etd.2189

This Thesis is brought to you for free and open access. It has been accepted for inclusion in Dissertations and Theses by an authorized administrator of PDXScholar. Please contact us if we can make this document more accessible: pdxscholar@pdx.edu. 
AN ABSTRACT OF THE THESIS OF Peter Frederick Stoel for the Master of Science in Biology presented 3 November 1976.

Title: Some Coyote Food Habit Patterns in the ShrubSteppe of South-central Washington.

APPROVED BY MEMBERS OF THE...THESIS COMMITTEE:

Richard B. Forbes, Chairman

Dennis W. Boddy

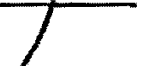

Bavid T. Clark

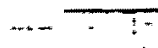

"Richard Thoms

Coyote food habits were ascertained by identifying the undigested material in 1143 scats collected at monthly intervals from specific road transects on the USERDA Hanford Reservation in Washington from 1974 to 1976. Tracks at artificially established scent posts along the principal 
transect provided evidence that the scats were left by coyotes and not bobcats or badgers. On the basin plain (150m elevation) where the Artemisia tridentata/Poa sandbergii Association predominates, the average monthly percent occurrences in the 491 scats collected in 1975 were pocket mouse 60 , leporid 39 , pocket gopher 12 , grasshopper 12, fruit 10, cricetine mice 7 , darkling beetle 6 , bird 5, reptile 4, ground squirrel 4, microtine mice 3 , and livestock 1.8. Pocket mice and leporids both occurred in every monthly sample of 1974-76. During the summer of 1974 grasshoppers were eaten in large quantities ( 85 percent occurrence), but the next year they were eaten less than half as frequently ( 37 percent) during the same period. Monthly numbers of pocket mice and cricetines live-trapped on a grid on the plain correlated significantly with the monthly percent occurrence in scats $(r=.80, p<.001$; and $\mathrm{r}=.62, \mathrm{p}<.02$ respectively).

At $500 \mathrm{~m}$ elevation in the more mesic nearby Rattlesnake Hills; covered mostly by an Artemisia tridentatal Agropyron spicatum Association, microtines dominated the diet during all seasons for an average seasonal occurrence of 83 percient. The average seasonal percent occurrence of the principal foods in 1975 were Lagurus curtatus 68, Microtus montanus 30, gopher 24, pocket mouse 14, birds 12 , leporid 8, grasshopper 7, grass 3 and darkling beetles 2 . Other studies have shown that leporids predominate 
in the coyote's diet in the plains and intermountain areas while rodents predominate in mountain and coastal areas. Coyote food habits on the Hanford plain in 1975 are unusual in that a rodent, the pocket mouse, Perognathus parvus, is the dominant item in this arid, intermountain basin instead of leporids. However, the estimated biomass of Perognathus at Hanford $\left(8.5-134 \mathrm{~kg}\right.$ per $\left.\mathrm{km}^{2}\right)$ in 1975 was comparable to the biomass of leporids in Utah ( $8.2-137 \mathrm{~kg}$ per $\left.\mathrm{km}^{2}\right)$ where the coyote's diet is about 80 percent leporid. Perognathus parvus is exceptionally numerous in the habitat type found at Hanford, and the coyote's diet reflects this abundance.

Coyote scats were significantly non-random in their distribution on the three collection transects (Chi square goodness-of-fit test $\mathrm{P}<.001$ ). Reasons discussed to explain the clustered pattern include a territorial marking function for the droppings, preference for elevated places for marking, previous droppings as stimulus, and juxtaposition of the scat concentrations to important areas such as rendezvous sites. 
SOME COYOTE FOOD HABIT PATTERNS IN THE

SHRUB-STEPPE OF SOUTH-CENTRAL

WASHINGTON

by

PETER FREDERICK STOEL

A thesis submitted in partial fulfillment of the requirements for the degree of

MASTER OF SCIENCE

in

BIOLOGY

Portland State University

1976 
TO THE OFFICE OF GRADUATE STUDIES AND RESEARCH:

The members of the Committee approve the thesis of Peter Frederick Stoel presented 3 November 1976.

\author{
$\lambda$ \\ Richard B. Forbes, Chairman
}

Dennis W. Boddy

D'avid T. Clark

Richard Thoms

APPROVED :

W. Herman Taylor, Head, Depectent of Biology

Stanfey E. Rauch, Dean, Graduate Studies and Research 


\section{ACKNOWLEDGEMENTS}

I thank Dr. Byron E. Lippert for his assistance in obtaining initial permission to start on this study at Hanford; Dr. William H. Rickard for continuing permission to study on the Hanford Reservation, to use various facilities there, and for other assistance when needed; and Dr. Richard B. Forbes for aid in completing many aspects of this project. I also appreciate the helpful advice and assistance of Drs. Dennis W. Boddy, David T. Clark, Quentin D. Clarkson, John Garland, Mark Johnson, E. L. Klepper, Matt Rand, R. Roughton, J. T. Springer, and R. E. Thoms.

A11 the animal trapping data used in this thesis was the independent work of Dr. T. P. O'Farre11, J. D. Hedlund, K. A. Gano, Dr. L. E. Rodgers and several other people. Gratitude is expressed to Dr. Rodgers, and Mr. Hedlund for permission to use their data before its publication and to K. A. Gano for collating the trapping data for me.

Special thanks is extended to Dr. T. P. O'Farrell and Steve Hoffman for taking the time to write lengthy, thoughtful commentaries on this thesis based on their expert know1edge. Dr. 0'Farrell's extensive knowledge of mammal ecology at Hanford made his criticism especially valuable.

I thank my parents, Tom and Caroline Stoel, for their understanding and support of this project. 
TABLE OF CONTENTS

PAGE

ACKNOWLEDGEMENTS $\ldots \ldots \ldots \ldots \ldots \ldots \ldots \ldots \ldots \ldots$ ii

LIST OF TABLES........................ vii

LIST OF FIGURES..............................

CHAPTER

I INTRODUCTION.................... 1

Purpose of this study............. 1

Description of the Study Area......... 2

II METHODS 6

Location of sampling area.......... 6

Method of analysis.............. 7

Scent Post Survey................ 10

III RESULTS AND DISCUSSION--COYOTE FOOD HABITS ON THE HANFORD PLAIN $\ldots \ldots \ldots \ldots \ldots \ldots \ldots \ldots \ldots \ldots$

Mammals.................... 11

Great Basin Pocket Mice........ 18

Leporids................. 23

Pocket Gophers.............. 27

Townsend's Ground Squirre1....... 28

Cricetine Mice.............. 29

Microtine Mice.............. 30

Livestock................. 30 
Birds...................... 32

Reptiles..................... 33

Insects .................. 33

Orthoptera................ 34

Tenebrionidae.............. 36

Fruit.................. 37

Carnivore response to scent posts

along the ALR.............. 39

Discussion................... 40

IV RESULTS AND DISCUSSION--COYOTE FOOD HABITS

IN THE RATTLESNAKE HILLS.............. 44

V DISTRIBUTION OF COYOTE SCATS ON THE ALR..... 51

VI SUMMARY........................ 59

REFERENCES CITED......................... 62

APPENDIX A - Coyote scat analysis - Army Loop Road... 66

APPENDIX B - Coyote scat analysis - Gate 111 Road.... 86

APPENDIX C - Coyote scat analysis - Snively Road..... 92

APPENDIX D - Coyote scat analysis - 1200 Foot Road... 98

APPENDIX E - Coyote scat analysis - Dry Creek Road.... 105

APPENDIX F - Coyote scat analysis - Cold Creek Road... 108 APPENDIX G - Coyote scat analysis - N. E. Area...... 110 
CHAPTER

APPENDIX H - Number of pocket mice (Perognathus parvus)

live-trapped on a one ha square grid of 100

traps near Rattlesnake Springs, 1971-1976 (1974-

75 data - Rodgers and Hedlund 1976;1971-73 and

1976 data -- L. E. Rodgers, J. D. Hedlund,

K. A. Gano, and T. P. O'Farrel1, unpublished... 113 


\section{LIST OF TABLES}

TABLE

PAGE

I Mammals on or near the Hanford Reservation.... 15

II Comparison of the percent occurrence of several

important mammals found in the coyote diet

in the Rattlesnake Hills and on the low

elevation plain March 1975 - February 1976.. 19

III Small mammals Iive-trapped monthly on a

trapping grid near the Army Loop Road May

1974 - February 1976 (from Hedlund and

Rodgers 1976) ...................

IV Comparison of percent occurrence of darkling

beetles in coyote scats on the Army Loop

Road with the number pitfall-trapped at

Redox Pond and B-C Crib (darkling beetle data

from Rodgers et al 1976)................ 38

$V$ Comparison of the total number of each species

trapped and the average 1975 seasonal

percent occurrence in the Rattlesnake

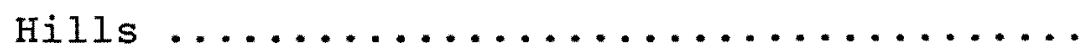




\section{LIST OF FIGURES}

FIGURES

PAGE

1 Map of coyote scat collection areas and areas

where prey populations were surveyed

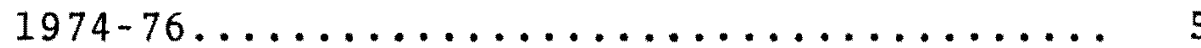

2 Percentage of coyote scats containing major

food categories, Army Loop Road and

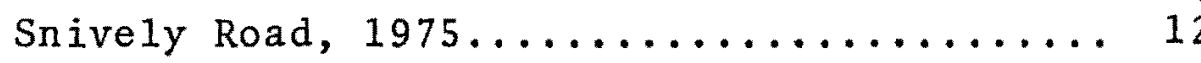

3 Important foods of coyotes in Artemisia/Poa

habitat on the Hanford Reservation,

Washington, as determined by analysis of

scats collected from the Army Loop Road

between May 1974 and February 1976...... 13

4 Comparison of monthly occurrence of pocket

mice in coyote scats collected from the

ALR with numbers of individual pocket mice

trapped monthly near the ALR (Hedlund and

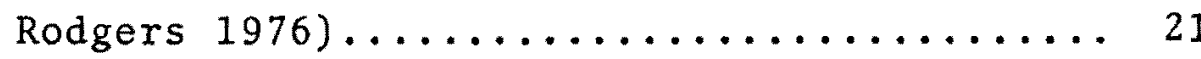

5 Regression of the percentage of ALR coyote

scats containing pocket mice against the

number of individual pocket mice live-

trapped monthly near the ALR 1974-76

(Hedlund and Rodgers 1976)............ 22 
6 Negative correlation between the percent occurrence of leporids and the percent occurrence of rodents in ALR coyote scats during the months of September-February 1974-76 $(\mathrm{r}=-.92, \mathrm{~N}=8, \mathrm{p}<.01)$. Data from the other months is presented but not

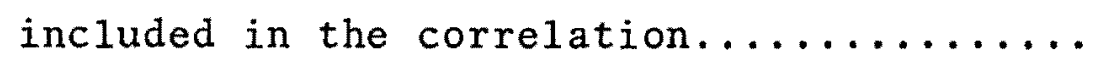

7 Negative correlation between the percent occurrence of pocket mice (Perognathus parvus) in ALR coyote scats during the months of September-February 1974-75 $(\mathrm{r}=-.80, \mathrm{~N}=8, \mathrm{P}<.02)$. Data from other months is presented but not included

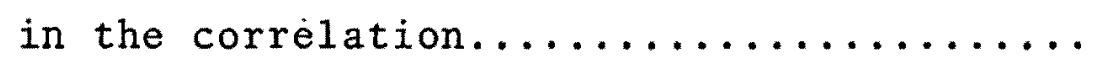

8 Comparison between ocular estimates of grasshopper density per $\mathrm{m}^{2}$ (B-C Crib area, Sheldon and Rodgers 1976) and percentage of coyote scats on the ALR containing grasshoppers, $1974 \ldots \ldots \ldots \ldots \ldots \ldots \ldots \ldots .35$

9. Seasonal food habits of coyotes in the Rattlesnake Hills as determined by analysis

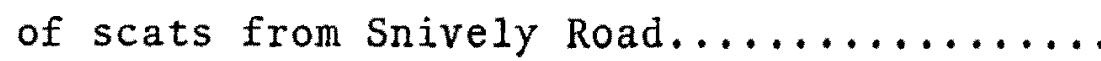


10 Comparison of numbers of smal1 mammals 1 ivetrapped with small mammals in coyote scatsRattlesnake Hills, Snively Road 1975.

(Trapping data J. D. Hedlund, K. A. Gano,

D. T. McCullugh, unpublished) .........44 4

11 Monthly distribution of coyote scats on the Army Loop Road, $1974-76 \ldots \ldots \ldots \ldots \ldots \ldots$

12 Distribution of coyote scats on Snively Road,

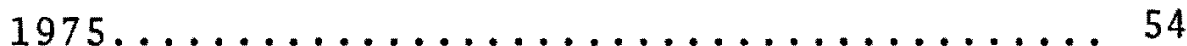

13 Distribution of coyote scats on Gate 111 Road,

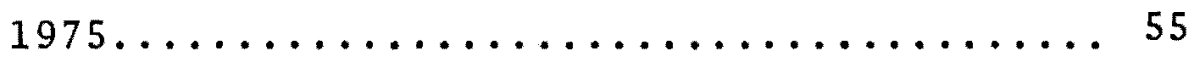




\section{CHAPTER I}

\section{INTRODUCTION}

\section{Purpose of This Study}

The populations of many large predatory mammals such as the wolf, cougar, and grizzly bear have been much reduced in the contiguous United States largely because of loss of wildlife habitat and conflict with man's pastoral activities. However, one medium sized carnivore, the coyote Canis Zatrans), has adapted remarkably well to man's encroachment on its habitat. Because of the coyote's relative abundance compared to large carnivores, and the continuing coyotelivestock controversy, research interest in this animal has greatly increased in recent years.

More than thirty coyote food studies have been published in the past fifty years. Though these studies have become more detailed, there is still a vacuum in our knowledge of the coyote's diet in many specific habitats. A review of the literature shows that coyotes eat practically all available animal and vegetable materials, but there is great variation in the relative proportions of the different food types. This variation means that coyote food habits in each habitat type generally must be ascertained by a specific food habits study. Previous coyote food studies have not included monthly quantitative data on the abundance 
of prey species to compare with the quantitative data on the coyote's diet.

The United States Energy Research and Development Administration's (ERDA) Hanford Reservation in the Columbia basin of south-central Washington offers a unique site for the study of coyote ecology in relatively undisturbed habitat because of its large area and protected coyote population. In addition, studies of small mammal and insect populations by other scientists at Hanford provides data that can be used to better understand the relationship between coyote food habits and prey abundance.

The specific objectives of this research project were to 1) describe seasonal variation in the diet of the Hanford coyote population, 2) compare the frequency of occurrence of small mammals in coyote scats with the frequency of capture of small mammals in live traps in the same area throughout the period of scat collection, and 3 ) examine the distributional pattern of coyote scats on the roads where they were collected.

Description of The Study Area

The Hanford Reservation lies in the rain shadow of the Cascade Mountains in one of the most arid regions of the Pacific Northwest. Average annual precipitation at the Hanford Weather Station in the middle of the Reservation is only $170 \mathrm{~mm}$ ( 60 year average), falling mostly between october and Apri1. Summers are hot and dry (mean July maximum 
$33.3^{\circ} \mathrm{C}$ ); winters are $\operatorname{cool}$ (mean January minimum $-10.2^{\circ} \mathrm{C}$ ) (Rickard 1972). Precipitation in the Rattlesnake Hills above above 365 meters elevation is appreciably higher (approximately $230 \mathrm{~mm}$ ) than it is on the plain $(170 \mathrm{~mm}$ ) (Hinds and Thorp 1974).

The $1300 \mathrm{~km}^{2}$ Reservation is mostly a plain crossed by rolling hills and ridges varying in elevation from 150 to 229 meters. This plain is broken only by Gable Mountain (335 meters elevation) in the northeast area and by the Columbia River. The Reservation is bordered by the Columbia River on the north and east, and the Rattlesnake Hills on the west which rise steeply to 1,067 meters. Across the river on the east are the White Bluffs $(274 \mathrm{~m})$. The Reservation surrounded by the river and these hills is thus a well defined topographic unit. Lands adjacent to the river on the north and northeast are administered by state and federal wildlife agencies and are not agricultural.

The Reservation is entirely within the Artemisia tridentata/Agropyron spicatum (Sagebrush/bunchgrass) Zone (Daubenmire, 1970). Most of the Reservation, which is on the plain below $300 \mathrm{~m}$ elevation, consists of Artemisia tridentata/Poa sandbergii (Sagebrush/Sandberg's bluegrass) Association where it has not been severely disturbed by past agricultural activity. In disturbed areas Bromus tectorum (cheatgrass brome) is prevalent (Rickard 1972). The study area on the plain was limited to the Artemisia tridentatal 
Poa sandbergii Association. Areas along the river were not surveyed.

Above $360 \mathrm{~m}$ in the more mesic Rattlesnake Hills, the vegetation is dominated by the Artemisia/Agropyron Association. This area of the Rattlesnake Hills covers about 88 $\mathrm{km}^{2}$ of the $1300 \mathrm{~km}^{2}$ Reservation (Figure 1). The flora along Snively Road (Figure 1) consists primarily of the Artemisial Agropyron Association with deciduous shrubs such as black cottonwood, chokecherry, smooth sumac, Lewis mock-orange bordering a spring-fed brook. This riparian vegetation provides a habitat for many birds, including California quail and chukar. In Snively Basin there are abandoned wheatfields which are now dominated by cheatgrass brome and tumble mustard (Sisymbrium altissimum). For a more detailed description of the Rattlesnake Hills habitat see Rickard (1972) . 


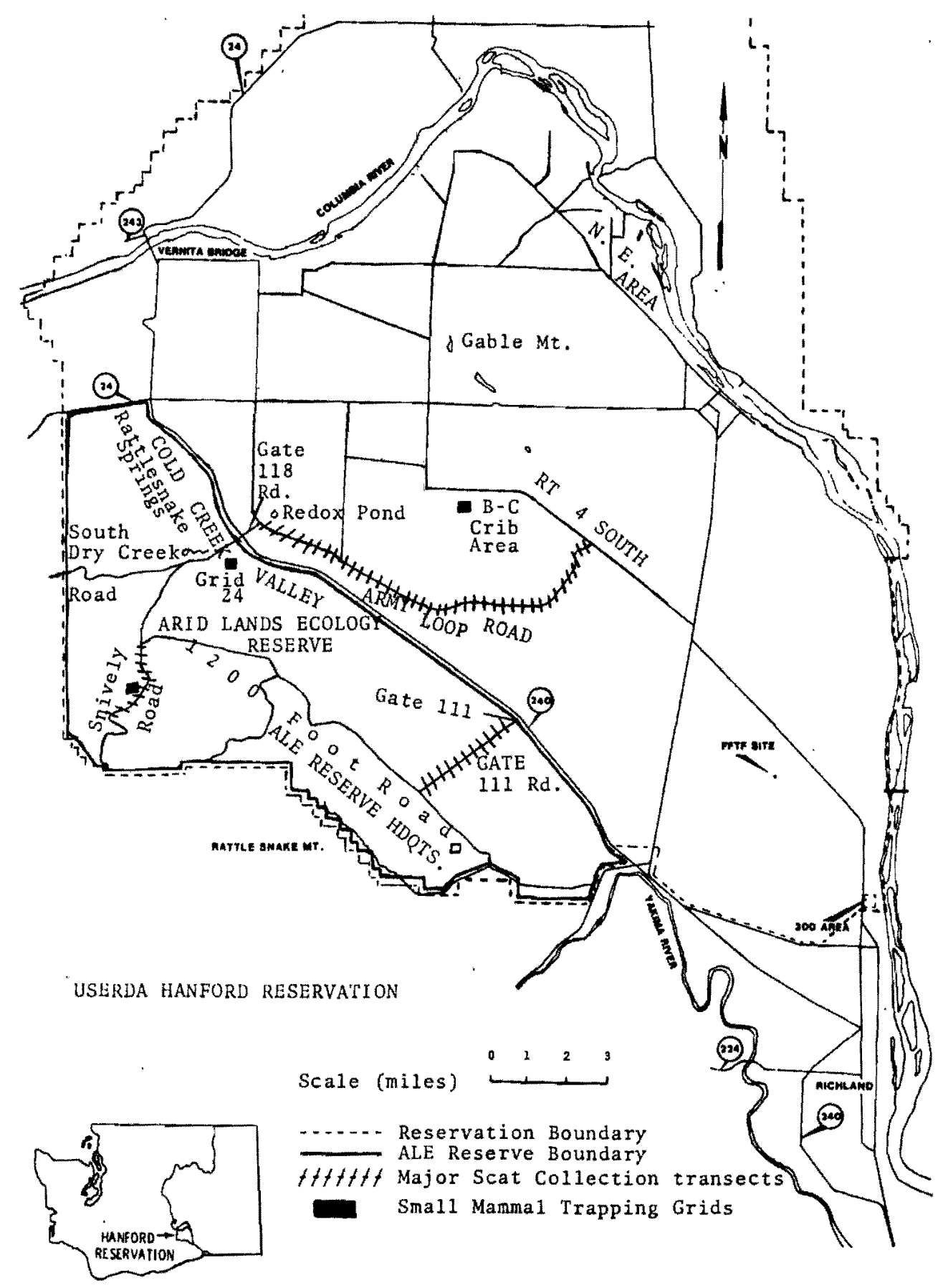

Figure 1. Map of coyote scat collection areas and areas where prey populations were surveyed 1974-76. 


\section{CHAPTER II}

\section{METHODS}

Coyote food habits were determined by identifying the undigested items found in 1152 scats collected from specific roads on the Hanford Reservation between March 1974 and February 1976.

\section{Location of Sampling Areas}

Coyote scats were collected from the lower elevation plain and the Rattlesnake Hills. On the plain, scats were collected along a single transect consisting of $17.7 \mathrm{~km}$ section of the Army Loop Road (ALR) between Route 4 south and the Gate 118 Road (Figure 1). The ALR is a paved road 4 meters wide. It is within the fenced and locked enclosure of the Reservation, not accessible to the general public and not a main thoroughfare; it is probably traveled by two or three cars per day on the average. The pavement made the scats clearly visible; collection was easier than from the other collection roads, which were all dirt. Collections from this road during four months of 1974 (May, June, July, and November) and every month between February 1975 and February 1976 produced 694 scats.

Scats were also collected from three other areas on the plain to see if the distribution of scats on ALR was 
representative of that on the Reservation plain in general (see Appendix). A carnivore scent post survey conducted on the ALR provided evidence that the scats analyzed were in fact from coyote and not from bobcats or badgers.

In the Rattlesnake Hills 113 scats were collected from the Snively Canyon Road between March 1975 and February 1976. This transect consisted of the $4.5 \mathrm{~km}$ section of the road between the 1200 Foot Road and the bottom of the switchback at 579 meters elevation (Figure 1).

Method Of Analysis

A few scats were broken apart and analyzed in the field when it could be seen that they consisted totally of a single easily-identifiable item, e.g., darkling beetles or apples. Most scats were analyzed in the laboratory by a procedure derived from Burrows (1968) and Korschgen (1969).

1) Each scat was placed in a five quart plastic pail of warm water with some detergent and allowed to soak ten minutes or more. Five pails were processed at a time. The scat number was written on the container each time the scat was trasferred to a new container.

2) The scat was broken manually in the soaking solution. Rubber gloves were worn.

3) The bucket contents were then poured into a sieve with a mesh of $0.351 \mathrm{~mm}$ and rinsed thoroughly 
with warm water.

4) The scat material remaining on the screen was washed into a pan which was filled with water. This separated the hair, chitinous insect parts and other light material, which floated on the surface from the bones and seeds which sank to the bottom. The light weight material, usually hair, was poured back into the sieve; the heavy material (teeth and bones) were examined in one inch of water.

5) Teeth and hair were identified to genus by using keys to skulls and hair (G1ass 1951, Mayer 1952, and Moore 1974) and by comparison to known specimens in the Portland State University Collection of Vertebrates.

6) Guard hairs were selected from the hair in the sieve and examined under a compound microscope. Each scat was checked especially for the presence of leporid hair if leporid teeth or toenails had not already been found.

The frequency of occurrence method of reporting food habits does not accurately reflect the relative volume of foods eaten because items occurring in small amounts (e.g., grass) will be counted equally with those occurring in large amounts, ignoring their respective volumes. Some step to compensate for this bias does seem necessary. A number of approaches have been taken. Meinzer et al (1975) identified 
the items in each of one hundred point samples taken from each scat. This gave a frequency of occurrence in the scat that more accurately reflected the volume occupied by each item. However, the fact that the volume of some foods $(e \cdot g$. , meat) are digested and absorbed far more than other items (e.g., chitinous insects) introduces inherent bias in the scat sample that makes such lengthy procedures, or tedious separation and measurement, of questionable value.

Knowlton (1964), analyzing dry scats, visually estimated the volume of items in each scat. He distinguished three volume categories, "major" (40-100\% of the scat), "minor" (5-39\%), and "trace" (<5\%). In this study washing the scats made finding and identifying items in the scats easier and more pleasant. However, it also made the volume occupied by the various items difficult to estimate visually since the material is thoroughly mixed. Therefore, only the two volume categories, "trace" ( $<10 \%$ of the scat) and "major" (10-100\%), were used in this study.

In tabulating the results (Appendix A through G) two figures are given for each food category - the percent "major" occurrence, $i . e$. , the percentage of scats that contained a "major" portion of the item, and a percent "total" occurrence, i.e., the percentage of scats that contained any amount of the item even trace amounts. If these two figures are the same it means the item is eaten in substantial quantities whenever it is eaten. If the percent 
total occurrence is much larger then it means the coyote eats that item frequently in small quantities (e.g., grass). Total occurrences are listed in the appendices, but in the text all percent occurrences discussed are occurrences of major amounts.

\section{Scent Post Survey}

In order to see if carnivores other than coyotes (e.g., bobcats and badgers) were using the ALR and thus possibly depositing scats there also, fifty scent posts were set along 14.7 miles of the Army Loop Road. Each post consisted of a perforated plastic capsule containing one gram of fermented egg scent powder provided by the U. S. Fish and Wildlife Service. The capsule was one-half inch above the ground on a stick and surrounded by sifted soil that provided a soft substrate to retain footprints of any animal approaching the capsule. The scent posts were constructed on alternating sides of ALR at 0.3 mile intervals adjacent to the road where scats were collected. The posts were monitored for five days in the fall of 1974 and 1975. 


\section{CHAPTER I I I}

\section{RESULTS AND DISCUSSION--COYOTE FOOD HABITS ON THE HANFORD PLAIN}

Fichter, et al (1955) described the coyote's diet in terms of four principle food categories - mammals, birds, insects and fruit.' These categories are applicable in most places the coyote lives, including the Columbia Basin country where this study was done. The relative importance of these categories varies seasona11y, annually and by 1ocation. At Hanford during 1974-1975 the order of importance for these categories was mammal, insect, fruit and bird on the plains, with birds becoming second in importance in the Rattlesnake Hills (Figure 2).

\section{MAMMALS}

Mammals were consistently the most important food source over an annual period (Figures 2, 3). Of the 42 species of mammals found on or near the Hanford Reservation, 19 species were found in the 1152 scats analyzed (Table I). The mammal remains found in coyote scats varied with the altitude at which the scats were found. Approximately

\footnotetext{
A fifth category might be grass, which is found all year in small amounts. A few scats consist almost entirely of grass. This suggests the grass is eaten deliberately and thus should be considered a food item.
} 


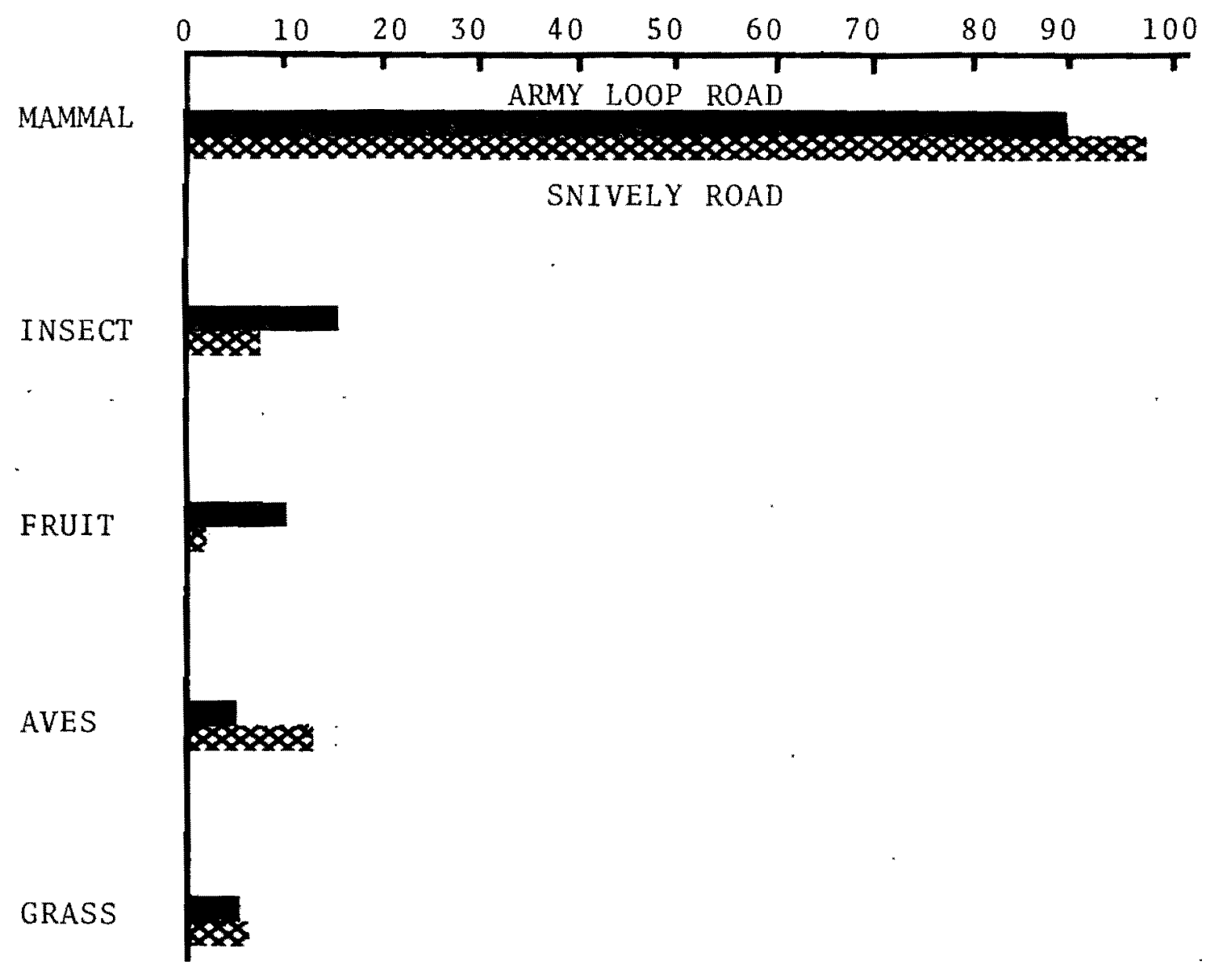

Figure 2. Percentage of coyote scats containing major food categories, Army Loop Road and Snively Road, 1975. 
Figure 3. Important foods of coyotes in Artemisial Poa habitat on the Hanford Reservation, Washington, as determined by analysis of scats collected from the Army Loop Road between May 1974 and February 1976. 

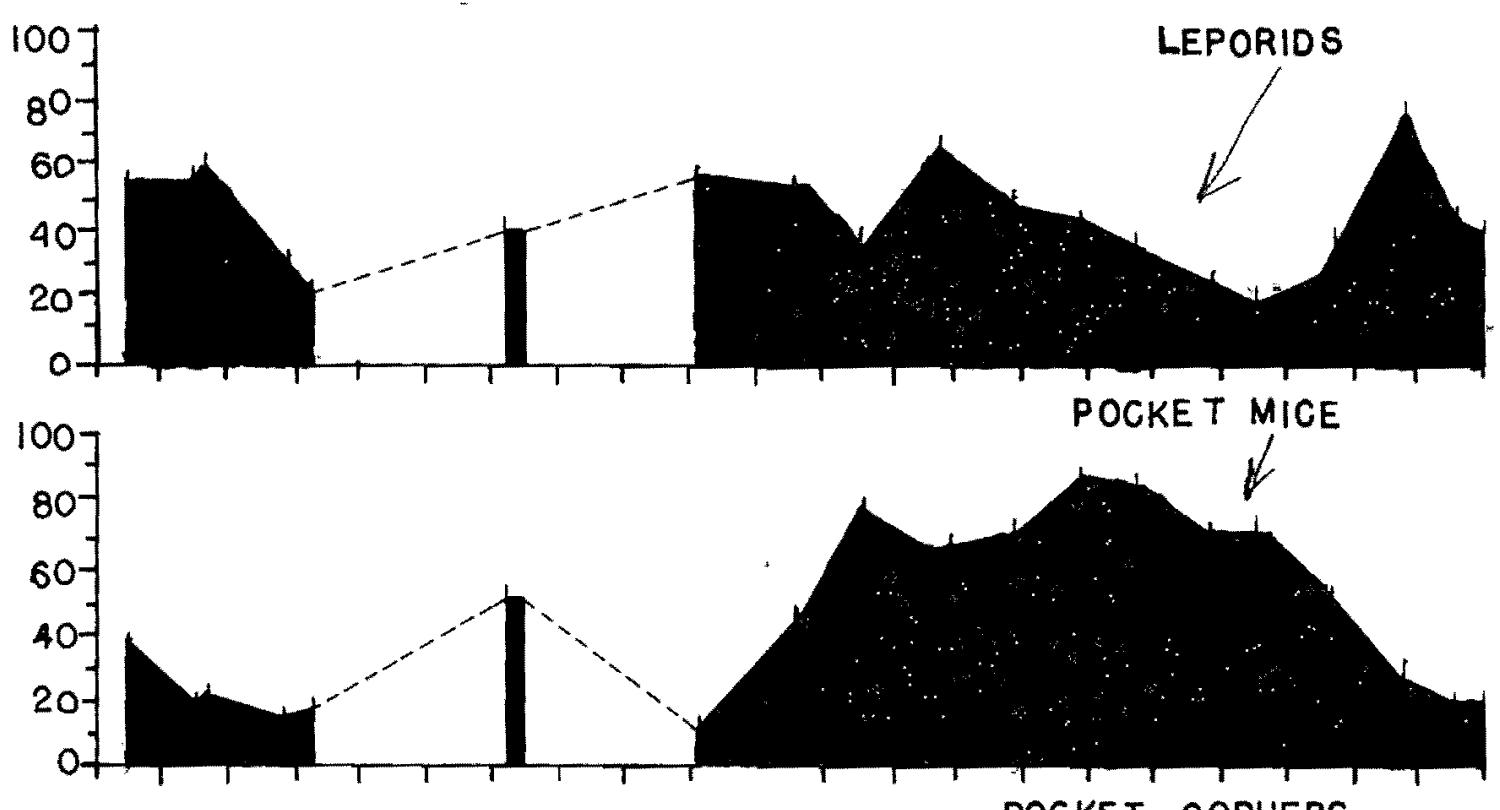

07
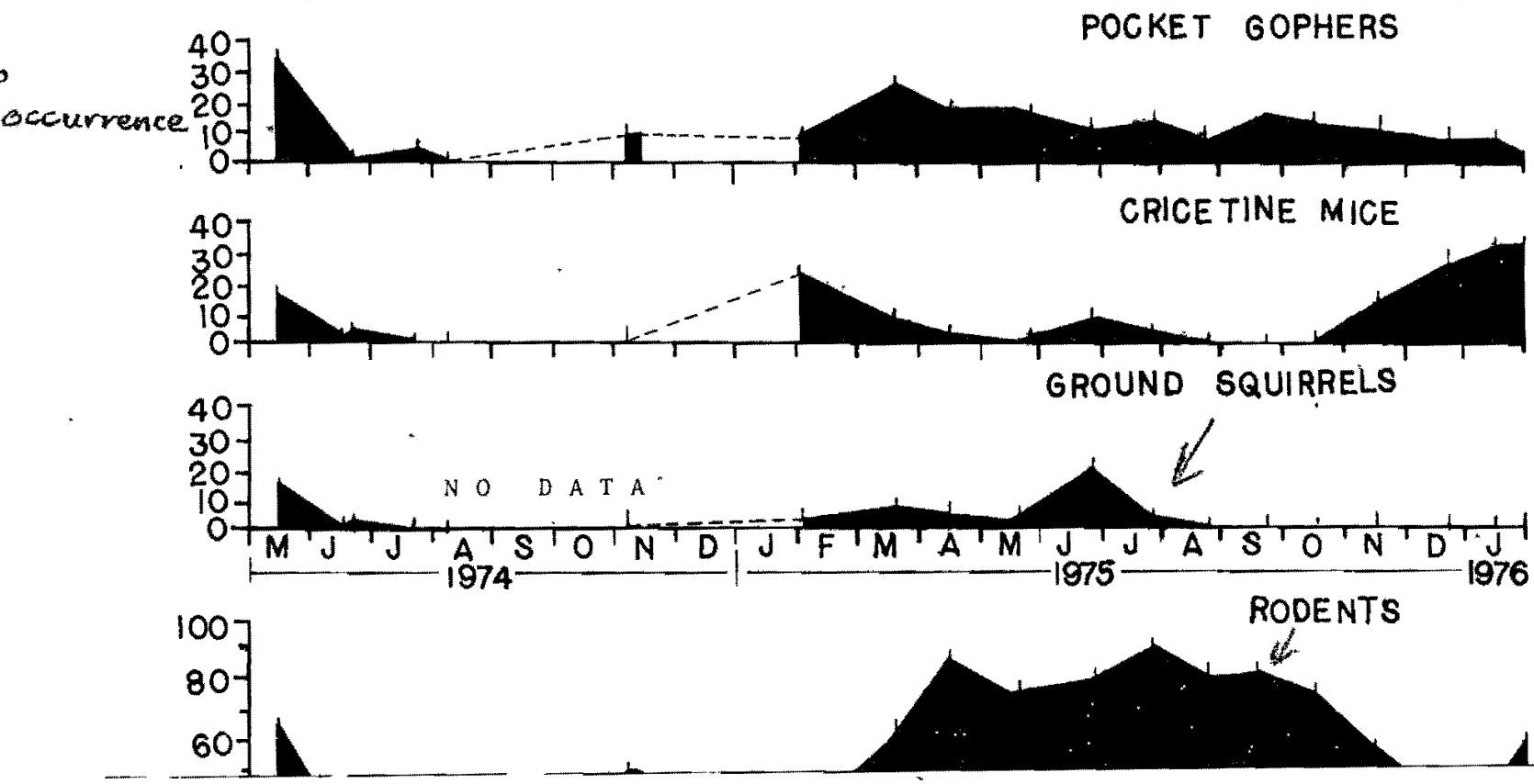

RODENTS

d

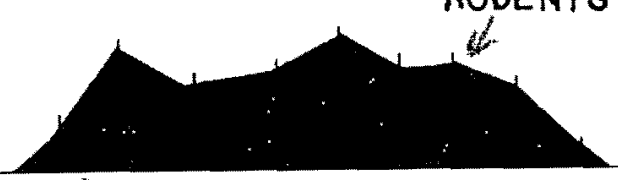

$-$ 


\section{TABLE I}

MAMMALS RECORDED ON OR NEAR THE HANFORD RESERVATION (ITEMS FOUND IN COYOTE SCATS ARE MARKED AS FOLLOWS: - SNIVELY CANYON; * ARMY LOOP ROAD

- BOTH SNIVELY AND ARMY LOOP ROAD)

Order Insectivora

Soricidae

Sorex vagrans

sorex merriami

Order Chiroptera

Vespertilionidae

Myotis Zucifugus

Lasionycteris noctivagans

Lasiurus cinereus

Order Lagomorpha

-* Leporidae

syzvizagus nuttazzii

Lepus californicus

Order Rodentia

Sciuridae

Eutimias minimus

- Marmota flaviventris

- Spermophizus townsendii

Geomyidae

-* Thomomys tatpoides
Vagrant Shrew

Merriam's Shrew

Little Brown Myotis

Silver-haired Bat

Hoary Bat
Nuttall's Cottontail

B1ack-tailed Jack Rabbit
Least Chipmunk

Yellow-bellied M rmot

Townsend's Ground

Squirre1

Northern Pocket Gopher 
Heteromyidae

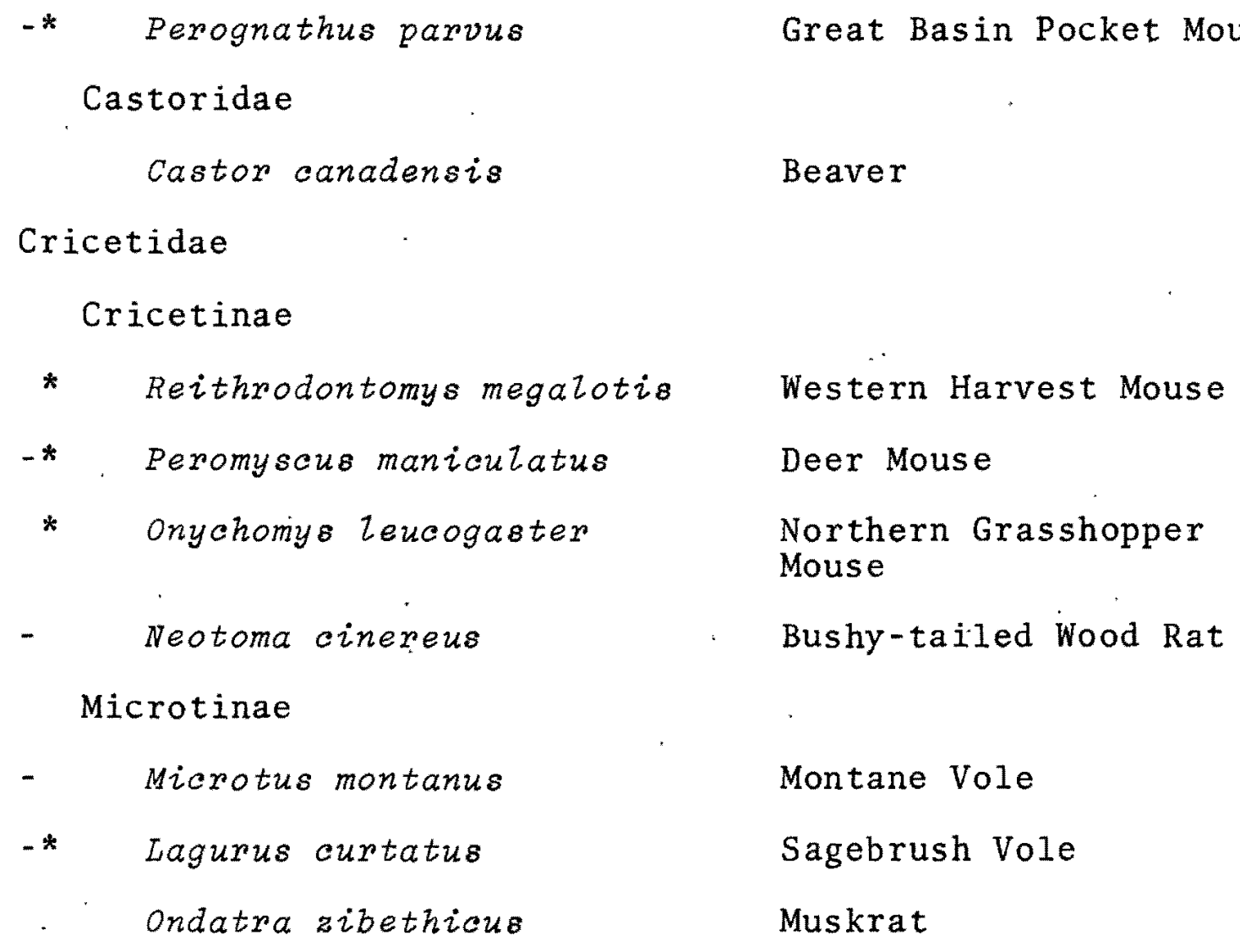

Muridae

$\begin{array}{ll}\text { Rattus norvegicus } & \text { Norway Rat } \\ \text { - Mus musculus } & \text { House Mouse } \\ \text { Erethizontidae } & \text { Porcupine } \\ \text { * Erethizon dorsatum } & \\ \text { Order Carnivora } & \\ \text { Canidae } & \text { Coyote } \\ \text { * Canis Zatrans } & \text { Domestic Dog } \\ \text { Canis famiziarus } & \\ \text { Procyonidae } & \text { Raccoon }\end{array}$


Mustelidae

$\begin{array}{ll}\text { Mustela frenata } & \text { Long-tailed Weasel } \\ \text { Mustela vison } & \text { Mink } \\ \text { Taxidea taxus } & \text { Badger } \\ \text { Spilogale gracilis } & \text { Western Spotted Skunk } \\ \text { Mephitis mephitis } & \text { Striped Skunk } \\ \text { Lutra canadensis } & \text { River otter }\end{array}$

Felidae

Felis rufus

Bobcat

Eelis catus

Domestic Cat

Order Perissodactyla

Equidae

* Equus cabalzus

Horse

Order Artiodactyla

Suidae

Sus sorofa

Pig

Cervidae

Cervus ezaphus

Wapiti

-* odocoizeus hemionus

Mule Deer

odocoizeus virginianus

White-tailed Deer

Bovidae

* Bos taurus

Cattle

* Ovis aries

Domestic Sheep 
$88 \mathrm{~km}^{2}$ of the land along the western boundary of the Hanford Reservation is above 365 meters elevation. There the predominant mammals found in scats differ from those found on the rest of the Reservation (Table II). These mammals are discussed more fully in Chapter IV, On the rest of the Reservation, consisting of plains about $1300 \mathrm{~km}^{2}$ in extent, Perognathus parvus is the predominant item found in scats. Comparison of scats collected along the ALR and those collected in other areas on the plain indicates that the coyote's food habits are similar over most of this lowland area. A possible exception might be areas immediately adjacent to the Columbia River. No sampling was done there.

Great Basin Pocket Mice

Great Basin Pocket Mice (Perognathus parvus) were the most frequently occurring item in coyote scats on the Hanford Reservation plain. Their occurrence exceeded 40 per cent in every month of this study except during the winter, and every monthly sample collected from the Army Loop Road contained some $P$. parvus remains (Fig. 3).

Live-trapping of small mammals near the Army Loop Road from 1974 to 1976 (Hedlund and Rodger 1976) provided a picture of the monthly availability of Perognathus to the coyote. Pocket mice were trapped at very low levels from two to three months each winter (Appendix H). During this period they are believed to be underground in a torpid state, periodically waking to eat from stored caches of 
TABLE II

COMPARISON OF THE PERCENT OCCURRENCE OF SEVERAL

IMPORTANT MAMMALS FOUND IN COYOTE SCATS FROM

THE RATTLESNAKE HILLS AND ON THE LOW

ELEVATION PLAIN MARCH 1975 -

FEBRUARY 1976

Pocket mouse

Perognathus parvus

\author{
Rattlesnake \\ Hills \\ (Snively Road) \\ Army Loop
}

15.0

60.4

Rabbit

8.7

38.7

Pocket gopher

Thomomys talpoides

25.0

12.2

Cricetine mice

0.0

7.0

Ground squirre1

. Spermophizus townsendii

2.2

4.5

Voles

Microtus, Lagurus

82.5

2.7

Birds

13.0

4.3

Livestock

1.0

1.8 
seeds (O'Farrell et al 1975). Occurrence of pocket mouse remains in scats follows this pattern, dropping off sharply in early winter (Fig. 4). The pocket mice emerge in February; they are again trappable and also resume an important place in the coyote's diet.

There is a peak in occurrence of pocket mice in scats in the late summer and fall of 1974 and 1975. There is also clear evidence of a peak in occurrence in April 1975 (Fig. 3). The trapping data show peaks in the same months (Fig. 4).

O'Farrel1 et al's (1975) data indicate that adult female pocket mice emerge later than males, and both are most active and breeding at the end of April. This explains the peak occurrence of pocket mice in scats collected in April. Adult pocket mice bear one to three litters per year, depending on food resources, store food underground, and cease above ground activity by July after only 60 to 90 days of above ground activity. The next peak in pocket mouse trappability and occurrence in scats represents the activity of the offspring of the litters born in the spring. These are subadults gathering seeds to store in their underground food caches; they seemingly provide the summer peak in occurrence in coyote scats. The correlation between the percent occurrence of pocket mice remains in scats and the number of individuals caught in traps each month is high (Fig. 5). Overall, the coyotes' food habits closely follow 


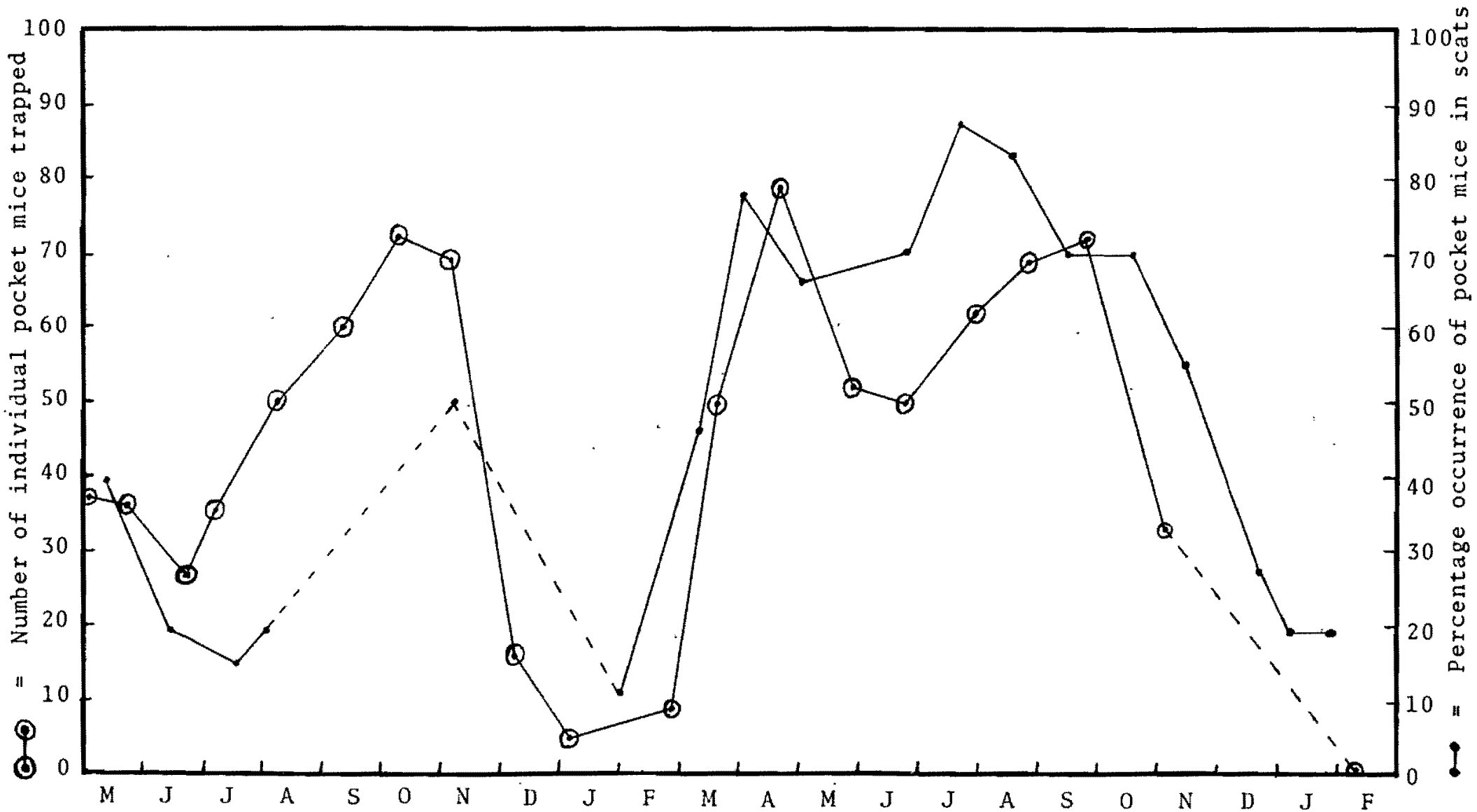

Figure 4. Comparison of monthly occurrence of pocket mice in coyote scats collected from the ALR with numbers of individual pocket mice trapped monthly near the ALR (Hedlund and Rodgers, 1976). 


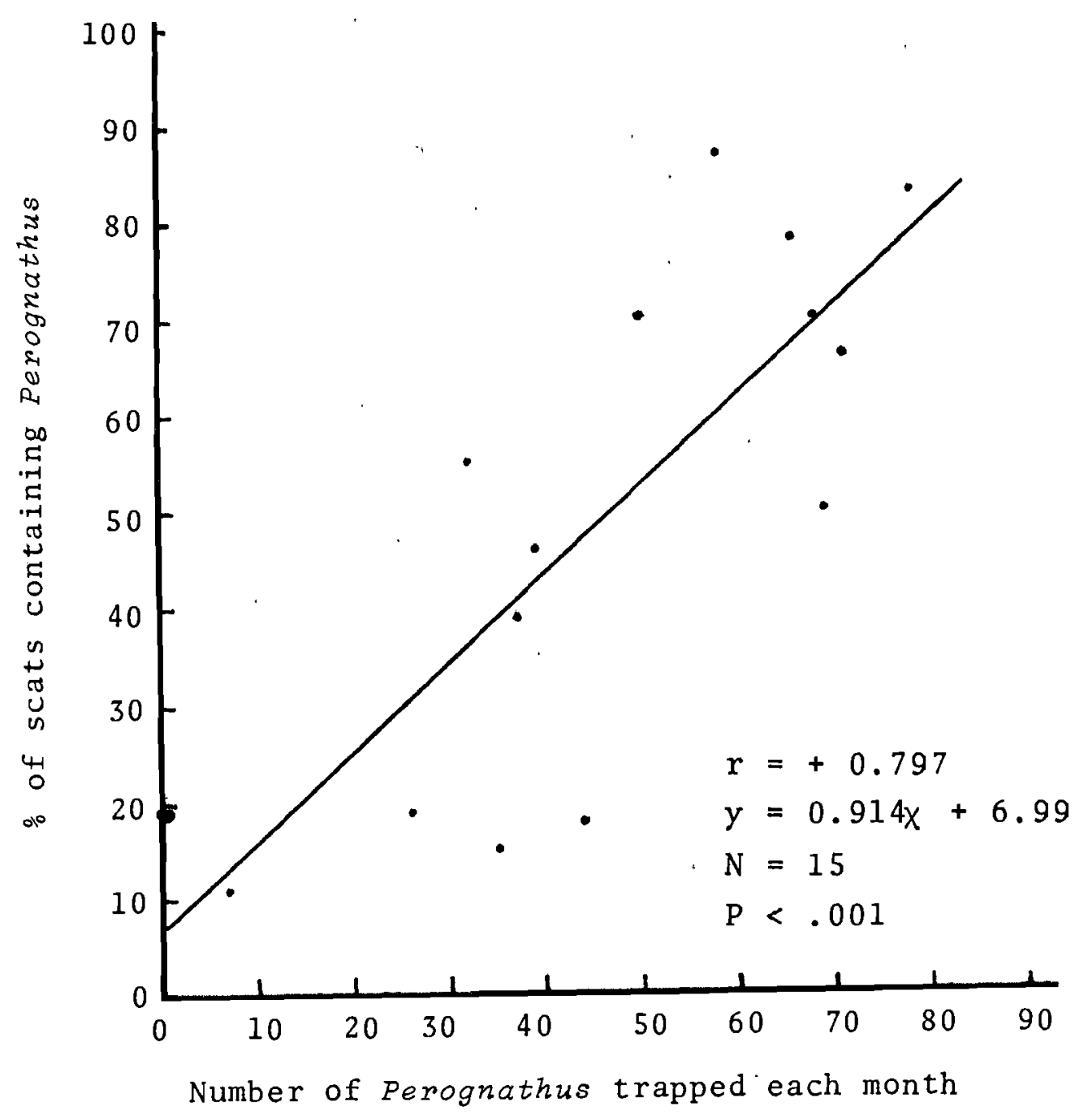

Figure 5. Regression of the percentage of ALR coyote scats containing pocket mice against the number of individual pocket mice live-trapped monthly near the ALR 1974-76 (Hedlund and Rodgers, 1976). 
the availability of the most numerous rodent species in this area.

An unexpected finding was the occurrence of pocket mice in some scats through the winter months when pocket mice are vitually untrappable. Winter 1974-75 was unusual with a few pocket mice caught each month. Though no trapping was done in December of January 1975-76 it appears from the pattern in previous years that none would have been trapped (Appendix $\mathrm{H}$ ). Yet in three scat collections in December and January pocket mice were always present in about 20 percent of the scats. This suggests that coyotes were either hunting harder for the mice in winter, or there were more active pocket mice around than the trapping suggests, or both. There were clearly some pocket mice available to the coyotes during December and January 1975-76.

Leporids

Remains of Nuttall's cottontail (Sylvilagus nuttallii) and the black-tailed jackrabbit (Lepus californicus) were found in 42 percent of the scats collected on the ALR (average of twelve months sampled between February 1975 and February 1976). These two rabbit species are not readily distinguishable on the basis of hair and teeth found in scats according to Moore (1974) and Mayer (1952), so they are lumped together in this study.

occurrence of leporids in coyote scats collected during 1974 and 1975 was lowest in the late summer and early 
fall and high during winter and spring. There is no clear explanation for the decline in leporid occurrence at the end of the summer in both 1974 and 1975. No quantitative information has been gathered on leporid population dynamics at Hanford. Therefore it is not possible to say whether this decline in leporid consumption is related to a decline in the leporid population or possibly a diversion in coyote interest caused by the high pocket mouse population.

The occurrence of leporids and the occurrence of rodents in coyote scats were inversely related during the fall and winter months but not during the spring and summer (Fig. 6). The correlations for the months September through February were $\mathrm{r}=-.80(\mathrm{~N}=8, \mathrm{P}<.02)$ for Perognathus versus leporids (Fig. 7) and $r=-.92(N=8, P<$ .01) for all rodents versus leporids. During the spring and summer months the correlations were not significant for Perognathus versus leporids, or for all rodents versus leporids. Instead both rodents and leporids occurred at high frequencies during most spring and summer months, except when grasshoppers were very abundant in July 1974 (Fig. 6).

Leporid occurrence was highest in a sample of 15 scats collected December 23, 1975 when snow covered the ground; 75 percent of the scats contained leporid remains (Fig. 3). This was the only sample collected when the 


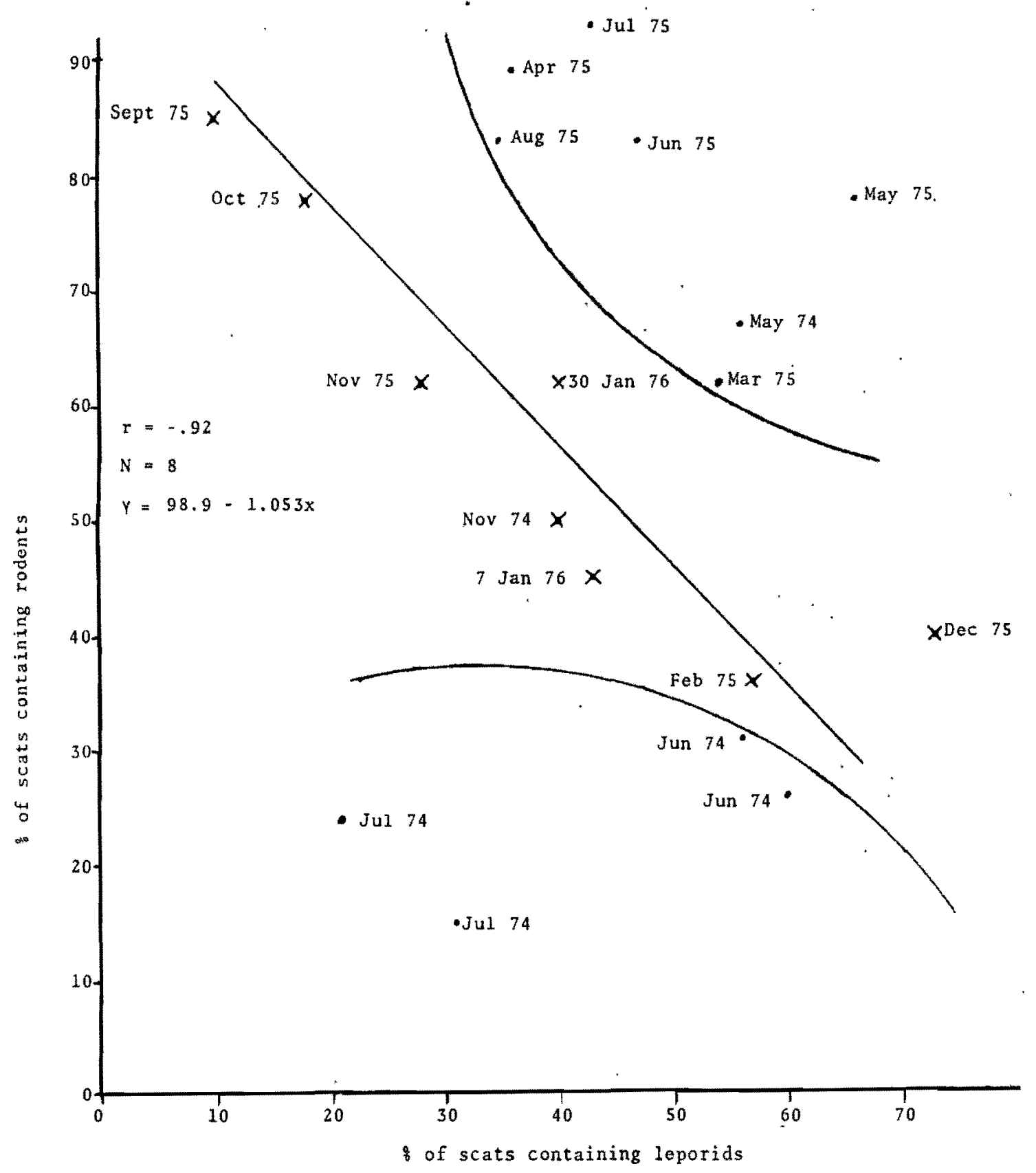

Figure 6. Negative correlation between the percent occurrence of leporids and the percent occurrence of rodents in ALR coyote scats during the months of September-February $1974-76 \quad(r=-.92, N=8, P<.01)$. Data from the other months is presented but not included in the correlation. 


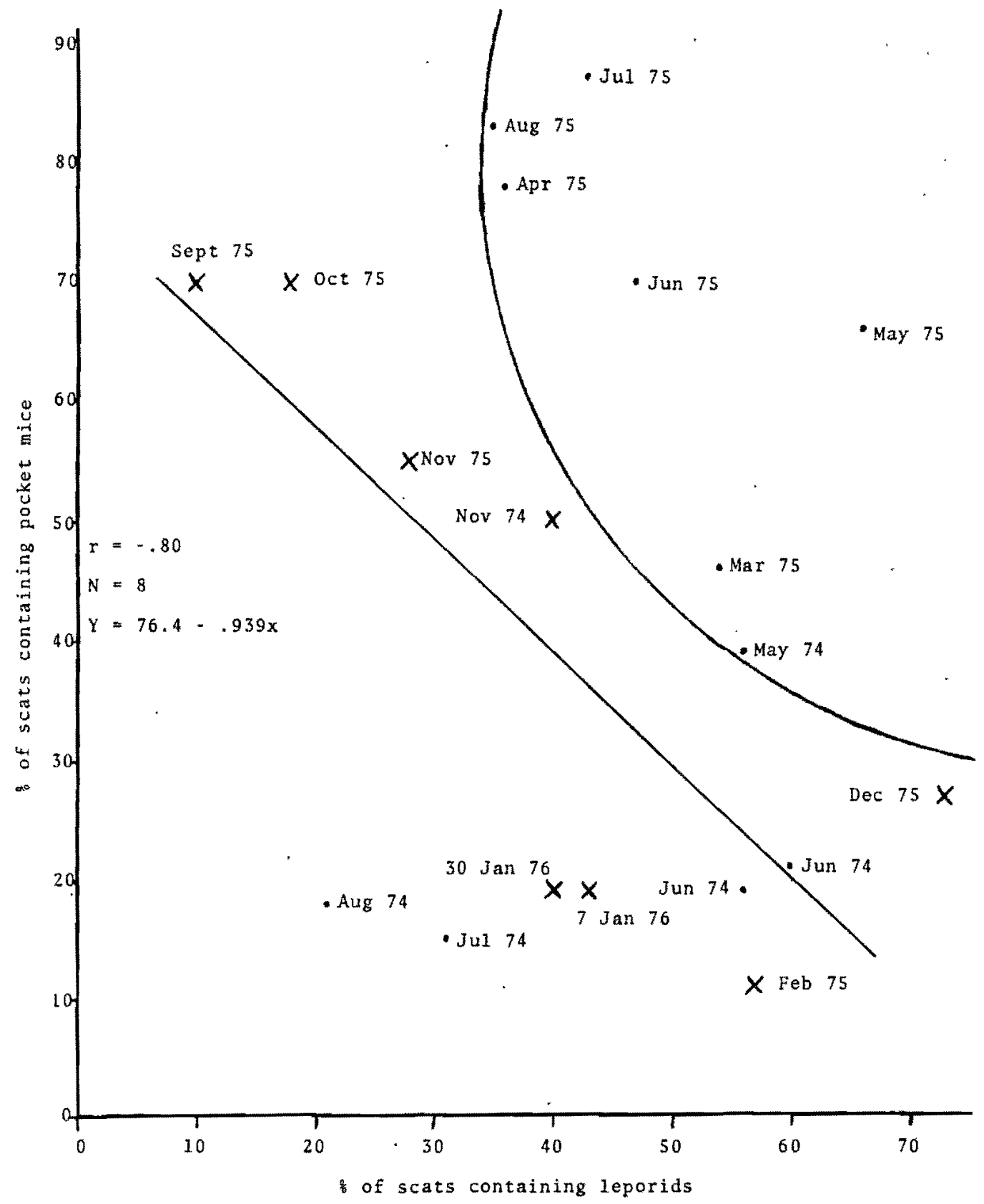

Figure 7. Negative correlation between the percent occurrence of leporids and the percent occurrence of pocket mice (Perognathus parvus) in ALR coyote scats during the months of September-February 1974-76 ( $\mathrm{r}=-.80, N=8$, $P$ $.02)$. Data from other months is presented but not included in the correlation. 
ground was snow covered. This high occurrence of leporids, along with the lowest occurrence of rodents during 1975 ( 40 percent), suggests that winter leporid consumption in this area is greatly increased by snow accumulation on the ground. This is similar to Gier's observation concerning coyote food habits in Kansas that "..during January and February, particularly when there is snow protecting the rodents and covering most other food materials, rabbit remains occurred in 60 to $80 \%$ of the stomachs and made up considerably over half the contents." (Gier 1968).

Since 1962 a population of black-tailed jackrabbits in the Great Basin has been monitored in the Curlew Valley of northern Utah $725 \mathrm{~km}$ SE of Hanford (Gross et al, 1974; Wagner and Stoddart, 1972). In most years, the Curlew Valley jackrabbits produce four litters, the first in midFebruary and the last in early July. Thus jackrabbit populations in Utah, and probably at Hanford, would be high in late summer. However, data from coyote food habits at Hanford do not confirm this. Instead of eating leporids, Hanford coyotes were eating grasshoppers, darkling beetles and especially pocket mice.

\section{Pocket Gophers}

Northern pocket gophers (Thomomys talpoides) were found in coyote scats along the Army Loop Road every month of the year, for an average monthly occurrence during 1975 
of 12.2 percent. Though their remains were never very abundant, pocket gopher was the item that occurred with the most consistent frequency in the scats (Fig. 3). Pocket gophers do not hibernate or become inactive any time of the year (Ingles 1965) and thus are always available to coyotes in varying amounts. The peak occurrence was in March.

\section{Townsend's Ground Squirre1}

Townsend's ground squirrels (Spermophizus townsendii) were eaten only in the spring. Therefore the average monthly occurrence for 1975 was only 4.5 percent, but a peak of 23 percent occurrence was reached during May-June 1975 .

Ground squirrels on the ALE Reserve feed above ground during the day from late January to June then enter estivation and are in hypothermic torpor for the next seven months (O'Farrell 1975b). Therefore they are available as food for coyotes only in the spring. On the low elevation grid near Rattlesnake Springs no spermophilus townsendii have been caught. In past years (1968-71) at other trapping locations in all habitat types on the Arid Lands Ecology Reserve only 2 out of 14 Spermophilus were trapped in the Artemisia/Poa association, the habitat where the ALR scat collection transect is located. Spermophilus were trapped mostly in the Artemisia/Agropyron association above 360 meters elevation (O'Farrell 1975a, b; O'Farrell et al 1972, 1974; 
Hedlund et al 1976b). There ground squirrels find the green vegetation necessary for growth during their active period in the spring (O'Farre11 1975b). However, ground squirrels are found at low elevations where green vegetation exists, such as around riparian habitat along the Columbia River (O'Farre11 1975b).

Besides their 1 imited annual activity period and their need for fresh herbage a third factor affecting their distribution, and thus having a big impact on their availability to coyotes, is their habit of living in colonies (MacClintock and Ferguson 1970) which are widely scattered at Hanford. Spermophilus may be a substantial part of the diet of those local coyotes that visit these colonies in the spring.

\section{Cricetine Mice}

Altogether, cricetines were found in coyote scats on the ALR at an average monthly occurrence of 7.0 percent in 1975. Deer mice (Peromyscus maniculatus) were the most conmon cricetine, but since it was usually difficult to distinguish them from harvest mice (Reithrodontomys megalotis) based on scat material these two species are treated as one category, Cricetinae. Bushy-tailed wood rats (Neotoma cinerea) occurred in one scat collected in Snively Canyon. The Northern grasshopper mouse (onychomys leucogaster) occurred in one scat collected on the ALR in August 1975. 
Remains of deer mice and harvest mice were found frequently in scats during the winter and only rarely in the summer (Fig. 3). This reflects the capture pattern on the sma11 mammal trapping grid (P1ot \#24) near the ALR. Eleven of the 13 cricetines trapped were captured during the months December through March (Table III); these were the same months when cricetines were found most frequently in scats (Fig. 3).

\section{Microtines}

The sagebrush vole (Lagurus curtatus) and montane vole (Microtus montanus) occurred at low frequencies on the Army Loop Road together averaging only 2.7 percent occurrence. They occurred in scats collected between February and April 1975 and between November 1975 and February 1976. Peak occurrence was 19 percent, in January 1976 when Peromysous was also at peak occurrence and Perognathus activity was low. The two microtines occurred at about the same frequency. Along with their occurrence in ALR winter scats, microtines were also trapped for the first time in three years at the low elevation grid (two Lagurus curtatus February 11-12, 1976. Hedlund and Rodgers 1976, see Table III).

Livestock

The, average monthly occurrence of cow, sheep and horse hair in scats on the Army Loop Road was 1.8 percent. Of the 
TABLE III

SMALL MAMMALS LIVE-TRAPPED MONTHLY ON A TRAPPING GRID NEAR THE ARMY LOOP ROAD MAY 1974 - FEBRUARY 1976 (FROM HEDLUND AND RODGERS 1976)

\begin{tabular}{|c|c|c|c|c|c|c|c|c|c|c|c|c|c|c|c|c|c|c|c|c|c|c|c|}
\hline & \multicolumn{6}{|c|}{1974} & \multicolumn{14}{|c|}{1975} & \multicolumn{3}{|c|}{$\therefore 1976$} \\
\hline & $\begin{array}{c}\mathrm{M} \\
1-3\end{array}$ & $\begin{array}{c}M \\
21-25\end{array}$ & $\mathrm{~J}$ & $\mathrm{~J}$ & $A$ & $\mathrm{~s}$ & 0 & $\mathrm{~N}$ & $\mathrm{D}$ & $J$ & $F$ & $M$ & $A$ & $M$ & $\mathrm{~J}$ & $\bar{J}$ & A & $s$ & 0 & $N$ & $\mathrm{D}$ & $\mathrm{J}$ & $\mathrm{F}$ \\
\hline $\begin{array}{l}\text { Perognathus } \\
\text { parvus }\end{array}$ & 37 & 35 & 26 & 35 & 49 & 60 & 72 & 69 & 16 & 5 & 9 & 50 & 79 & 52 & 50 & 62 & 69 & 72 & - & 33 & - & - & 0 \\
\hline $\begin{array}{l}\text { Peromyscus } \\
\text { manticulatus }\end{array}$ & 1 & 0 & 0 & 0 & 0 & 0 & 0 & 0 & 2 & 2 & 3 & 2 & 0 & 0 & 0. & 0 & 0 & 1 & - & 0 & - & $\cdot$ & 2 \\
\hline $\begin{array}{l}\text { onyohomys } \\
\text { Zeucogaster }\end{array}$ & 0 & 0 & 0 & 0 & 0 & 0 & 0 & 0 & 0 & 4 & 0 & 0 & 0 & 0 & 0 & 0 & 0 & 0 & $=$ & 0 & - & - & 0 \\
\hline $\begin{array}{l}\text { Lagurus } \\
\text { curtatus }\end{array}$ & 0 & 0 & 0 & 0 & 0 & 0 & 0 & 0 & 0 & 0 & 0 & 0 & 0 & 0 & 0 & 0 & 0 & 0 & - & 0 & - & - & 2 \\
\hline
\end{tabular}


694 scats analyzed from the ALR, one collected in February 1975 contained wool. Cattle hair was found more frequently, but only in winter and early spring. Horse hair was found in five scats in May 1974 collected on the Gate 111 Road and in two scats collected on the ALR in January 1976. Livestock grazing is prohibited on the Hanford Reservation except for 1 imited experimental purposes. However, domestic animals occasionally break in from surrounding areas. I observed and photographed free-running horses on the Reservation July 4, 1974, $18 \mathrm{~km} \mathrm{NE}$ of Gate 111. The occurrences of livestock in scats probably resulted from coyotes scavenging a few carcasses. One carcass, a calf, was found near Highway 240 at Gate 118. It may be the source of cattle hair found on the ALR scats in early 1975. Besides this carcass I have no specific information on sources of the livestock hair in scats.

\section{BIRDS}

Bird remains were found in a few scats sporadically throughout the year, for an average monthly percent occurrence of 5 percent. Most remains (feathers) were not identified beyond the class Aves. In a few cases parts of bills and feet were found; these were from the most common passeriform species found on the Reservation, horned larks (Eremophilus alpestris) and meadowlarks (Sturnella neglecta). There was an increase in birds in the coyote's diet in 
winter.

\section{REPTILES}

Lizards and snakes were found in coyote scats at an average occurrence of 4 percent. They occurred in scats found in August 1974, February 1975, and every month from June 1975 to February 1976. The remains were all of snakes except for a few lizards found in February 1975 and January 1976. The lizards were probably side-blotched (Uta stanaburiana) the most common lizard on the Reservation (Fitzner 1976). No short-horned lizard remains were found though I have seen them on the Army Loop Road. Snakes identified were the gopher snake (Pituophus mezanoleucus), yellowbellied racer (Coluber constrictor) and one rattlesnake (Crotalus viridis) occurrence, identified by the presence

of a rattle segment in a scat. Rattlesnakes have previously been recorded in coyote diets (Sperry 1941, Ferrel et at 1953).

\section{INSECTS}

Insects are seasonally important in the coyote's diet at Hanford. The average monthly occurrence for 1975 was 15 percent. Three families were principally involved in 1974 and 1975 - Tenebrionidae (darkling beetles, Coleoptera), Acrididae (Short-horned grasshoppers, Orthoptera), and Tettigoniidae (long-horned grasshoppers, Orthoptera). 


\section{Orthoptera}

Orthoptera were particularly prevalent in the ALR scats during the summer of 1974 , occurring in 87 percent of the scats in "major" amounts in both the June 21 sample of 16 scats and in the 38 scats collected between July 30 and August 6 (Fig. 3). Specific types of Orthoptera were not identified in the scat samples. I collected one specimen, a dectid (Apote notabizus) on June 21, 1974, in the vicinity. These animals were very numerous on the road at that time. Many legs and ovipositors observed in analyzed scats resembled those of this specimen. In an unrelated study at a site near the B-C Crib (Fig. 1) five kilometers north of the ALR in similar habitat Sheldon and Rodgers (1976) identified 14 species of grasshoppers, including both vegetation and ground dwelling species. Grasshopper density on the ground in 1974 peaked in late June and July according to their ocular estimates. Coyote consumption of grasshoppers, as determined by analysis of ALR scats, peaked during the same period (Fig. 8).

An interesting question is whether the high consumption of grasshoppers in the summer of 1974 depressed the consumption of other food items, particularly rabbits and pocket mice. Figure 3 shows that rabbits were at high occurrence in scats through June when grasshoppers were also heavily eaten. After all scats were cleared from the road July 5 the fresh scats deposited in July showed a sharp 


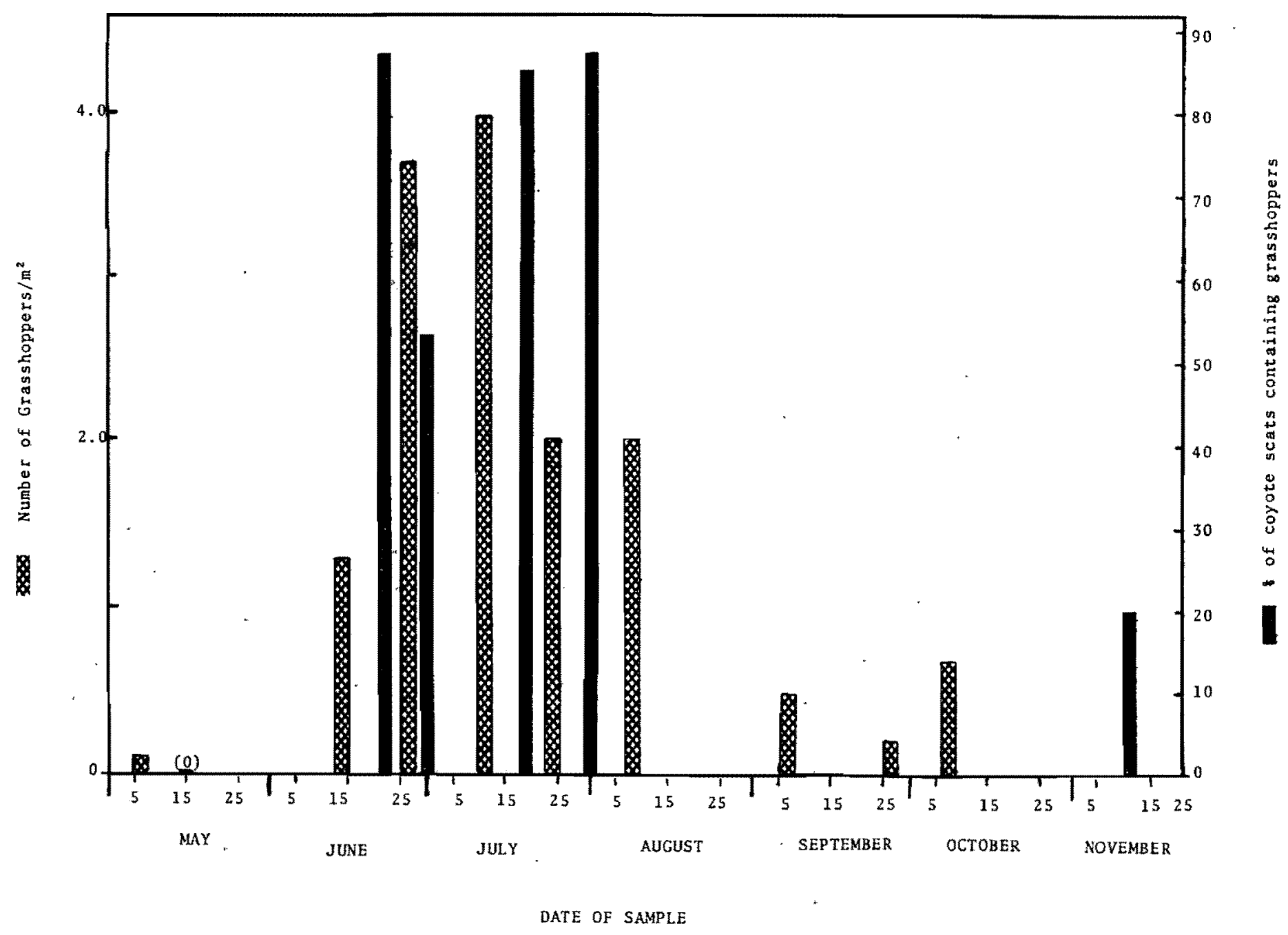
Figure 8 . Comparison between ocular estimates of grasshopper density per $\mathrm{m}^{2}$
(B-C Crib area, Sheldon and Rodgers, 1976) and percentage of coyote scats on the ALR contalning grasshoppers, 1974 . 
reduction in rabbit consumption while grasshopper occurrence was maximal. Pocket mouse consumption also continued a downward trend in July when small mammal trapping showed rapidly increasing pocket mouse activity (Fig. 4). This data suggests a coaction resulting in depressed consumption of mammals during periods of very high insect abundance.

In 1975 dectids were not observed in coyote scats, but acridid grasshoppers occurred from July through November. The November peaks in 1974 and 1975 are consistent, about 20 percent both years. Several investigators of coyote food habits have noted significant summer or fall occurrences of acridids in coyote scats (0. Murie 1935; A. Murie 1940; Meinzer et al 1975; El1is 1959; Knowlton 1964). Fichter, et al (1955), for example, reported high summer occurrences of grasshoppers $-72,85$, and 95 percent for the summers of 1947-49 respectively - in coyote scats from an area in Nebraska. Other writers (A. Murie 1940; Ryden 1975) suggest that grasshoppers may be particularly important in the diet of young coyotes in late summer.

\section{Tenebrionidae}

Darkling beetles (Tenebrionidae) appeared in two distinct peaks in 1975 and occurred in smaller amounts during the same period in 1974 (Fig. 3). Tenebrionidae occurred at an average rate of six percent occurrence for all of 1975. The two distinct peaks were in June 1975 (27 percent occurrence) and November 1975 (24 percent). Three samples 
collected in the summer and fall 1975 had zero occurrence (Fig. 3) .

Table IV compares monthly pitfall trap data (Rodgers et $a l$ 1976) for 1974 and 1975 from two areas north of where the ALR scats were collected (Fig. 1). The reason for the lack of a fit between the occurrence of darkling beetles in scats and pitfall traps is not clear $(r=+.05, N=9)$. However darkling beetle occurrence in pitfall traps at two similar areas $8 \mathrm{~km}$ apart (Redox Pond and $\mathrm{B}-\mathrm{C} \mathrm{Crib}$ ) were also not significantly correlated $(r=+.48, N=11, .20<P<$ .10). Likewise, occurrence in scats was variable in the same month at different places on the lower plain; for example, 24 percent versus 47 percent on the ALR and Gate 111 Road respectively in November 1975. This suggests that darkling beetle activity and abundance was scattered and variable over this area so that pitfall trapping and scat collection would have to be more closely coordinated in time and distance in order to show a correlation. Pitfall trap data from 1974-1975 (Rodgers, et al 1976), and from previous years (Rickard 1970, 1971) suggests that the June peak in occurrence of darkling beetles in scats was due largely to Eleodes hispilabris and the October-November peak to Philolithus densicollis (Horn) (formerly Pelecyphorus).

\section{FRUIT}

Fruits from naturally occurring plants at Hanford were 
TABLE IV

COMPARISON OF PERCENT OCCURRENCE OF DARKLING BEETLES IN COYOTE SCATS ON THE ARMY LOOP ROAD WITH THE NUMBER OF PITFALL-TRAPPED AT REDOX POND AND B-C CRIB (DARKLING BEETLE DATE FROM RODGERS et al 1976)

\begin{tabular}{|c|c|c|c|c|c|c|c|c|c|c|c|c|c|c|c|c|c|c|c|c|}
\hline & & & & & & & & & & & & & & & & & & & & \\
\hline & M. & $J$ & $\mathrm{~J}$ & A & $\mathrm{S}$ & 0 & $\mathrm{~N}$ & D & $\mathrm{J}$ & F & $\mathbf{M}$ & A & $\mathrm{M}$ & $J$ & $J$ & A & $S$ & 0 & $\mathbf{N}$ & $\mathrm{D}$ \\
\hline \multicolumn{21}{|l|}{$\begin{array}{l}\text { Number of } \\
\text { Darkling Beetles } \\
\text { Pitfa11-trapped }\end{array}$} \\
\hline Redox Pond & 49 & 6 & 1 & 3 & 4 & 4 & - & - & - & - & - & 0 & 8 & 8 & 6 & - & 5 & 12 & - & - \\
\hline $\mathrm{B}-\mathrm{C}$ Crib & 59 & 33 & 14 & 1 & 2 & 72 & - & - & - & - & 0 & - & 6 & 2 & 3 & - & 1 & 5 & - & - \\
\hline $\begin{array}{l}\text { Percent } \\
\text { Occurrence of } \\
\text { Darkling Beetles }\end{array}$ & & & & & & & & · & & & & & & & & & & & & \\
\hline In Scats & 5 & 0 & 0 & 0 & - & - & 10 & - & - & 0 & 2 & 0 & 2 & 27 & 0 & 0 & 0 & 10 & 24 & 0 \\
\hline
\end{tabular}


not found in coyote scats. However, apples and cherries are common in coyote scats, especially in the winter, averaging 10 percent occurrence during 1975 (Fig. 3). Three possible sources for the apples and cherries are garbage from the Central Dump (landfill) located on the ALR, spillage from trucks along Highway 240 (report from John Hedlund, personal communication), abandoned orchards along the Columbia River, and orchards more than twelve miles south of the ALR on the other side of Rattlesnake Mountain.

Fruit occurred most frequent1y in the winter, with a peak of 35 percent occurrence in January. Sperry (1941) reported frozen fruit in the winter diet of coyotes in Washington; this is confirmed by this study. Ozaga and Harger (1966) also reported that frozen apples were an important item ( 31 percent occurrence) in the coyote's winter diet on Beaver Island in Lake Michigan.

\section{CARNIVORE RESPONSE TO SCENT POSTS}

No other carnivores besides coyotes were recorded at the scent posts in 1974 or 1975. During 250 scent post nights each year there were 28 coyote visits in 1974 and 23 in 1975 along the ALR. It is concluded from the lack of response by other wild carnivores that the scats on the ALR were from coyotes.

Dog tracks are usually indistinguishable from coyote tracks. However, since coyotes were seen along the ALR, 
and I neither saw nor received any reports of dogs there, it is concluded that the scent post tracks are from coyotes. Dogs were seen only once on the Reservation. On February 24, 1974 I saw two free-running dogs unaccompanied by any people near the junction of the 1200 Foot Road and Snive1y Road. The nearest human residence is $7.7 \mathrm{~km}$ away on the other side of Rattlesnake Mountain.

\section{DISCUSSION}

Pocket mice and leporids were the major items in the coyote's diet in the Artemisca tridentata/Foa sandbergii habitat type which covers most of the basin plain. This habitat is characterized by low mammal diversity (O'Farrell et al 1975). Perognathus parvus far out-numbers the other mouse species present with a population an order of magnitude greater than that of Peromyscus maniculatus, the next most abundant species (0'Farrell et al 1975).

Pocket mice occurred more frequently than leporids in scats (60 percent versus 40 percent occurrence). However, frequency of occurrence data tends to overestimate the volume of small items in the diet, such as mice, since they occur more frequently in small quantities (1ess than 40 percent of the scat) then do large items such as leporids (Clark 1972). Not counting small quantities (items occupying less than 10 percent of the scat) when calculating the percent occurrence removes some of this bias, since mice 
occur more often at such low volumes than do leporids. Yet, since mice also appear in 10 to 50 percent of the scat more often than do leporids, it might be suspected that the volume of mice in the diet is still over-estimated. Leoprids may approach pocket mice in volume in the coyote's diet rather than be considerably less, as indicated by the average frequency of leporid occurrence in scats.

Most other coyote food habit studies also show rodents and leporids as the major dietary items. Leporids usually predominate on the plains and in arid intermountain areas (Fichter et al 1955; Gier 1968; Clark 1972); rodents predominate inmountain and coastal areas (Ferrel et al 1953; A. Murie 1940) due to greater abundance of microtines there. Coyote food habits in the Artemisia/Poa habitat of Washington deviate from this pattern. It is an arid intermountain area where the results of this study show a rodent rivals rabbits as the major prey species in the coyote's diet. Sperry (1941) reports finding a similar pattern in Washington 40 years ago. He found, in 8,263 stomachs collected from 1931 to 1936 from 17 western states, that stomachs from Washington coyotes had the lowest percentage of rabbit occurrence ( 27 percent) and the highest occurrence of Perognathus (27 percent in his April samples).

In another arid intermountain area, the Curlew Valley on the Idaho-Utah border, jackrabbits were by far the predominant coyote food $[77$ percent occurrence in scats and 
72 to 95 percent occurrence in stomachs (Clark 1972). Fall jackrabbit densities varies in the Curlew valley from 1963 through 1969 from a low of 11.7 per $\mathrm{km}^{2}$ to 68.0 per $\mathrm{km}^{2}$ (Gross et al 1974). At a mean adult jackrabbit weight of $2.0 \mathrm{~kg}$ (Stoddart 1972) this jackrabbit density converts to a jackrabbit biomass range of 23.4 to $137 \mathrm{~kg}$ per $\mathrm{km}^{2}$. At Hanford the above ground biomass of Perognathus (the biomass available to coyotes) can be calculated directly from the numbers of individuals trapped on the one hectare live-trapping grid (plot \#24). Since live-trapping was conducted each month for three consecutive nights, and all individuals were marked and released, it is likely that nearly all Perognathus active each month were counted. Thus, the number of individuals captured can be used as a conservative estimate of the above ground population. Using this estimate of population and a mean weight for Perognathus of 17.4 grams (Hedlund et al 1976b; O'Farrell 1975b), above ground Perognathus biomass varied during the period of this study from $8.5 \mathrm{~kg}$ per $\mathrm{km}^{2}$ in January 1975 to $134 \mathrm{~kg}$ per $\mathrm{km}^{2}$ in April 1975. This estimate of Perognathus biomass compares well with Gross (1974) estimate of rabbit biomass which provided about 80 percent of the Curlew Valley coyotes' food and supported a coyote population there of approximately 0.7 per $\mathrm{km}^{2}$ (Clark 1972). 
It would be interesting to have as accurate an estimate of leporid density at Hanford as we have of Perognathus density so we could see how well the percent occurrence in scats correlates with the biomass of these species in the Hanford environment. However, the above calculations suggest that Perognathus biomass density at Hanford is adequate to supply the major portion of the coyote's diet for the ten months out of the year when pocket mice are active above ground, just as the scat analysis data suggests. 
CHAPTER IV

COYOTE FOOD HABITS IN THE RATTLESNAKE HILLS

Eleven collections of coyote scats (130 scats total) from Snively Road ( $366 \mathrm{~m}$ to $580 \mathrm{~m}$ elevation) covering the period of March 1975 to February 1976 shows a diet which differs markedly from that which occurred at lower elevations only $10 \mathrm{~km}$ away. These data are arranged according to season for analysis and discussion. The sagebrush vole, (Lagurus curtatus) and the montane vole (Microtus montanus) together occurred in 85 percent of the scats on the average across all seasons. These two species of voles completely dominated the coyote's diet during the year (Figure 9).

Six trapping sessions were conducted in Snively Basin in the Rattlesnake Hills between January 1975 and March 1976 (J. D. Hedlund, D. T. McCullugh, and K. A. Gano, unpublished data). Traps were set at two grids about one kilometer apart in Snively Basin both at $533 \mathrm{~m}$ elevation. The results from the two trapping grids have been combined in the following discussion.

Lagurus consistently occurred in a high percentage of coyote scats throughout 1975, averaging 66 percent occurrence (Fig. 9). Conversely, the trapping rate for Lagurus fluctuated widely, from one individual in August to twenty 


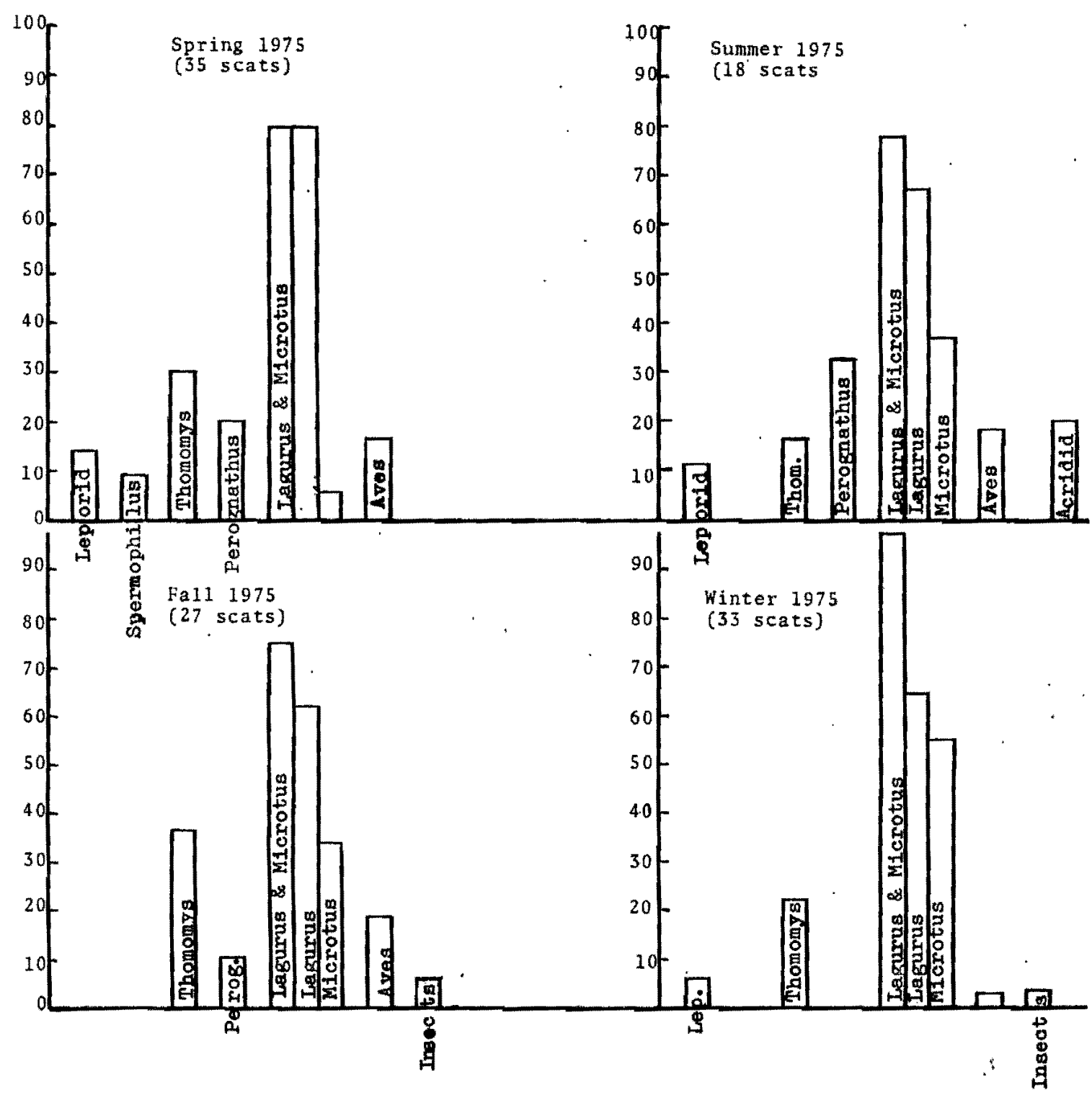

Figure 9. Seasonal food habits of coyotes in the Rattlesnake Hills as determined by analysis of scats from Snively Road. 
in September. There is a tendency for the percent occurrence in the scats to rise and fall slightly with corresponding changes in numbers of individuals trapped. However, the occurrence rate in scats is consistent compared to the sharp twenty-fold fluctuations in trapping rates during 1975 (Figure 10).

The explanation for this divergence between trapping and scat results may be simply that the coyotes are hunting over a large range of habitats in the Rattlesnake Hills differing in faunal abundance from the trap grid areas, and may find a dependable source of voles throughout the year elsewhere than on the trapping grids. Specifically, many Lagurus eaten by coyotes may have been caught above the 533 meter grids. O'Farrell (1972, 1975a) found, during small mammal surveys from 1968 to 1971, that Lagurus were trapped most frequently above 910 meters and rarely below 300 meter meters. In contrast, the lower plain (Chapter III) is more monotonous and thus, though coyotes range over a wide area there also, wherever they go they are sampling prey populations which are fluctuating like those on the trapping grid near Rattlesnake Springs.

Perognathus parvus occurred in at least a small number of scats every month from April through November 1975. There were no occurrences in the samples collected in winter or early spring. Average occurrence was 15 percent throughout 1975. Trapping results on the two Snively 


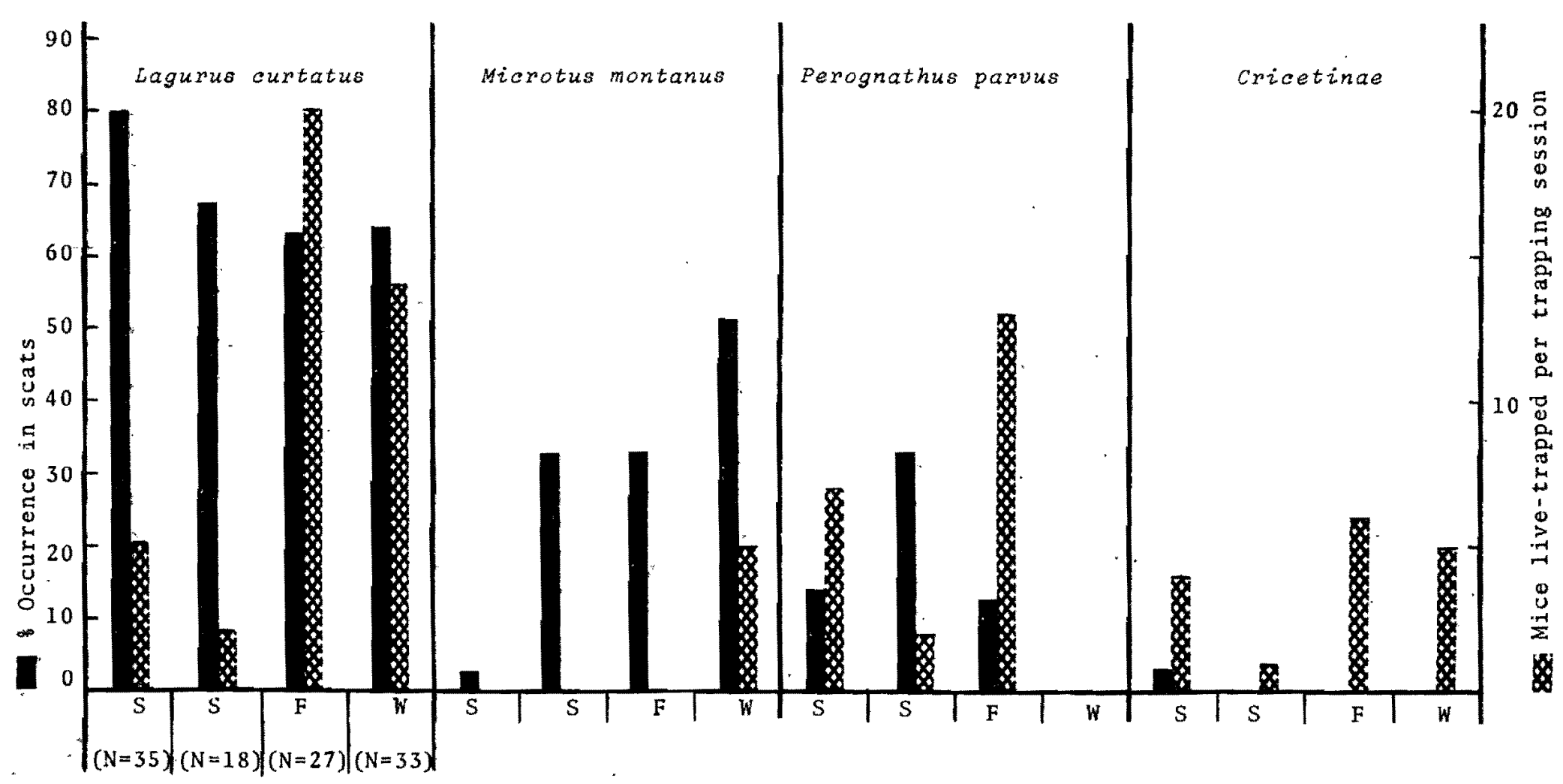

Figure 10. Comparison of numbers of small mammals live-trapped with small mammals in coyote scatsRattlesnake Hills, Snively Road 1975. (Trapping data J. D. Hedlund, K. A. Gano, D. T. McCullogh, unpubl ished). 
Basin grids showed the expected pattern of pocket mouse activity -- active during the spring, summer and fall but none in winter. However, fluctuations in trapping rates showed no relationship to changes in scat occurrence during the active period (Fig, 10).

Microtus montanus occurred frequently in coyote scats for an average seasonal occurrence of 32 percent, second only to Lagurus. In constrast to its abundance in scats, Microtus was only trapped during the winter (February 1976) at the 533 meter leve1. Cricetines (Peromyscus manicuzatus) were trapped in small numbers during all seasons of the year but occurred in only three out of 130 scats (two of these in trace amounts only).

Table $V$ shows that Lagurus is the most frequently trapped and the most frequently occurring mammal in the coyote's diet in the Rattlesnake Hills. Microtus, which was trapped only one month, must also have been plentiful somewhere in the Snively Canyon. Perognathus and Peromyscus were both frequently trapped, but only Perognathus occurred frequently in coyote scats. Other authors (Fichter, et al 1955; A. Murie, 1940; Scott 1947) have also reported that Peromyscus does not appear in canid diets as frequently as their numbers in the environment would lead one to expect. The explanation given is that Peromyscus is both nocturnal and secretive while voles are active at all hours (Ambrose 1973, Pearson 1960) and consistently follow 


\section{TABLE V}

COMPARISON OF THE TOTAL NUMBER OF EACH SPECIES

TRAPPED AND THE AVERAGE 1975 SEASONAL PERCENT

OCCURRENCE IN THE RATTLESNAKE HILLS

Lagurus Microtus Perognathus Peromysous

Number of

Individuais

Trapped

56

5

29

21

Percent

Occurrence

in Scats

66

32

15

1 
poorly hidden runways (Pearson 1960). Thus, coyotes would more rarely encounter Peromyscus than voles. Perognathus is also strictly nocturnal (Kritzman 1974) but is eaten very frequently by coyotes. How the behavior of pocket mice make them more susceptible to coyote predation is not clear.

There is also evidence that Peromyscus is rejected by canids on the basis of taste. Steve Hoffman (Utah State University, unpublished data) reports that in captive feeding experiments coyotes did not eat Peromyscus as readily as other species including Perognathus, Spermophilus, and voles. Scott (1947) reports that he found Peromyscus killed by red foxes and left uneaten along trails and at dens. Rabbits occurred in only a few scats in the Rattlesnake Hills with an average for the year of 9 percent occurrence. Pocket gophers were the third most common mammal food, occurring in 25 percent of the scats. Other food items, all found at low occurrence, were ground squirrels (2 percent), a bushy-tailed wood rat (Neotoma cinerea, one scat), canid (trace), deer ( 2 percent), cattle ( 1 percent), birds (13 percent occurrence for the year, largely galliforms), darkling beetles, acridids, fruit ( 1 percent), and grass (see Appendix $C$ ). 
CHAPTER V

\section{DISTRIBUTION OF SCATS ON THE COLLECTION TRANSECTS}

Scats collected along the three principal collection routes do not appear to be distributed evenly but instead are clustered in some areas of the transect. Figures 11, 12 , and 13 chart the number of scats collected in each 0.1 mile interval on the Army Loop Road, the Gate 111 Road, and Snively Road. Each 0.5 mile interval on the ALR transect and each 0.2 mile interval on the Snively and Gate 111 Roads were treated as sample quadrats for statistical analysis of the scat distribution patterns. Using the $X^{2}$ goodness of fit test (Sokal and Rohlf 1969) the distribution of the numbers of scats collected in these quadrats differed significantly from randomness on all three transects $(P L .001)$. Each monthly sample on the ALR also differed significantly from a random distribution $(P \perp .005)$ except for the months of July 1974, and April, October, and November 1975.

The non-random distribution is not only statistically significant for most months but the consistent clustering of scats on certain sections of the transect can be clearly seen in Figure 11: The coyotes use a "latrine" area on the ALR marked by a much higher concentration of scats between 
Figure 11. Monthly distribution of coyote scats on the Army Loop Road, 1974-76, and coyote visits to scent posts 1974 and 1975 . 


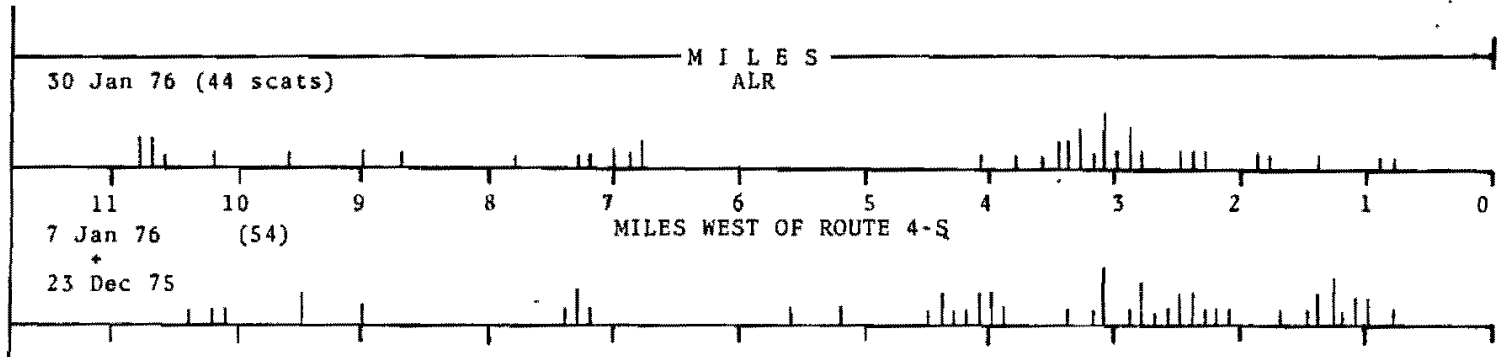

15 Nov $75 \quad$ (26)

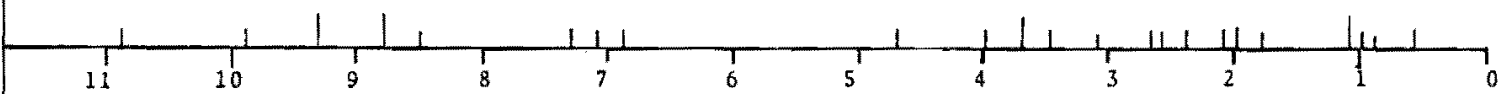

18 oct $75 \quad(46)$

Sept 75 (42)

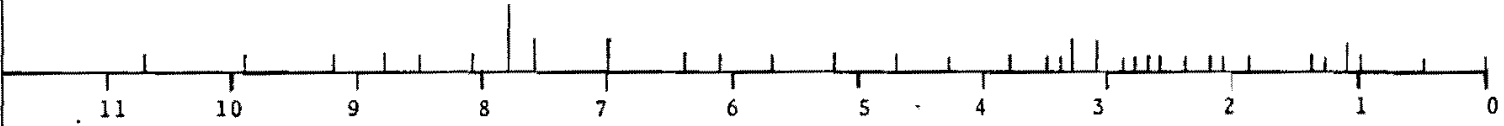

19 Aug 75 (51)

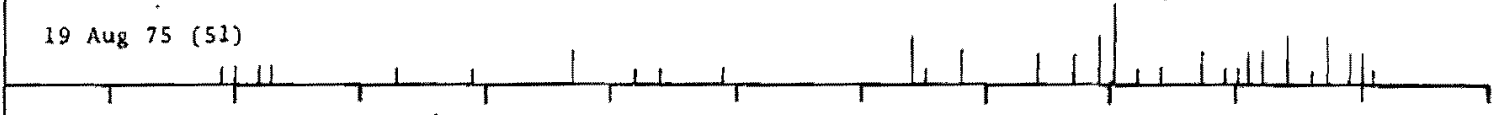

23 July 75 (30)

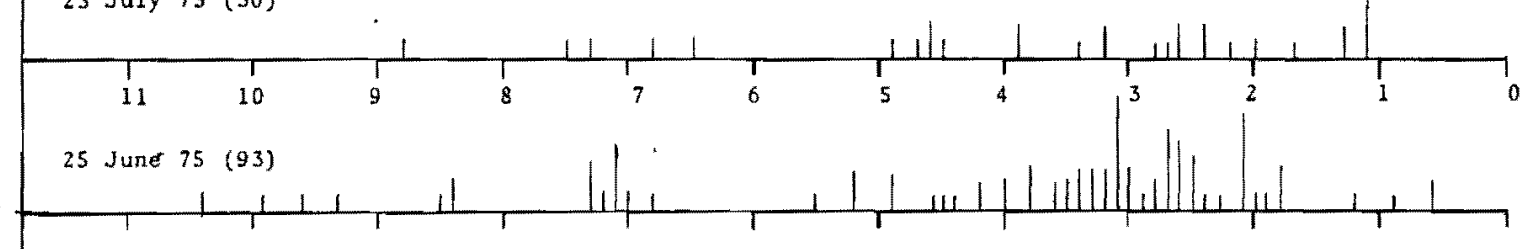

3. May 75 (57)

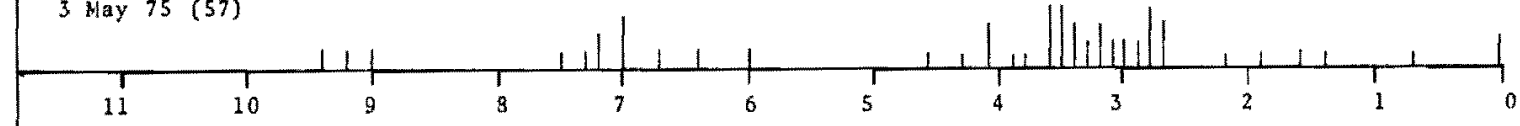

5 April 75 (38) 


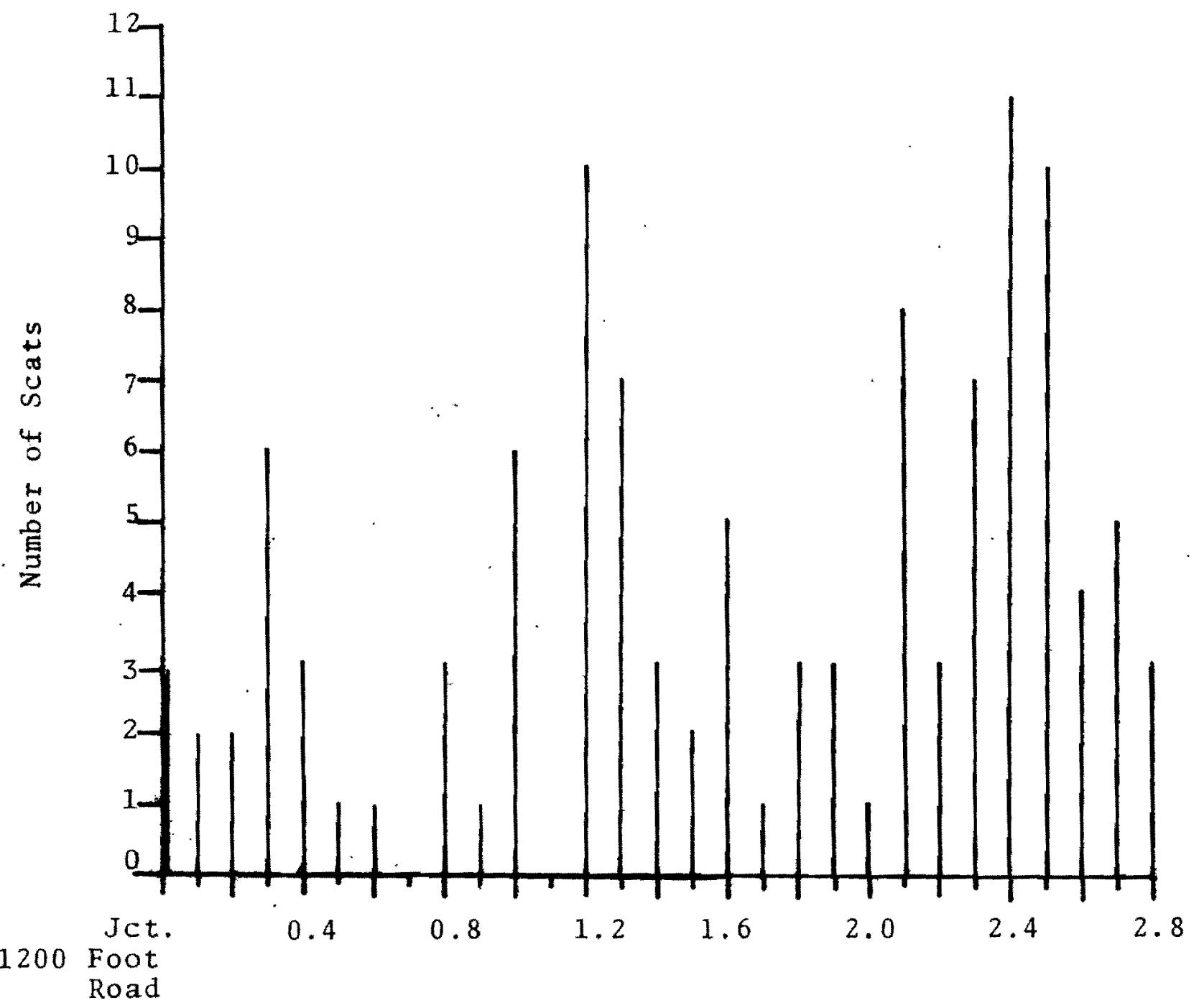

Figure 12. Distribution of coyote scats on Snively Road, 1975.

$\stackrel{\omega}{\leftarrow}$ 


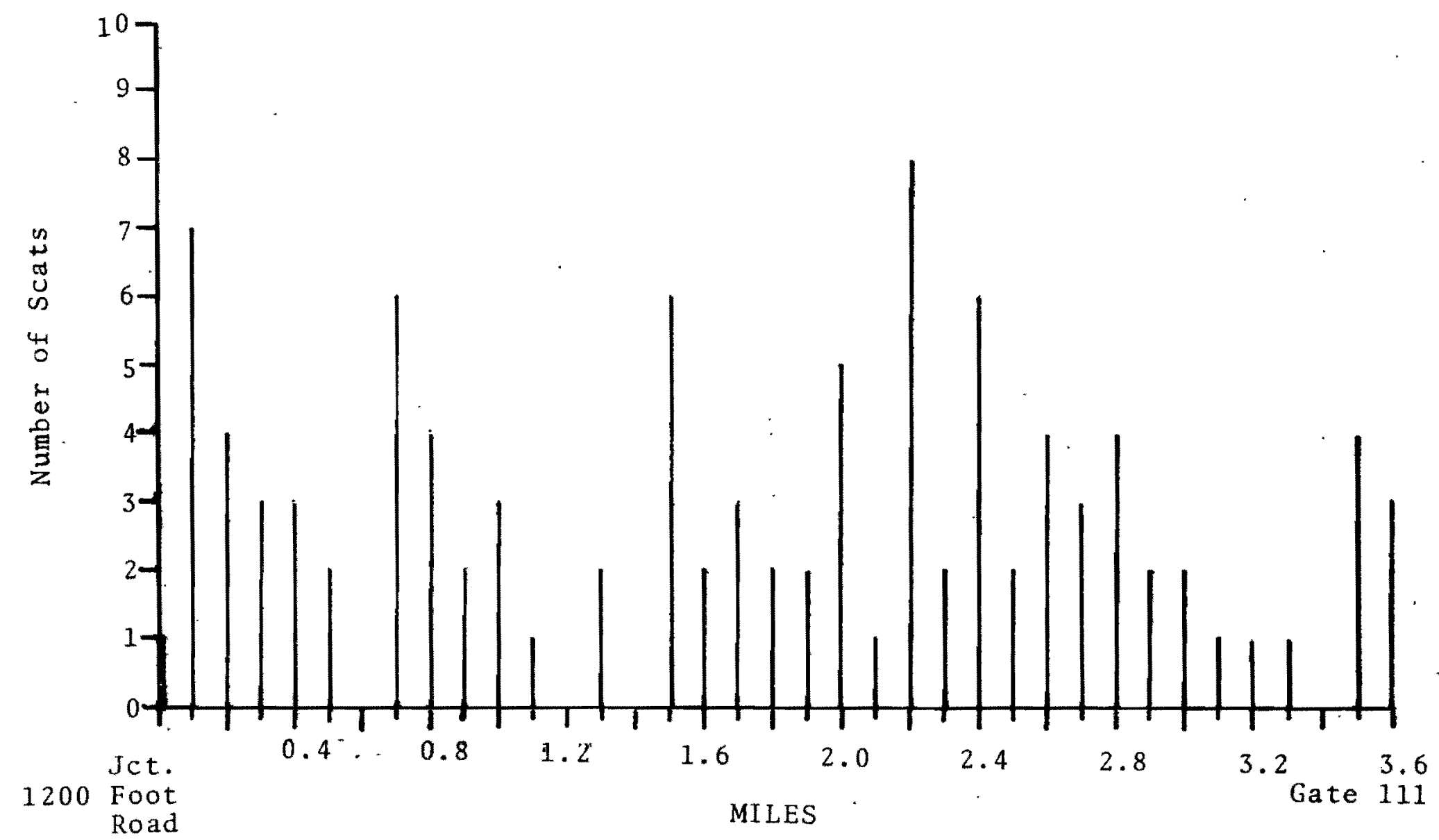

Figure 13. Distribution of coyote scats on Gate 111 Road, 1975 . 
2.2 and 3.6 miles. This area was consistently used through 1975 .

A partial explanation for these concentrations is offered by the observation of Ozoga and Harger (1966), who found that coyote droppings were concentrated on elevated spots such as small knolls, ridges, and beaver lodges. The ALR is built up above the surrounding terrain in many places, and this elevation may be part of the reason scats accumulate on this road. Other authors do not note any observations of clustering along roads, though many other coyote food habit studies also use droppings collected from roads. Thompson (1952) writes that "...my field experience with coyotes in wisconsin indicates that they do not concentrate their droppings on favored stretches of trail or road, at least not to the extent observed on...wolf runs." Since the heavy clustering is only in a few, not unusually elevated places on the ALR, the elevation is only part of the explanation. Mech and Frenzel (1971) and Peters (1975) note that a high proportion of sign on road and trails are found at junctions. However, scat clusters on the ALR are not well aligned with road junctions. Animal trail junctions with the ALR were not detected.

Peters (1975), in his extensive study of scent-marking in wolves, found that raised-1eg urinations (RLUs) in the snow were significantly more dense around the periphery of wolf pack territories. He presented much evidence showing 
that the RLUs functioned as territorial markers. Scats, on the other hand, were more ambiguous since they were more évenly distributed and were not primarily territorial markers; instead they were eliminative in function, he said. However, when scats accumulated in an area such as at road or trail junctions or at strategic points around "rendezvous sites" they were important markers, he suggested.

The simplest explanation for the clustering of scats more heavily on some sections of the ALR than others is that coyotes more frequently travel on or across those sections for unknown reasons. Coyotes drop scats there initially because it is elevated slightly above the surrounding land. Once droppings begin to accumulate the persistent smell on the road stimulates the same coyote or coyotes to defecate there again when they pass that way later. Peters (1975) noted that when the radio-tagged wolves he was studying travelled a second time over the same route which they had recently travelled they stopped to urinate again at the same spots they had stopped at earlier, even though the markings were all their own. If coyotes behave similarly scats would accumulate rapidly in such areas. An observation by Adolph Murie (1936) indicates that other canids behave similarly to wolves in this respect.

"Droppings are left in all kinds of situations both on and off trails... Certain stretches of trail, perhaps because more frequently travelled by foxes, were especially productive. One dropping seems to suggest another so that sometimes five or six 
droppings are found to occur together. In the west I have seen as many as thirty or forty

coyote droppings. in a favorable location."

(p. 30)

It is logical to think that the location of these

scat areas are not arbitary but instead are related to significant places in the coyotes' world such as rendezvous sites, den areas, food caches or territorial boundaries. However, this remains to be shown for coyote scat areas in general as well as for these areas on the ALR in particular. 


\section{SUMMARY}

Coyote food habits on USERDA's Hanford Reservation in south-central Washington were studied by analyzing 1152 scats collected during the spring of 1974 and every month in 1975. The coyote's diet was distinctly different in two habitats on the Reservation. On the lowland plain making up most of the Reservation the two principal foods of the coyote in 1975 were Great Basin pocket mice Perognathus parvus (60 percent average monthly occurrence) and leporids Lepus americanus and sylvilagus nuttalii (39 percent). pocket mice and leporids occurred in every monthly sample of 1974-76. Other food items included pocket gophers (12 percent average monthly occurrence), cricetine mice ( 7 percent), microtine mice ( 3 ), ground squirrels (4.5), grasshoppers (12) darkling beetles (6), birds (5), reptiles (4), fruit (10), and livestock (2).

Sharp fluctuations in the seasonal occurrence of these items and coactions between them are discussed. Occurrence of mice in coyote scats followed closely the rate at which mice were caught in live traps on a low elevation small trapping grid.

At higher elevations in the Rattlesnake Hills the coyote's diet was heavily dominated during all seasons by 
microtine mice which were uncommon at low elevation--Lagurus curtatus ( 66 percent), and Microtus montanus (32 percent), from an analysis of 102 scats. The rate at which rodents were trapped at the higher elevation trapping grid was not correlated with changes in their occurrence in coyote scats. Overall Lagurus was highest in numbers trapped, but Microtus, Perognathus, and Peromyscus were not trapped in the same relative abundance as theyarefound incoyote scats, possibly due to the heterogeneous environment in the Snively Basin which varied in flora and fauna only short distances from the trapping grids. Besides microtines, food items included Perognathus parvus (15 percent average seasonal occurrence), Peromyscus maniculatus ( 1 percent), leporid (9), pocket gopher (25), Spermophilus townsendii (2), birds (13), and single occurrences or trace amounts of Neotoma cinerea, canid, deer, cattle, darkling beetle, grasshopper, fruit, and grass.

The coyote's food habits varied widely not only in different habitats but also within the same area in different seasons. Coyote food habits are very much a local ecological phenomenon. Since coyotes are wide-ranging, omnivorous, scavenging, "vacuum-cleaners", analysis of their scats can provide valuable, additional, data on the relative abundance of a variety of animals in an area. An example is the unusual abundance of microtines in the coyote's diet in the Rattlesnake Hills in 1975 compared to their 
abundance as reflected in small mammal trapping data. Coyote scats were significantly non-random in their distribution on the three collection transects (Chi square goodness-of-fit test $p<.001)$. Reasons discussed to explain the clustered pattern include a territorial marking function for the droppings as well as elimination, preference for elevated places for marking, previous droppings as stimulus to defecate in the same spot again, and juxtaposition of the scat concentrations to a number of significant places in the coyote's world. 


\section{REFERENCES CITED}

Ambrose, H. W. 1973. An experimental study of same factors affecting the spatial and temporal activity of Miorotus pennsyzvannious. J. Mammal. 54: 79-110.

Burrows, R. 1968. Wild Fox. N. Y. Taplinger Pub Co.

Clark, F. W. 1972. 'Influence of jackrabbit density on coyote population changes. J. Wildl. Mgmt. 36 (2) 343-356

Daubenmire, R. 1970. Steppe vegetation of Washington. Washington Agr. Exp. Sta. Tech. Bull. 62, Wash. State U., Pullman, Wh.

Ellis, R. J. 1959. Food habits and control of coyotes in N. Central Oklahoma. Okla. State U. Publ 56(2): 1-31.

Ferrel, C. M., H. R. Ieach, and D. F. Tillatson. 1953. Food habits of the coyote in California. Calif. Fish and Game 39: 301-341.

Fichter, E., et al. 1955. Some feeding patterns of coyotes in Nebraska. Ecol. Monogr. 25: 1-37.

Gier, H. T. 1968. Coyotes in Kansas. Agr. Expt. Sta. Bull. 393, Kansas State U., Manhattan, KS.

Glass, B. P. 1951. A key to skulls of North American mamals. Zool. Dept., Oklahoma State U., Stillwater, Ok.

Gross, J. E., I. C. Stoddart, and F. H. Wagner. 1974. Demographic analysis of a northern Utah jackrabbit population. Wildl. Monogr. 40.

Hedlund, J. D., D. T. MoCullugh, K. A. Gano. 1976a. Live weights of pocket mice from different habitats on the Hanford Reservation. Battelle PNWL Ann. Rep. to USERDA 1975, BNWL-2000, Pt. 2: 204-205, Battelle-PNWL, Richland, Wa.

Hedlund, J. D., W. H. Rickard, D. T. McCullugh, and K. A. Gano. 1976b. Response of pocket mice and ground squirrel populations to wildfire. Battelle PNWL Ann. Rep. to USERDA 1975, Battelle PNWL, Richland, Wa. 
Hedlund, J. D. and L. E. Rodgers. 1976. Characterization of small mammal populations inhabitating the B-C Crib environs. BNWL-2181, Battella Pacific Northwest Laboratories, Richland, Wa.

Hinds, W. T. and J. M. Thorp. 1974. Climatology of the Arid Lands Ecology Reserve. Battelle PNW Laboratories Ann. Rep. to USAEC

1973. BNWI-1850, Pt. 2: 141-143, Battelle PNWL, Richland, Wa.

Ingles, L. C. 1965. Mammals of the Pacific States. Stanford University Press, Stanford, CA.

Knowlton, F. F. 1964. Aspects of coyote predation in S. Texas with special reference to the white-tailed deer. PH.D Thesis, Purdue u.

Korschgen, L. J. 1969. Procedures for food habits analysis. (Chapter 15 in Wildlife Management Techniques. The Wildl. Society, Washington, D. C., pp. 233-250.)

Kritzman, E. B. 1974. Ecological relationships of Peromyscus maniculatus and Perognathus parvus in E. Washington. J. Mammal. 55: 172-188.

Macclintock, D. and W. Ferguson. 1970. Squirrels of North America. Von Nostrand Reinhold, N.Y.

Mayer, W. V. 1952. The hair of Calif. mammals with keys to the dorsal guard hairs of Calif. mammals. Amer. Midl. Nat. $48(2)$ : $480-514$.

Mech, L. D. and L. D. Frenzel (eds.). 1971. Ecological, studies of the timber wolf in N. E. Minn. U.S. Forest Service. N. Central Forest Expt. Sta. Res. Paper NC-52, St Paul, MN.

Meinzer, W. P. , D. N. Ueckert, J. F. Flinders. 1975. Foodniche of coyotes in the rolling plains of Texas. J. or Range Mgmt. $28: 22-27$.

Moore, T. D. 1974. Identification of the dorsal guard hairs of some mammals in Wyoming. Wyo. Game and Fish Dept., Bull. \#14.

Murie, A. 1936. Following fox trails. U. Mich. Museum Zool. Misc. Publ. 32.

Murie, A. 1940. Ecology of the coyote in the Yellowstone. Fauna of the National Parks of the U. S. Bull. No. 4. 
Murie, O. J. 1935. Food habits of the coyote in Jackson Hole, Wyaming. U. S. D. A. Circular No. 362 .

O'Farrell, T. P. 1972. Ecological distribution of sagebrush voles. Lagurus curtatus, in south-central Washington. J. Marmal. 53:632-636.

O'Farrell, T. P. 1975a. Small mammals, their parasites and pathologic lesions on the Arid Lands Ecology Reserve. Benton Co., Washington. Am. Midl. Nat. 93(2): 377-387.

O'Farrell, T. P. 1975b. Seasonal and altitudinal variations in populations of small manmals on Rattlesnake Mountain. Am. Midl. Nat. 94:190-204.

O'Farrell, T. P., J. D. Hedlund, R. A. Gies, and R. E. Fitzner. 1974. Small mammal studies on the ALE Reserve, 1972. Grassland Biame, U. S. Colorado State U., Fort Collins, Co.

O'Farrell, T. P., J. D. Hedlund, R. A. Gies, R. J. Olson, R. O. Gilbert. 1972. Small Mammal Studies on the AIE Reserve, 1971. Grassland Biome, U. S. International Biological Program Tech. Rep, 174. Colorado State U., Fort Collins, $C D$.

O'Farrell, T. P., R. J. Oisen, R. O. Gilbert, J. D. Hedlund. 1975. A population of Great Basin Pocket Mice, Perognathus parvus, in the shrub-steppe of south-central Washington. Ecol. Monogr. 45: 1-28.

Pzaga, J. J. and E. M. Harger. 1966. Winter activities and feeding habits of northern Michigan coyotes. J. Wildl. Mgt. $30(4): 809-818$.

Peters, R. P. and I. D. Mech. 1975. Scent-marking in wolves. Am. Scientist. $63(6): 628-637$.

Pearson, O. P. 1960. Habits of Microtus californiaus revealed by autamatic photograph records. Ecol Monogr. 30:231-249.

Rickard, W. H. 1970. The distribution of ground-dwelling bettles in relation to vegetation, season, and topography in the Rattlesnake Hills. Northwest Sci. 44:107-113.

Rickard, W. H. 1971. Observations on the distribution of Eleodes hispilabris (Say) in relation to elevation and termperature in the Rattlesnake Hills. Am. Midl. Nat. $85: 521-526$.

Rickard, W. H. 1972. Rattlesnake Hills Research Natural Area. In Federal Research Natural Areas in Oregon and Washington. $\overline{\mathrm{PNW}}$ Forest and Range Expt. Station, Portland, OR. Pp. RH-1 to $\mathrm{RH}-9$ + figures. 
Rodgers, L. E. and W. H. Rickard. 1975. A survey of darkling beetles in desert steppe vegetation after a decade. Entomol. Soc. Annals. $68(6)$ : 1069-1070.

Rodgers, L. E., J. K. Sheldon, N. E. Woodly, V. A. Uresk. 1976. Darkling beetle populations (Tenebrionidae) of the Hanford Reservation of south-central Washington. In Press, Battelle PNWL, Richland, WA.

Ryden, J. 1975. God's Dog. Coward, MoCann, \& Geoghegan.

Scott, T. G. 1947. Comparative analysis of red fox feeding trends on two central Iowa areas. Iowa State Coll. Agr. Exp. Sta Bull. 353: $427-487$.

Sheldon, J. K. and L. E. Rodgers. 1976. Grasshopper populations inhabiting the B-C Cribs and Redox Pond sites, 200 Area plateau, USERDA's Hanford Reservation. BNWL-1943, Battelle PNW Labs, Richland, WA.

Sokal, R. R. and F. J. Rohlf. 1969. Biometry. W. H. Freeman, San Francisco, CA.

Sperry, C. C. 1941. Food habits of the coyote. U. S. Dept of the Interior. Wildl. Res. Bull. 4. $70 \mathrm{pp}$.

Stoddart, L. Charles. 1972. Population ecology of northern Utah black-tailed jackrabbits. Ph.D. Thesis, Utah State Univ.

Thompson, D. Q. 1952. Travel, range, and food habits of timber wolves in Wisconsin. J. Marmal. 33: 429-442.

Wagner, F. H. and I. C. Stoddart. 1972. Influence of coyote predation on black-tailed jackrabbit populations in Utah. J. Wildl. Mgmt. 36: 329-342. 
APPENDIX A

COYOTE SCAT ANALYSIS

ARMY LOOP ROAD 
COYOTE SCAT ANALYSIS--USERDA HANFORD RESERVATION

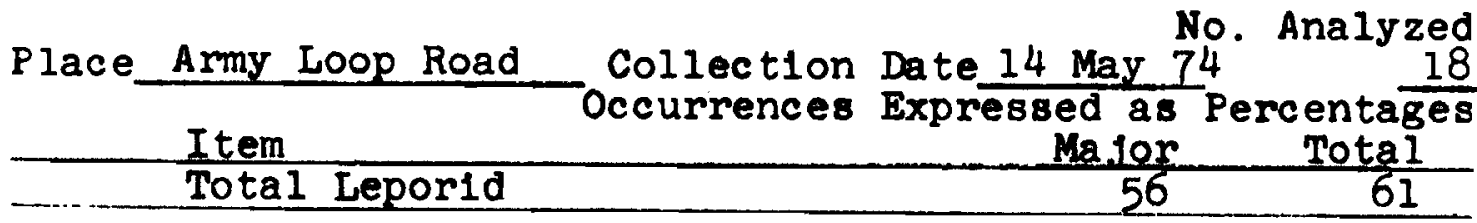

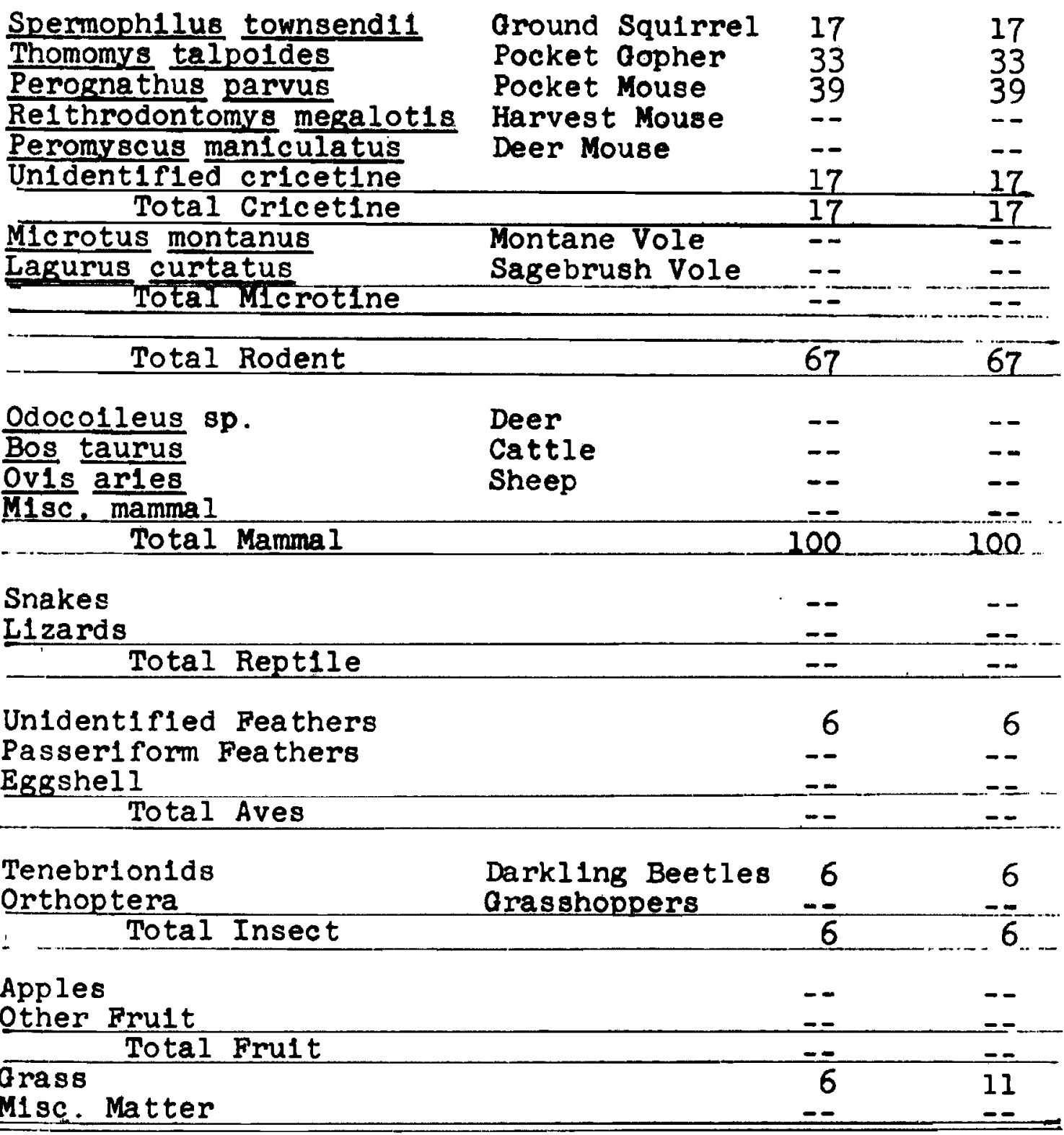


COYOTE SCAT ANALYSIS--USERDA HANPORD RESERVATION

Place Army Loop Road Collection Date 21 Jun 74 . Analyzed Occurrences Expressed as Percentages Item Total Lepor1d Major

\begin{tabular}{|c|c|c|c|}
\hline Total Leporid & & $\frac{300}{56}$ & $\frac{\text { Total }}{56}$ \\
\hline Spermoph1lus townsend11 & around Squirrel & & - \\
\hline Thomomys talpoldes & Pocket Gopher & 6 & 6 \\
\hline Perognathus parvus & Pocket Mouse & 19 & 19 \\
\hline Re1throdontomy megalotis & Harvest Mouse & - & -- \\
\hline$\frac{\text { Peromyscus }}{\text { Unidentified enlatus }}$ & Deer Mouse & -- & -- \\
\hline Total Cricetine & & -- & -- \\
\hline M1crotus montanus & Montane Vole & -- & $\overline{--}$ \\
\hline Lagurus curtatus & Sagebrush Vole & -- & - \\
\hline Total Microtine & & & \\
\hline
\end{tabular}
Total Rodent (1) 31 44

Odoco1leus 8p. Deer

Bos taurus

0v1s ar1es

1.3c, mammal Total Mamma 1

Cattle

Sheep

$\begin{array}{ll}-- & -- \\ -- & -- \\ -- & -- \\ 75 & 75\end{array}$

Snakes

L1zards

Total Rept1le

$-\overline{-} \quad--$

Unidentifled Feathers

Passeriform Feathers

Eggshell Total Aves

$\begin{array}{rr}6 & 12 \\ -- & -- \\ -6 & 12\end{array}$

Tenebrionids

Orthoptera Total Insect (2)

Darkling Beetles Grasshoppers

$\overline{87}$

$--$ 94 87 Apples

Other Fruit (3) arass Total Fruit

M1sc. Matter (4)

(1) Unldentified small rodents included

(2) Includes one occurrence of a clcada

(3) Plum

(4) Sand, small stones 
COYOTE SCAT ANALYSIS--USERDA HANBORD RESERVATION

No. Analyzed

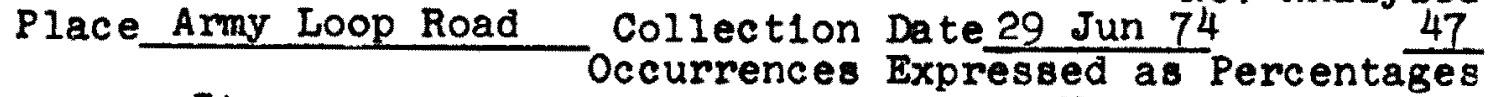
Item Total Lepor1d Major Total

\begin{tabular}{|c|c|c|c|}
\hline $\begin{array}{l}\text { Item } \\
\text { Total Leporid }\end{array}$ & & $\frac{10 r}{60}$ & $\frac{\text { Total }}{60}$ \\
\hline 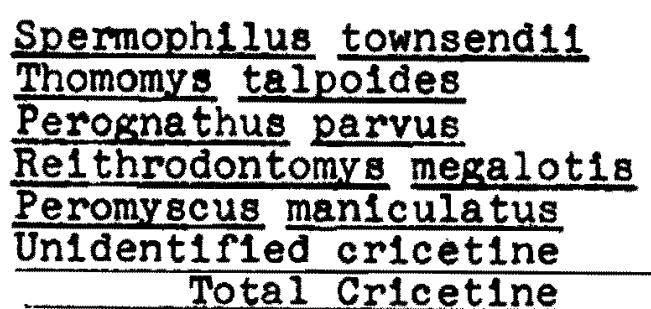 & $\begin{array}{l}\text { Ground Squirrel } \\
\text { Pocket Oopher } \\
\text { Pocket Mouse } \\
\text { Harvest Mouse } \\
\text { Deer Mouse }\end{array}$ & $\begin{array}{r}2 \\
-- \\
21 \\
-\frac{2}{2} \\
2 \\
4\end{array}$ & $\begin{array}{r}2 \\
-- \\
21 \\
-- \\
2 \\
\frac{2}{4} \\
\end{array}$ \\
\hline Microtus montanus & $\begin{array}{l}\text { Montane Vole } \\
\text { Sagebrush Vole }\end{array}$ & $\begin{array}{l}4 \\
-- \\
--\end{array}$ & $\begin{array}{l}4 \\
-- \\
--\end{array}$ \\
\hline Total Microtine & & -- & -- \\
\hline Total Rodent (1) & & 26 & 28 \\
\hline$\frac{\text { Odocolleus }}{\text { Bos }}$ sp. & $\begin{array}{l}\text { Deer } \\
\text { Cattle } \\
\text { Sheep }\end{array}$ & $\begin{array}{l}-- \\
-- \\
--\end{array}$ & $\begin{array}{l}-- \\
-- \\
=-\end{array}$ \\
\hline Total Mammal & & 74 & 77 \\
\hline $\begin{array}{l}\text { Snakes } \\
\text { Ilzards }\end{array}$ & & $=$ & 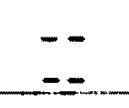 \\
\hline Total Reptile & & -- & -- \\
\hline $\begin{array}{l}\text { Unldentifled Fea thers } \\
\text { Passer1 form Feathers } \\
\text { Eggshell }\end{array}$ & & $\begin{array}{l}2 \\
-- \\
=-\end{array}$ & 13 \\
\hline Total Aves & & 2 & 13 \\
\hline $\begin{array}{l}\text { Tenebrionids } \\
\text { Orthoptera } \\
\text { Total Insect } \\
\end{array}$ & $\begin{array}{l}\text { Darkl1ng Beetles } \\
\text { Grasshoppers }\end{array}$ & $\frac{--}{53}$ & $\begin{array}{r}2 \\
74 \\
77 \\
\end{array}$ \\
\hline $\begin{array}{l}\text { Apples } \\
\text { Other Frult } \\
\text { Total Fruit }\end{array}$ & & $\begin{array}{ll}-- \\
--\end{array}$ & $\overline{-}$ \\
\hline $\begin{array}{l}\text { Mrass } \\
\text { Misc. Matter (2) }\end{array}$ & & $\begin{array}{r}4 \\
-- \\
\end{array}$ & $\begin{array}{r}26 \\
2 \\
\end{array}$ \\
\hline
\end{tabular}

(1) Includes unidentified small rodent, one occurrence

(2) Unldent1fied materlal 
COYOTE SCAT ANALYSIS--USERDA HANFORD RESERVATION

Place Army Loop Road Collection Date $19 \mathrm{Jul} 74$. Analyzed

Item

Occurrences Expressed as Percentages

Total Lepor1d

Major

31

Total

Spermoph1lus townsend11

Thomomys talpoldes

Perognathus parvus

Re1 throdontomys megalot 18

Peromyscus man1culatus

Un1dentifled cricetine Total Cricetine

Lagurus curtatus Total MIcrotine

Ground Squirrel

Pocket Gopher

Pocket Mouse

Harvest Mouse

Deer Mouse

Montane Vole

Sagebrush Vole

\begin{tabular}{ll}
-- & -- \\
-- & -- \\
15 & 15 \\
-- & -- \\
-- & -- \\
-- & -- \\
-- & -- \\
\hline-- & -- \\
-- & - \\
\hline
\end{tabular}

Total Rodent

15

15

Odocolleus sp.

Bos taurus

Ov1s aries

18c. mammal

Total Mammal

Deer

Cattle

Sheep

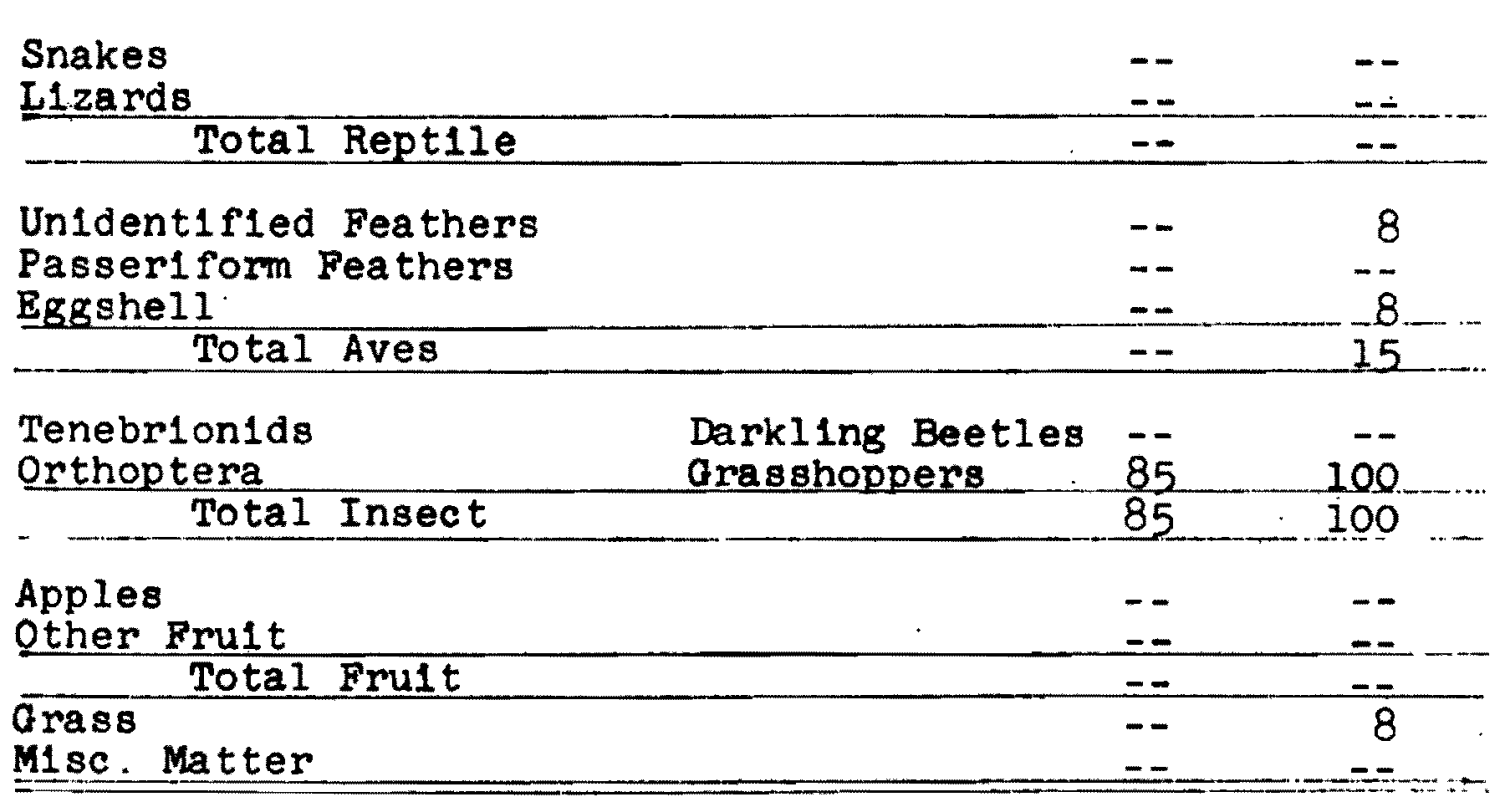


COYOTE SCAT ANALYSIS--USERDA HANFORD RESERVATION

Place Ary Analyzed Army Loop Read Occurrences Expressed as Percentages Item Total Leporid Major 21 Total

\begin{tabular}{crr} 
Item & Major & Total \\
\hline Total Leporid & 21 & 24
\end{tabular}

Spermoph1lus townsend11 Thomomys talpoldes Perognathus parvus Re1 throdontomys megalotis Peromyscus maniculatus Unidentified cricetine Microtus montanus Lagurus curtatus Ground Squirrel Pocket Gopher Pocket Mouse Harvest Mouse Deer Mouse Total Microtine

Montane Vole Sagebrush Vole

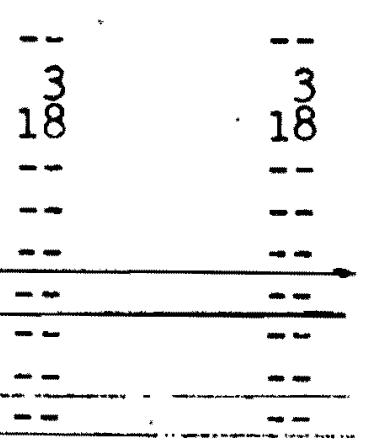

Total Rodent (2) 24 24

Odocolleus sp.

Bos taurus

Ov1s aries

Deer

Cattle

Sheep

M1sc, mammal Total Mammal

(3)

Snakes

Lizards Total Reptile

Unidentifled Feathers Passeriform Feathers

Eggshel1 Total Aves

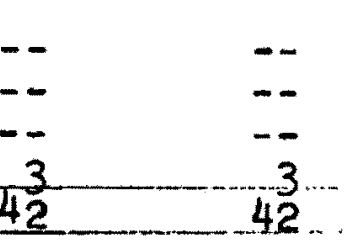

42

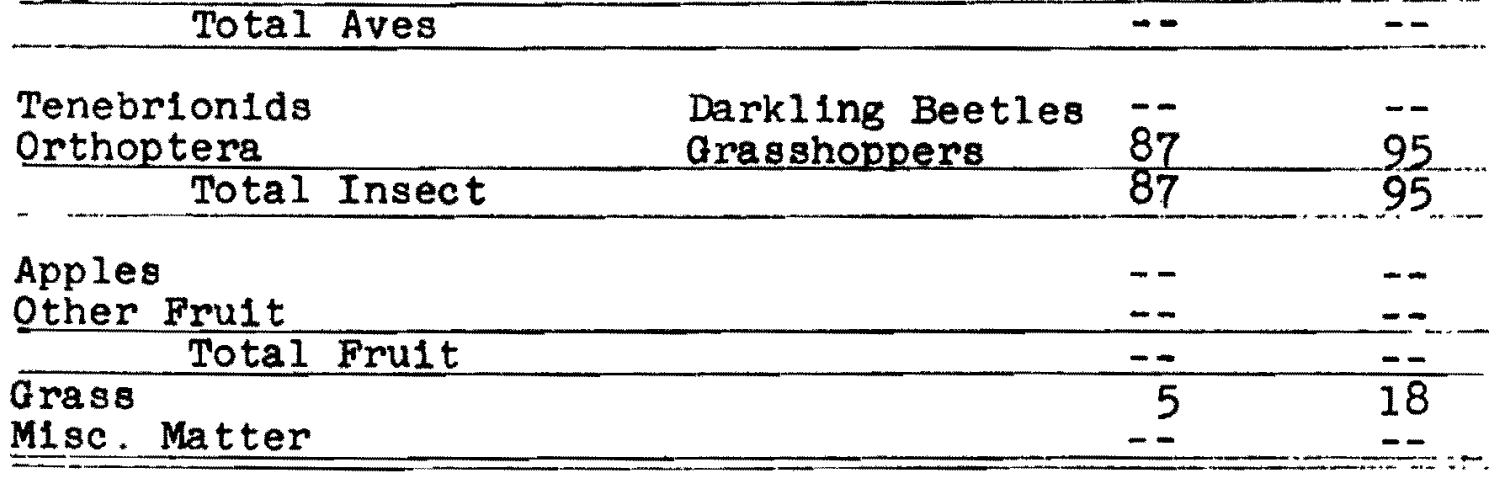

(1) Collection dates--Jul 30 (7 scats), Jul 31 (17 scats), Aug 6 (14 scats).

(2) Includes two unidentifled-mouse occurrences

(3) Unidentifled hair 
COYOTE SCAT ANALYSIS--USERDA HANFORD RESERVATION

Place Amy Loop Road No. Analyzed

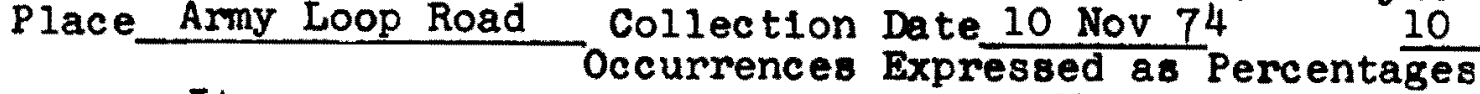
Item Total Leporid Najor Total

\begin{tabular}{cccc} 
Item & Major & Total \\
\hline Total Leporid & 40 & 40 \\
\hline
\end{tabular}

Spermoph1lus townsend11 Ground Squirrel Thomomys talpo1des Perognathus parvus Pocket Gopher $10 \quad 10$ Re1throdontomy megalot is Peromyscus maniculatus $\frac{\text { Unidentified cricetine }}{\text { Total Cricetine }}$ $\frac{\text { Unidentified cricetine }}{\text { Total Cricetine }}$ Microtus montanus Lagurus curtatus Total Microtine Pocket Mouse Harvest Mouse 50

Deer Mouse -- Montane Vole Sagebrush Vole

$$
\text { Total Rodent }
$$

Odocolleus sp.

Bos taurus

Ov1s aries

M1sc. mammaI

$$
\text { Total Mammal }
$$

\section{Snakes}

Lizards Total Rept1le

Deer Cattle

\begin{tabular}{|c|c|c|c|}
\hline Total Rept11e & & - & 10 \\
\hline $\begin{array}{l}\text { Unidentifled Feathers } \\
\text { Passeriform Feathers } \\
\text { Eggshell }\end{array}$ & & -- & $\begin{array}{l}-- \\
-- \\
--\end{array}$ \\
\hline Total Aves & & - & - \\
\hline $\begin{array}{l}\text { Tenebrionids } \\
\text { Orthoptera }\end{array}$ & $\begin{array}{l}\text { Darkl 1ng Beetles } \\
\text { arasshoppers }\end{array}$ & $\begin{array}{l}10 \\
20\end{array}$ & $\begin{array}{l}10 \\
30\end{array}$ \\
\hline Total Insect & & 20 & 30 \\
\hline $\begin{array}{l}\text { Apples } \\
\text { Other Fruit }\end{array}$ & & $\begin{array}{l}10 \\
--\end{array}$ & 10 \\
\hline Total Fruit & & 10 & 10 \\
\hline $\begin{array}{l}\text { Grass } \\
\text { Misc. Matter (1) }\end{array}$ & & 10 & 10 \\
\hline
\end{tabular}
Sheep

Deer
Cattle
Sheep

50

(1) Dirt 
COYOTE SCAT ANALYSIS--USERDA HANFORD RESERVATION

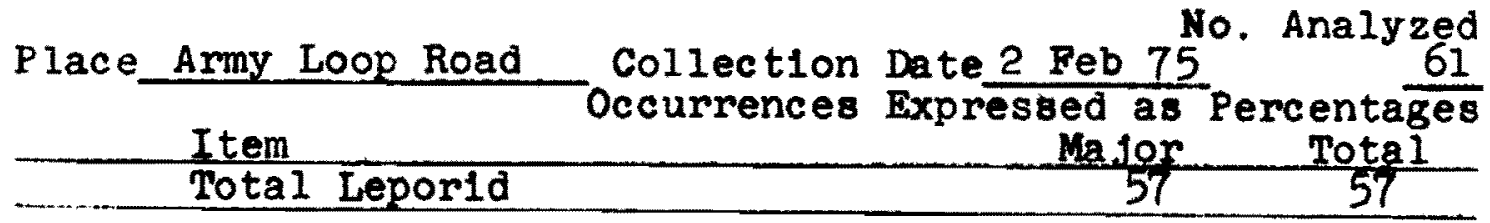

Spermoph1lus townsend11 Ground Squirrel 2 2

Thomomys talpoides

Perognathus parvus Pocket Oopher

7

Re1throdontomys megalot1s

Peromyscus maniculatus Pocket Mouse

Unldentified cricetine Total Cricetine Harvest Mouse

Deer Mouse $11 \quad 13$

810

icrotus montanus

Montane Vole

11

$7 \quad 13$

$23-31$

Lagurus curtatus

Sagebrush Vole Total Microtine Total Rodent 36

2

2

\begin{tabular}{|c|c|c|c|}
\hline Total Mlcrotine & & 2 & 2 \\
\hline Total Rodent & & 36 & 43 \\
\hline 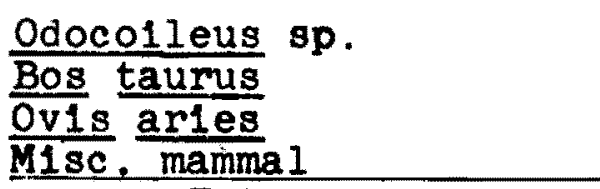 & $\begin{array}{l}\text { Deer } \\
\text { Cattle } \\
\text { Sheep }\end{array}$ & $\begin{array}{r}11 \\
-- \\
--\end{array}$ & $\begin{array}{r}-- \\
11 \\
-- \\
\end{array}$ \\
\hline Total Mamma I & & 90 & 90 \\
\hline $\begin{array}{l}\text { Snakes } \\
\text { L1zards }\end{array}$ & & $\begin{array}{l}2 \\
2 \\
2\end{array}$ & $\begin{array}{r}2 \\
2 \\
\end{array}$ \\
\hline Total Rept1le & & 3 & 3 \\
\hline $\begin{array}{l}\text { Unidentifled Fea thers } \\
\text { Passeriform Fea thers } \\
\text { Eggshell }\end{array}$ & & $\begin{array}{r}8 \\
2 \\
-- \\
\end{array}$ & $\begin{array}{l}8 \\
2\end{array}$ \\
\hline Total Aves & & 10 & 10 \\
\hline $\begin{array}{l}\text { Tenebrionids } \\
\text { Orthoptera }\end{array}$ & $\begin{array}{l}\text { Darkl1ng Beetles } \\
\text { Grasshoppers }\end{array}$ & -- & - \\
\hline Total Insect $(1\rangle$ & & $=-$ & 2 \\
\hline $\begin{array}{l}\text { Apples } \\
\text { other Fruit }\end{array}$ & & $\begin{array}{r}13 \\
5\end{array}$ & $1 \frac{13}{5}$ \\
\hline $\begin{array}{l}\text { Total Fruit } \\
\text { Mrass } \\
\text { Misc. Matter (2) }\end{array}$ & & $\frac{18}{3}$ & $\begin{array}{r}18 \\
26 \\
7\end{array}$ \\
\hline
\end{tabular}

(1) Unident1fled Insect 
COYOTE SCAT ANALYSIS--USERDA HANFORD RESERVATION

Place Army Loop Road Collection Date $14 \mathrm{Mar} 75$. Analyzed Occurrences Expressed as Percentages Item Total Lepor1d Major 54 Total

\begin{tabular}{|c|c|c|c|}
\hline $\begin{array}{l}\text { Item } \\
\text { Total Leporid }\end{array}$ & & $\frac{10 r}{54}$ & $\frac{\text { Total }}{54}$ \\
\hline 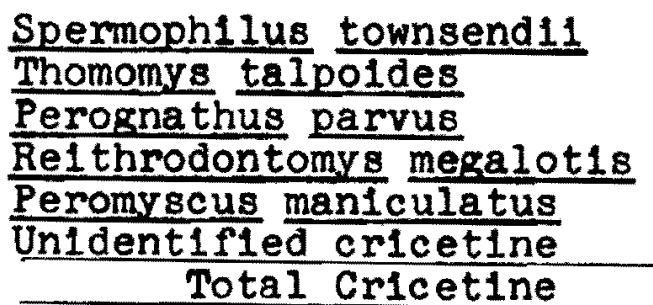 & $\begin{array}{l}\text { Ground Squirrel } \\
\text { Pocket Gopher } \\
\text { Pocket Mouse } \\
\text { Harvest Mouse } \\
\text { Deer Mouse }\end{array}$ & $\begin{array}{r}10 \\
25 \\
46 \\
2 \\
6 \\
-- \\
8\end{array}$ & $\begin{array}{r}10 \\
25 \\
50 \\
4 \\
8 \\
4 \\
17\end{array}$ \\
\hline $\begin{array}{l}\text { Microtus montanus } \\
\text { Lagurus curtatus } \\
\text { rotal Microtine }\end{array}$ & $\begin{array}{l}\text { Montane Vole } \\
\text { Sagebrush Vole }\end{array}$ & $-\overline{-}$ & $\frac{-1}{-2}$ \\
\hline Total Rodent & & 62 & 65 \\
\hline 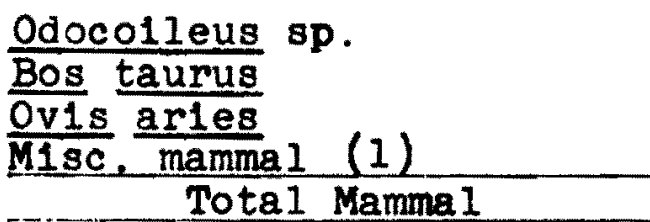 & $\begin{array}{l}\text { Deer } \\
\text { Cattle } \\
\text { Sheep }\end{array}$ & $\begin{array}{r}-\frac{-}{6} \\
-\frac{2}{94}\end{array}$ & $\frac{--}{6}$ \\
\hline $\begin{array}{l}\text { Snakes } \\
\text { Llzards } \\
\end{array}$ & & $\overline{-}$ & -- \\
\hline Total Rept11e & & -- & -- \\
\hline $\begin{array}{l}\text { Unidentifled Feathers } \\
\text { Passeriform Feathers } \\
\text { Eggshell } \\
\frac{\text { Total Aves }}{}\end{array}$ & & $\begin{array}{l}-- \\
-- \\
--\end{array}$ & $\begin{array}{l}-- \\
-- \\
-- \\
--\end{array}$ \\
\hline $\begin{array}{l}\text { Tenebrionids } \\
\text { Orthoptera } \\
\text { Total Insect }\end{array}$ & $\begin{array}{l}\text { Darkl1ng Beetles } \\
\text { arasshoppers }\end{array}$ & $\frac{2}{--}$ & $\frac{2}{2}$ \\
\hline $\begin{array}{l}\text { Apples } \\
\text { other Fruit }\end{array}$ & & -2 & $\begin{array}{r}2 \\
-- \\
\end{array}$ \\
\hline $\begin{array}{l}\text { Total Fruit } \\
\text { Grass } \\
\text { Misc. Matter }\end{array}$ & & $\begin{array}{r}2 \\
4 \\
-- \\
\end{array}$ & $\begin{array}{r}2 \\
29 \\
--\end{array}$ \\
\hline
\end{tabular}

(1). Unidentifled hair 
COYOTE SCAT ANALYSIS--USERDA HANPORD RESERVATION

Place Army Loop Road No. Analyzed

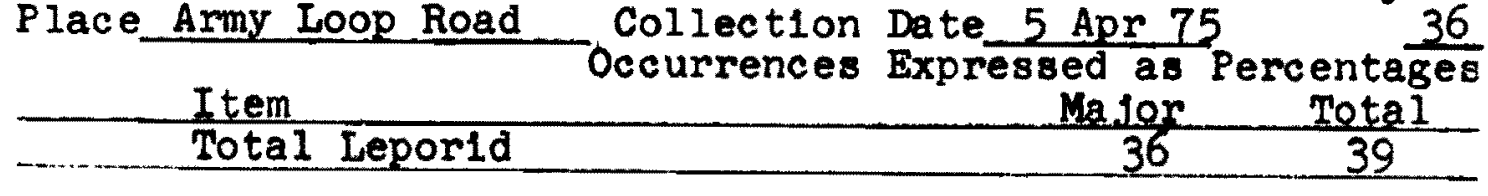

$\begin{array}{lllll}\text { Spermophilus townsendi1 } & \text { around Squirrel } & 8 & 8\end{array}$

Thomomys talpoldes

Perognathus parvus

Re1throdontomys megalot1s

Peromyscus maniculatus

Unidentifled cricetine Total Cricetine

Microtus montanus

Lagurus curtatus

Pocket Oopher

Pocket Mouse

Harvest Mouse

Deer Mouse

Total Microtine

Montane Vole

Sagebrush Vole

Total Rodent

89

$17 \quad 27$

$78 \quad 89$

$--$

3

$-$

3

$-$

Sagebrush vole

6

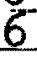

8

8

89

$\frac{3}{3}$

\begin{tabular}{|c|c|}
\hline $\begin{array}{l}\frac{\text { Odocolleus }}{\text { Bos }} \text { sp. } \\
\frac{\text { taurus }}{\text { Ov1s }} \\
\text { M1sc. } \frac{\text { arles }}{\text { mammal }}\end{array}$ & $\begin{array}{l}\text { Deer } \\
\text { Cattle } \\
\text { Sheep }\end{array}$ \\
\hline
\end{tabular}

Snakes

Lizards

Total Rept1le

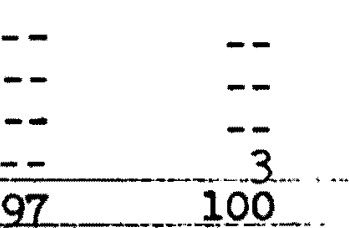

Unidentified Feathers

Passeriform Feathers

Eggshell

Total Aves

\begin{tabular}{ll}
-- & -- \\
-- & -- \\
-- & - \\
-- & -- \\
-- & -- \\
-- & $=-$ \\
\hline
\end{tabular}

Tenebrionids

Orthoptera Total Insect

Darkling Beetles Arasshoppers

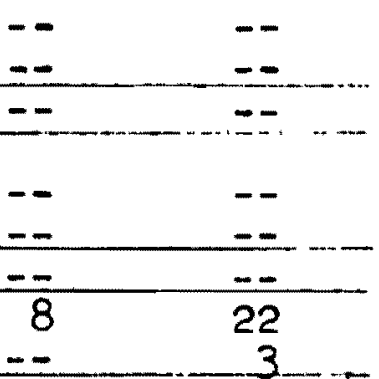

Apples

Other Fruit

arass Total Fruit

Misc. Matter (2)

(1) Unidentified hair

(2) Dirt 
COYOTE SCAT ANALYSIS--USERDA HANFORD RESERVATION

Place Army Loop Road Collection Date_3 May 75 . Analyzed

Item

Total Leporid

Occurrences Expressed as Percentages

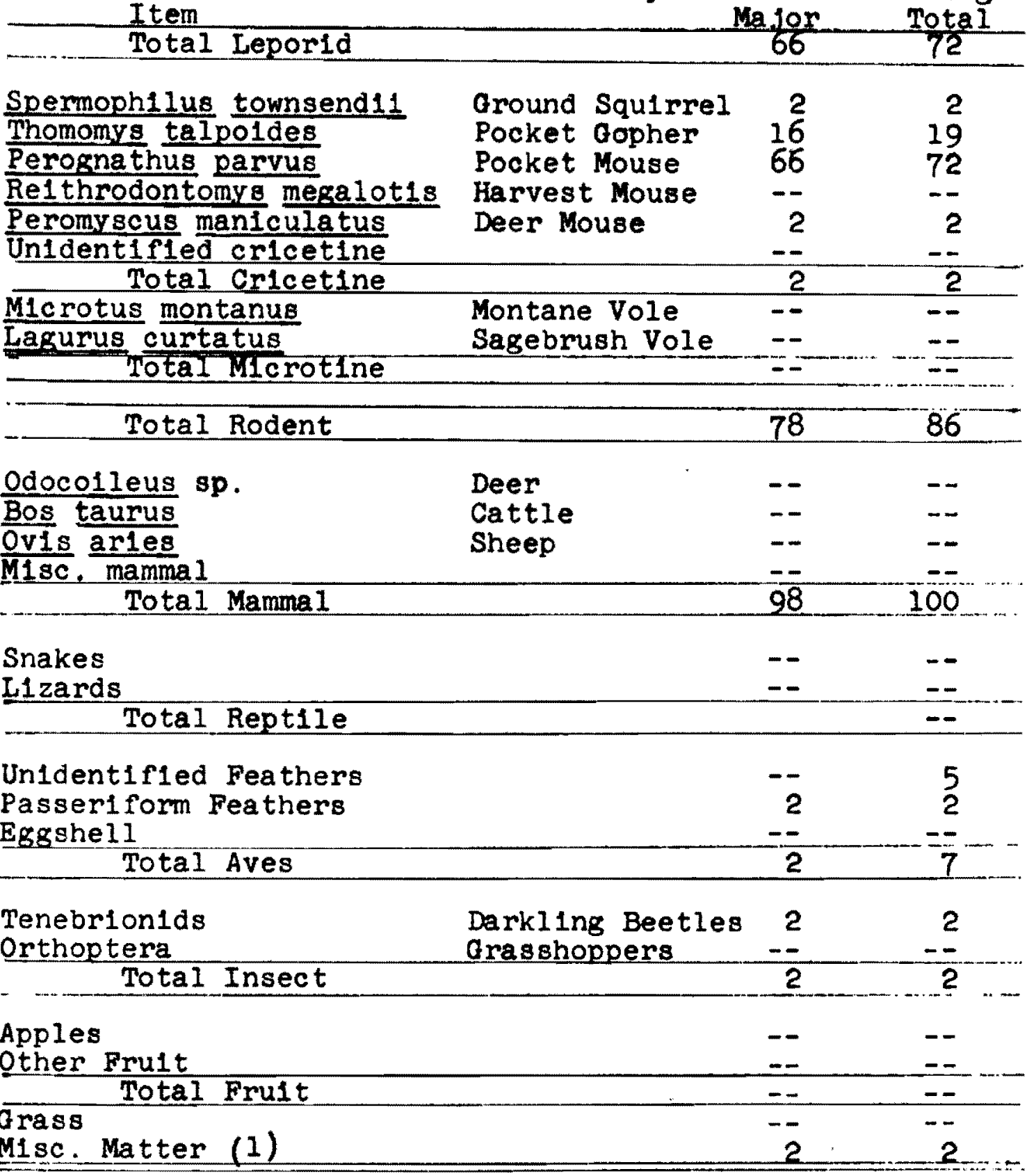

(1) Unidentifled flesh 
COYOTE SCAT ANALYSIS--USERDA HANFORD RESERVATION

Place Army Loop Rozd Collection Date 25 Jun No. Analyzed

Occurrences Expressed as Percentages Item Total Lepor1d Major Total

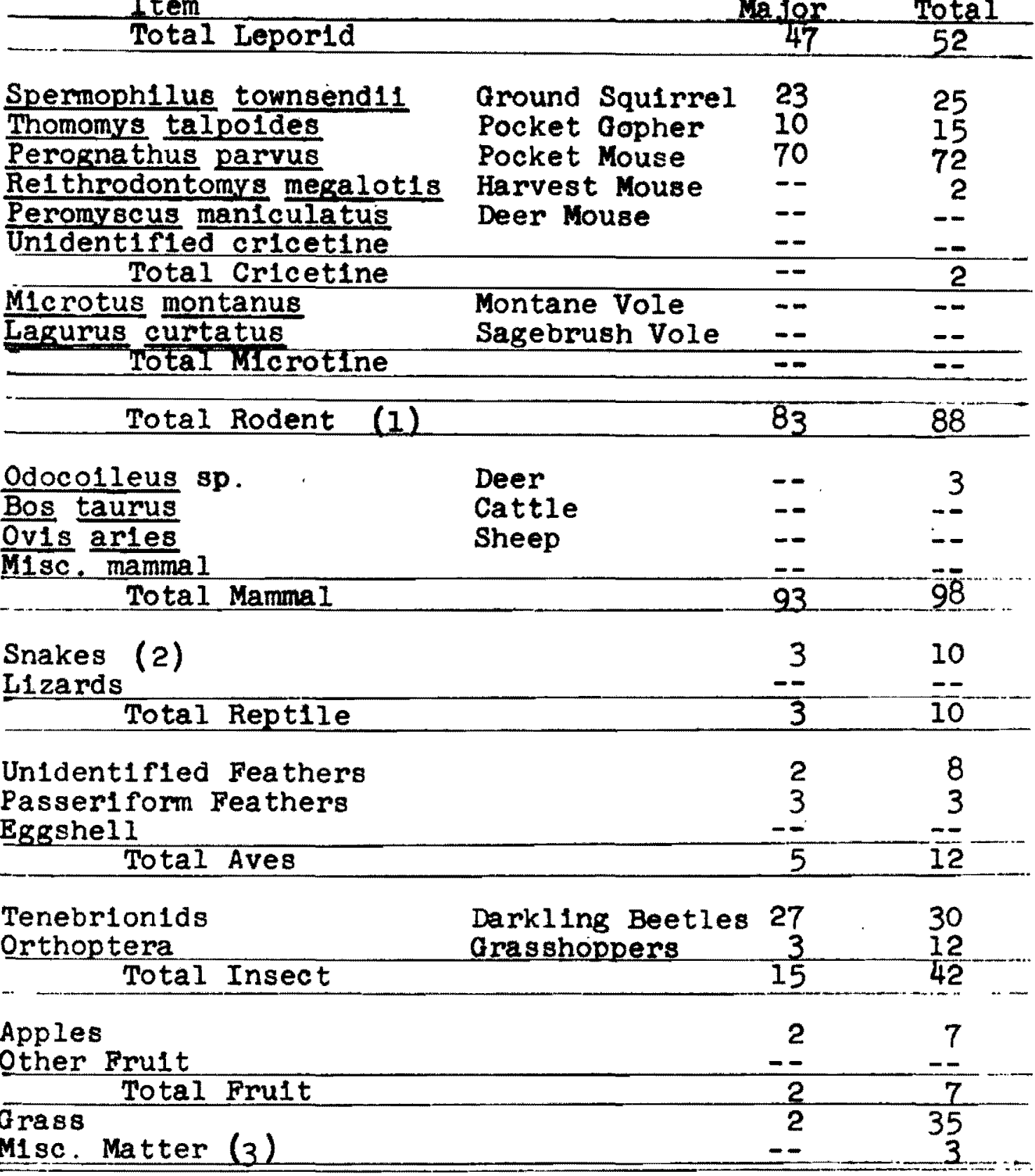
(1) Unidentifled mouse Included, one occurrence
(2) Western yellow-bellied racer, Coluber constrictor, one occurrence
(3) Paper, aluminum foll 
COYOTE SCAT ANALYSIS-USERDA HANPORD RESERVATION

Place_Army Loon Rord Collection Date 23 Jul 75 . Analyzed Item

Occurrences Expressed as Percentages

Total Leporid

Major

Total

Spermoph1lus townsend11

Thomomys talpoides

Perognathus parvus

Re1throdontomys megalotis

Peromyscus maniculatus

Unidentified cricetine

Total Cricetine

Microtus montanus

Lagurus curtatus

Total Mcrotine

Total Rodent

Ground Squirrel

Pocket Gopher

Pocket Mouse

Harvest Mouse

Deer Mouse

43
50

\begin{tabular}{|c|c|c|c|}
\hline Lagurus curtatus & Sagebrush vole & $=-$ & $=-$ \\
\hline Total Rodent & & 93 & 93 \\
\hline $\begin{array}{l}\frac{\text { Odocolleus }}{\text { Bos }} \text { sp. } \\
\frac{\text { taurus }}{\text { Ov1s }} \\
\text { M1sc. } \frac{\text { arles }}{\text { mamma } 1}\end{array}$ & $\begin{array}{l}\text { Deer } \\
\text { Cattle } \\
\text { Sheep }\end{array}$ & $\begin{array}{l}-- \\
-- \\
--\end{array}$ & $\begin{array}{l}-- \\
-- \\
-- \\
--\end{array}$ \\
\hline $\begin{array}{l}\text { Snakes } \\
\text { LIzards } \\
\qquad \text { Total Reptile }\end{array}$ & & $\begin{array}{l}20 \\
\frac{-1}{20}\end{array}$ & $\begin{array}{l}27 \\
\frac{27}{27}\end{array}$ \\
\hline $\begin{array}{l}\text { Unident1 fled Feathers } \\
\text { Passeriform Feathers } \\
\text { Eggshell } \\
\text { Total Aves }\end{array}$ & & $\begin{array}{r}7 \\
-7 \\
-13\end{array}$ & $\begin{array}{l}10 \\
10 \\
=- \\
20\end{array}$ \\
\hline $\begin{array}{l}\text { Tenebrionids } \\
\text { Orthoptera } \\
\text { Total Insect }\end{array}$ & $\begin{array}{l}\text { Darkl1ng Beetles } \\
\text { Grasshoppers }\end{array}$ & $\frac{--}{37}$ & $\frac{63}{63}$ \\
\hline $\begin{array}{l}\text { Apples } \\
\text { Other Fruit } \\
\text { Total Fruit }\end{array}$ & & $-\frac{7}{7}$ & $\begin{array}{l}\frac{10}{10} \\
\frac{10}{10}\end{array}$ \\
\hline $\begin{array}{l}\text { Grass } \\
\text { Misc. Matter }\end{array}$ & & $\begin{array}{r}7 \\
-- \\
\end{array}$ & 10 \\
\hline
\end{tabular}


COYOTE SCAT ANALYSIS--USERDA HANFORD RESERVATION

Pla. Analyzed

Place Army Loop Road Collection Date 19 Aug 75 An

Occurrences Expressed as Percentages Item

Total Lepor1d

Major

35 Total

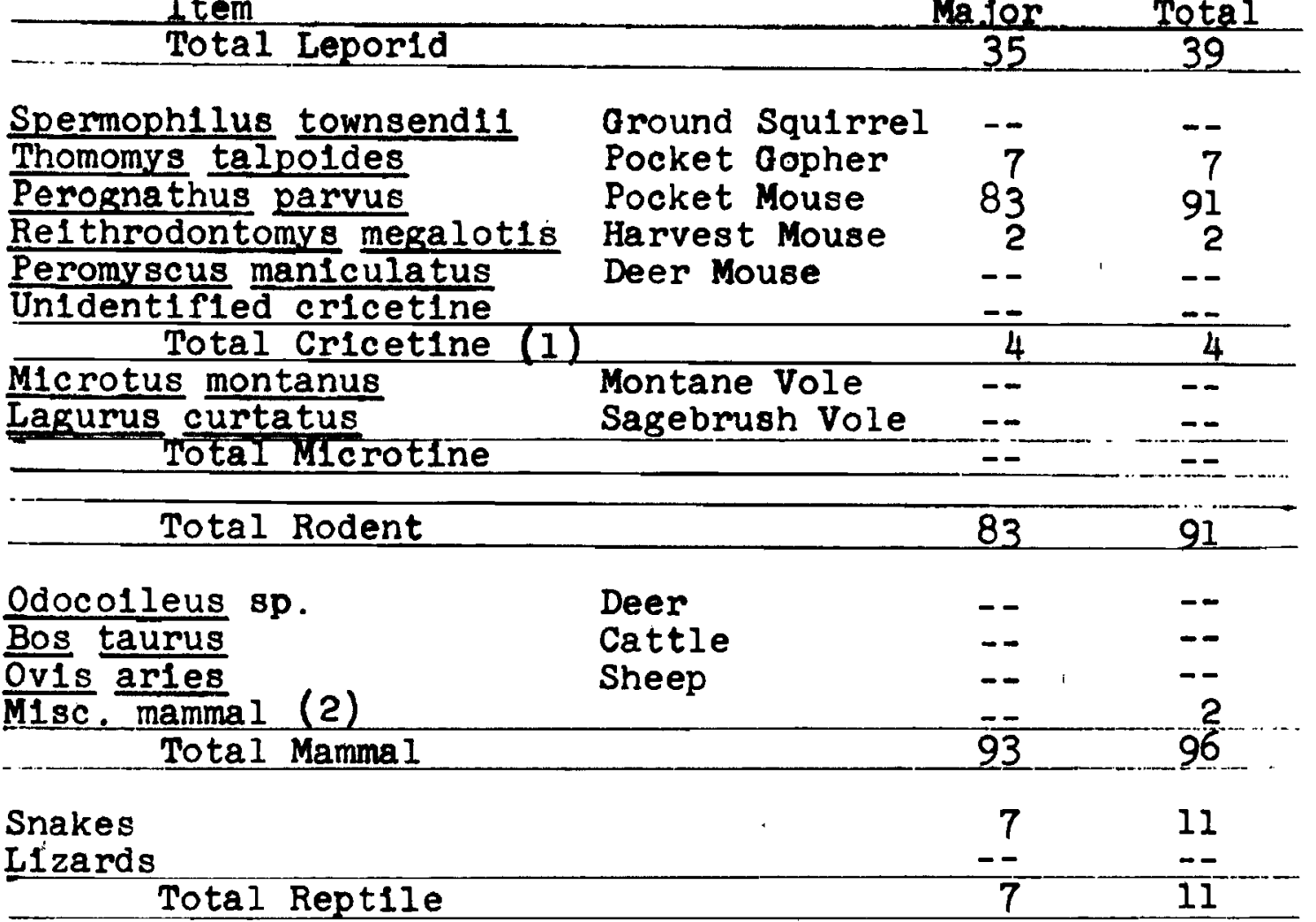

Unidentified Feathers

Passertform Feathers

Eggshell Total Aves (3)

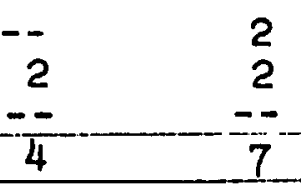

Tenebrionids

Orthoptera Total Insect

Darkling Beetles Grasshoppers 24 43

Apples

Other Fruit

arass Total Fruit

Misc. Matter (4)

(1) Includes one occurrence of Onychomys leucogaster

(2) Unidentifled large mammal

(3) Includes one occurrence of Buteo hawk (three claw na1ls)

(4) Plastlc wrapper 
COYOTE SCAT ANALYSIS- USERDA HANPORD RESERVATION

No. Analyzed Place Army Loop Road Collection Date 16 Sep 75 Ana 40 Occurrences Expressed as Percentages

\begin{tabular}{ccc} 
Item & Major & Total \\
\hline$\ldots . . . \quad$ Total Leporid & 10 & 12 \\
\hline
\end{tabular}

Spermoph1lus townsend11 Ground Squirrel Thomomys talpoides Perognathus parvus Re1throdontomys megalot1s Peromyscus maniculatus Unidentifled cricetine Total Cricetine M1crotus montanus Lagurus curtatus Total Microtine Pocket Oopher Pocket Mouse Harvest Mouse Deer Mouse Total Rodent e

Odoco1leus sp. Bos taurus Ovis aries Misc. mammal Total Mamma 1

\begin{tabular}{lr}
\hline 15 & $-\overline{1}$ \\
70 & 82 \\
-- & -- \\
-- & 2 \\
-- & -- \\
\hline-- & -- \\
\hline- & -- \\
\hline 85 & 85 \\
\hline- & -- \\
\hline- & -- \\
\hline- & -- \\
\hline 80 & 85 \\
\hline
\end{tabular}

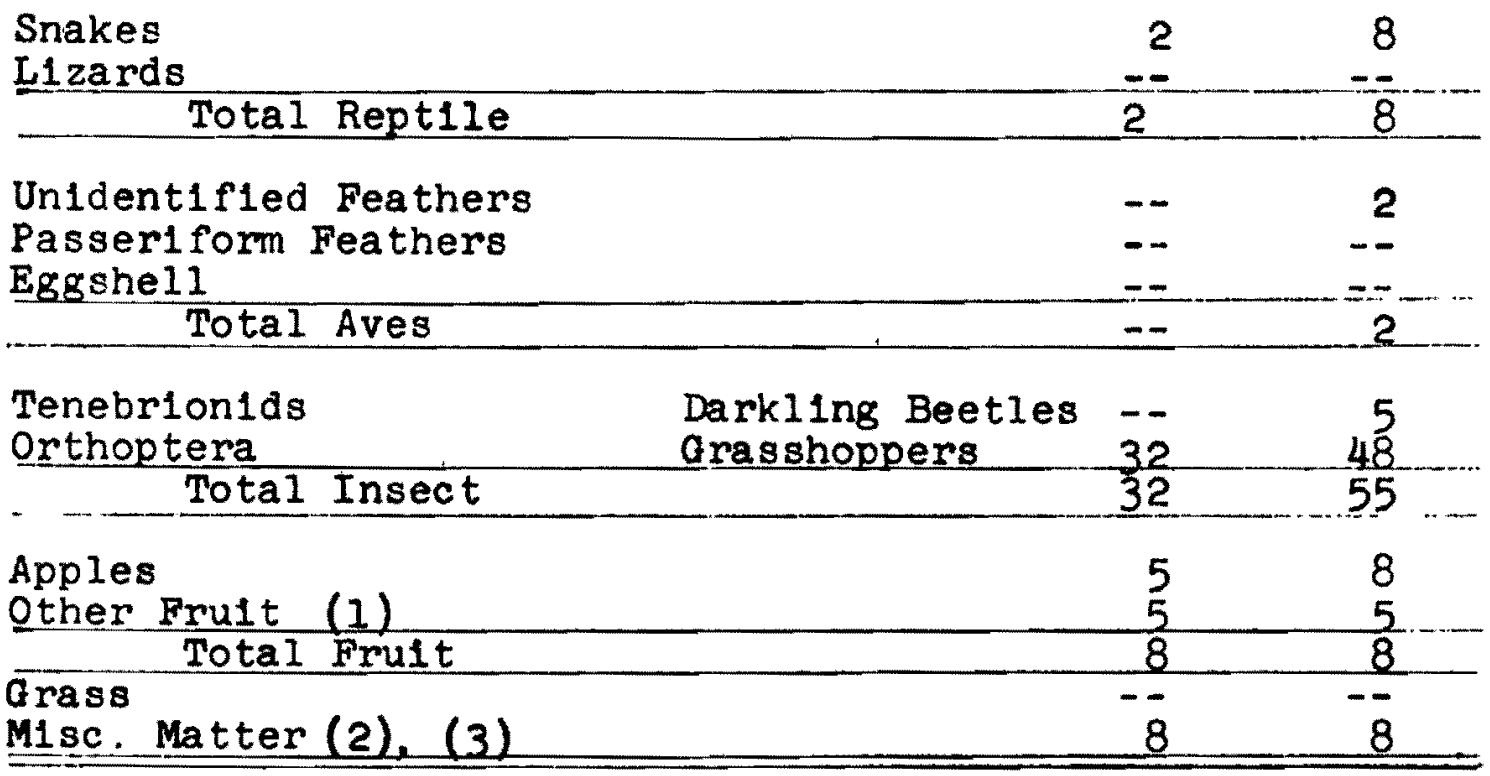

(1) Cantaloupe, two occurrences; grapes, one occurrence

(2) Aluminum and plastic food wrappers

(3) UnIdentifled material 
COYOTE SCAT ANALYSIS-USERDA HANFORD RESERVATION

No. Analyzed

Place Army Loop Road Collection Date 18 Oct $75 \quad 40$

Occurrences Expressed as Percentages Item

Total Leporid

Najor Total

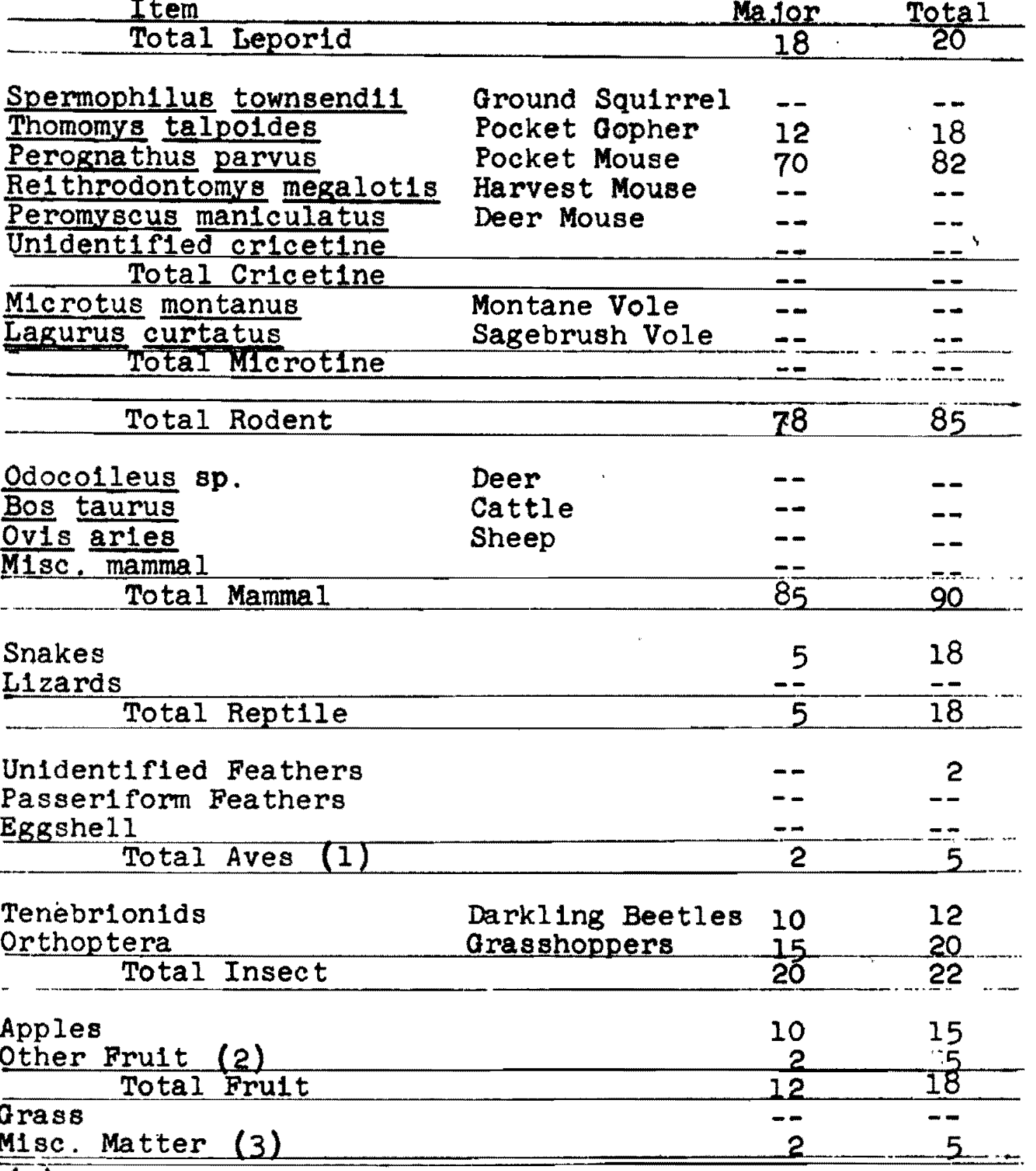

(1) Includes one occurrence of a gálinaceous blrd

(2) Cherries

(3) Bone from garabage dump, aluminum foll 
COYOTE SCAT ANALYSIS--USERDA HANPORD RESERVATION No. Analyzed

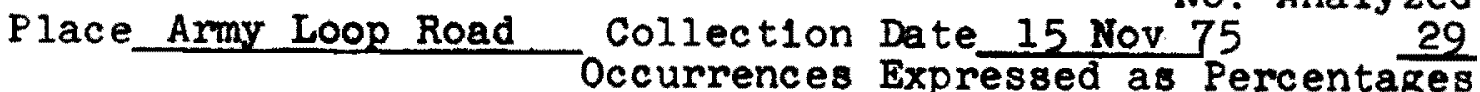
Item Total Leporid Mafor Total

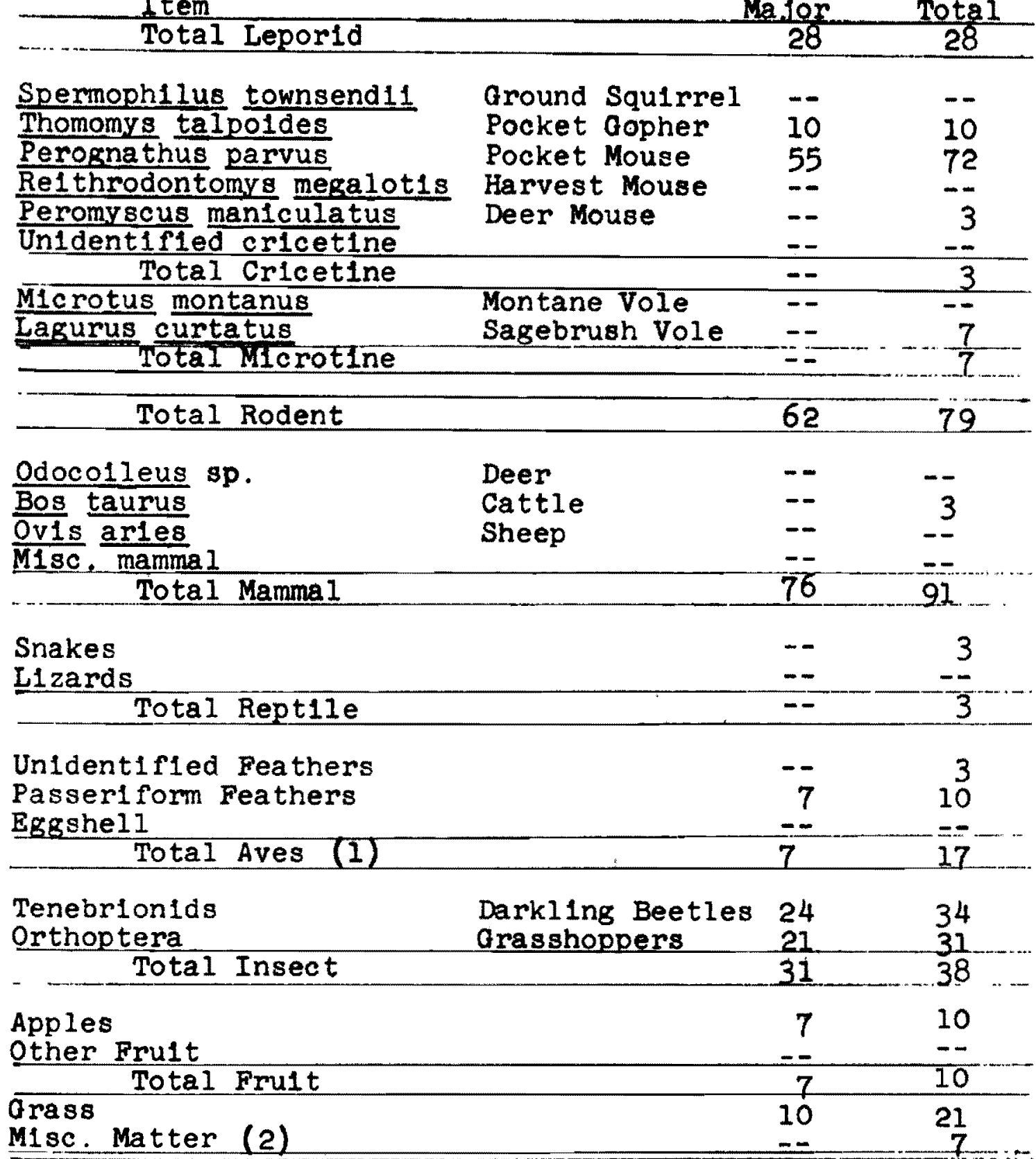

(1) Includes one occurrence of a gallinaceous bird

(2) Plastic food wrapper 
COYOTE SCAT ANALYSIS--USERDA HANFORD RESERVATION

Place Army Loop Road Collection Dite 23 Dec No. Analyzed

Occurrences Expressed as Percentages Item

Major

Total Leporid

73

Total

Spermoph1lus townsend11

Thomomys talpoldes

Perognathus parvus

Re1throdontomys megalotis

Peromyscus maniculatus

Unidentified cricetine Total Cricetine

Microtus montanus

Lasurus curtatus

lotal Microtine

Ground Squirrel

Pocket Gopher

Pocket Mouse

Harvest Mouse

Deer Mouse

73

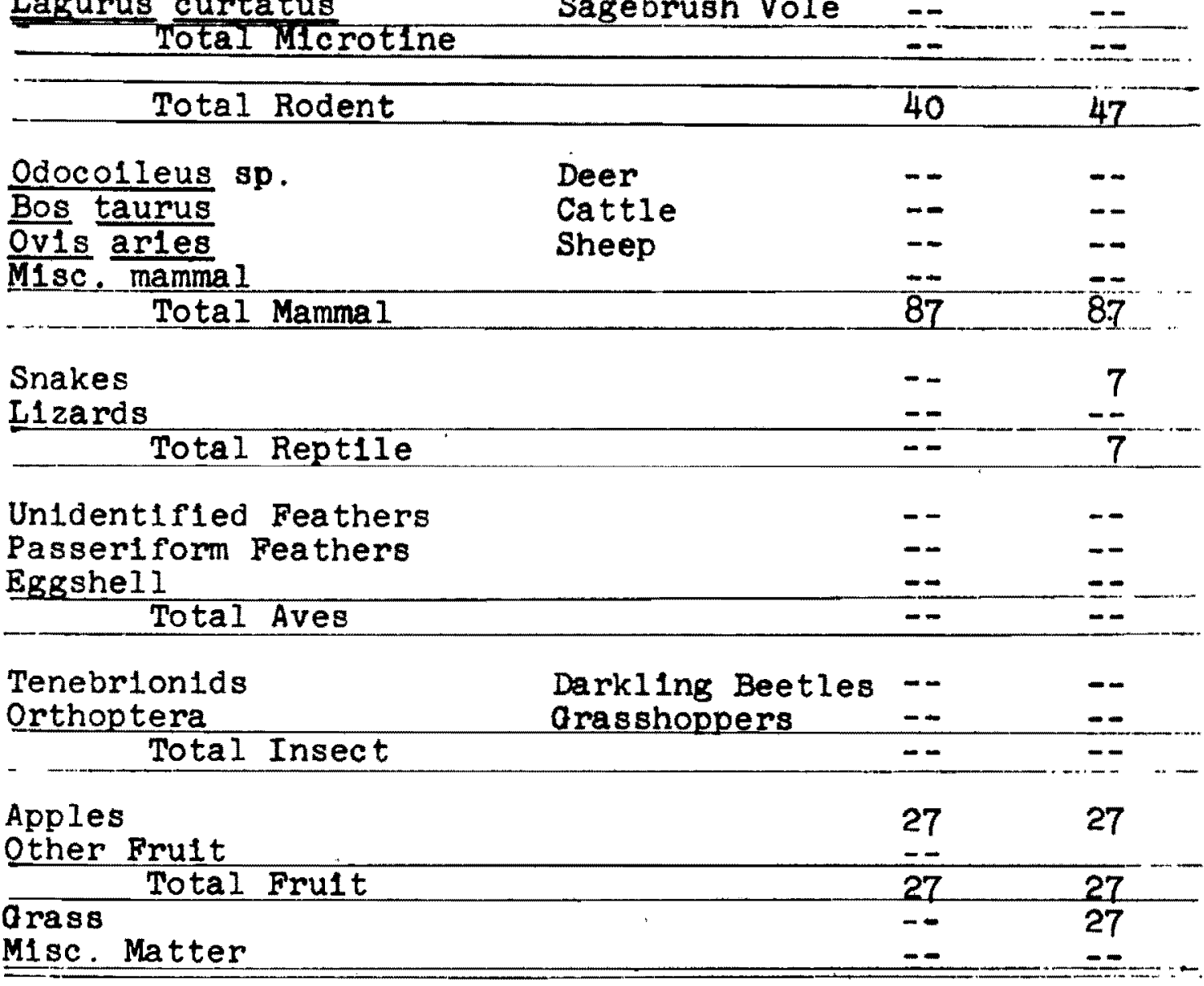


COYOTE SCAT ANALYSIS--USERDA HANPORD RESERVATION

Place No. Analyzed

Place Army Loop Road Collection Date $\frac{7 \text { Jan } 76}{\text { Occurrences Expressed as Percentages }}$ Item Tota1 Leporid

\begin{tabular}{|c|c|c|c|}
\hline 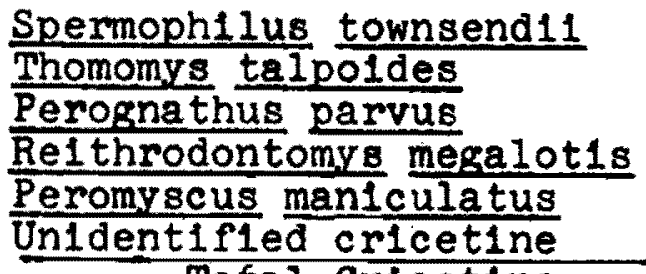 & $\begin{array}{l}\text { Ground Squirrel } \\
\text { Pocket Gopher } \\
\text { Pocket Mouse } \\
\text { Harvest Mouse } \\
\text { Deer Mouse }\end{array}$ & $\begin{array}{r}-- \\
19 \\
2 \\
5 \\
19 \\
\end{array}$ & $\begin{array}{r}-- \\
26 \\
5 \\
7 \\
29\end{array}$ \\
\hline $\begin{array}{l}\text { Total Cricetine } \\
\text { Microtus montanus } \\
\text { Lasurus } \frac{\text { curtatus }}{\text { Total Microtine }}\end{array}$ & $\begin{array}{l}\text { Montane Vole } \\
\text { Sagebrush Vole }\end{array}$ & $\begin{array}{r}26 \\
2 \\
-\frac{2}{7} \\
\end{array}$ & $\begin{array}{r}40 \\
2 \\
5 \\
10\end{array}$ \\
\hline Total Rodent & & 45 & 64 \\
\hline $\begin{array}{l}\frac{\text { Odocolleus }}{\text { Bos }} \\
\frac{\text { ovis }}{\text { Misc } \frac{\text { ardes }}{\text { mammal }}} \\
\text { Total Mammal }\end{array}$ & $\begin{array}{l}\text { Deer } \\
\text { Cattle } \\
\text { Sheep }\end{array}$ & $\begin{array}{r}-\overline{14} \\
-\frac{2}{90}\end{array}$ & $\begin{array}{l}17 \\
-\frac{-}{2} \\
93\end{array}$ \\
\hline $\begin{array}{l}\text { Snakes } \\
\text { Llzards } \\
\text { Total Rept1le }\end{array}$ & & $\begin{array}{l}2 \\
2 \\
5\end{array}$ & $\begin{array}{r}2 \\
5 \\
7\end{array}$ \\
\hline $\begin{array}{l}\text { Unidentifled Feathers } \\
\text { Passeriform Feathers } \\
\text { Eggshell } \\
\text { Total Aves }\end{array}$ & & $\frac{--}{--}$ & $-\frac{5}{-}$ \\
\hline $\begin{array}{l}\text { Tenebrionids } \\
\text { Orthoptera }\end{array}$ & $\begin{array}{l}\text { Darkling Beetles } \\
\text { Grasshoppers }\end{array}$ & - & $-\frac{-}{2}$ \\
\hline Total Insect & & -- & $\overline{2}$ \\
\hline $\begin{array}{l}\text { Apples } \\
\text { Other Fruit }\end{array}$ & & 38 & $\begin{array}{l}43 \\
-- \\
\end{array}$ \\
\hline $\begin{array}{l}\text { Total Fruit } \\
\text { Arass } \\
\text { M1sc. Matter } \text { (4) }\end{array}$ & & $\begin{array}{r}38 \\
12 \\
5\end{array}$ & $\frac{43}{29}$ \\
\hline
\end{tabular}

(1) Includes one occurrence of unidentifled microtine

2) Coyote underfur

3 Includes an occurrence of gallinaceous b1rd

(4) Bone ch1p from garbage; dirt; plast1c wrapper 
COYOTE SCAT ANALYSIS--USERDA HANFORD RESERVATION

Place No. Analyzed

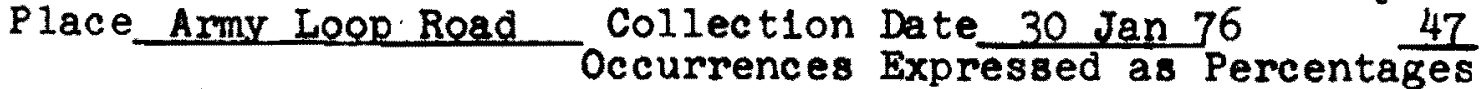
Item Total Lepor1d Major Total

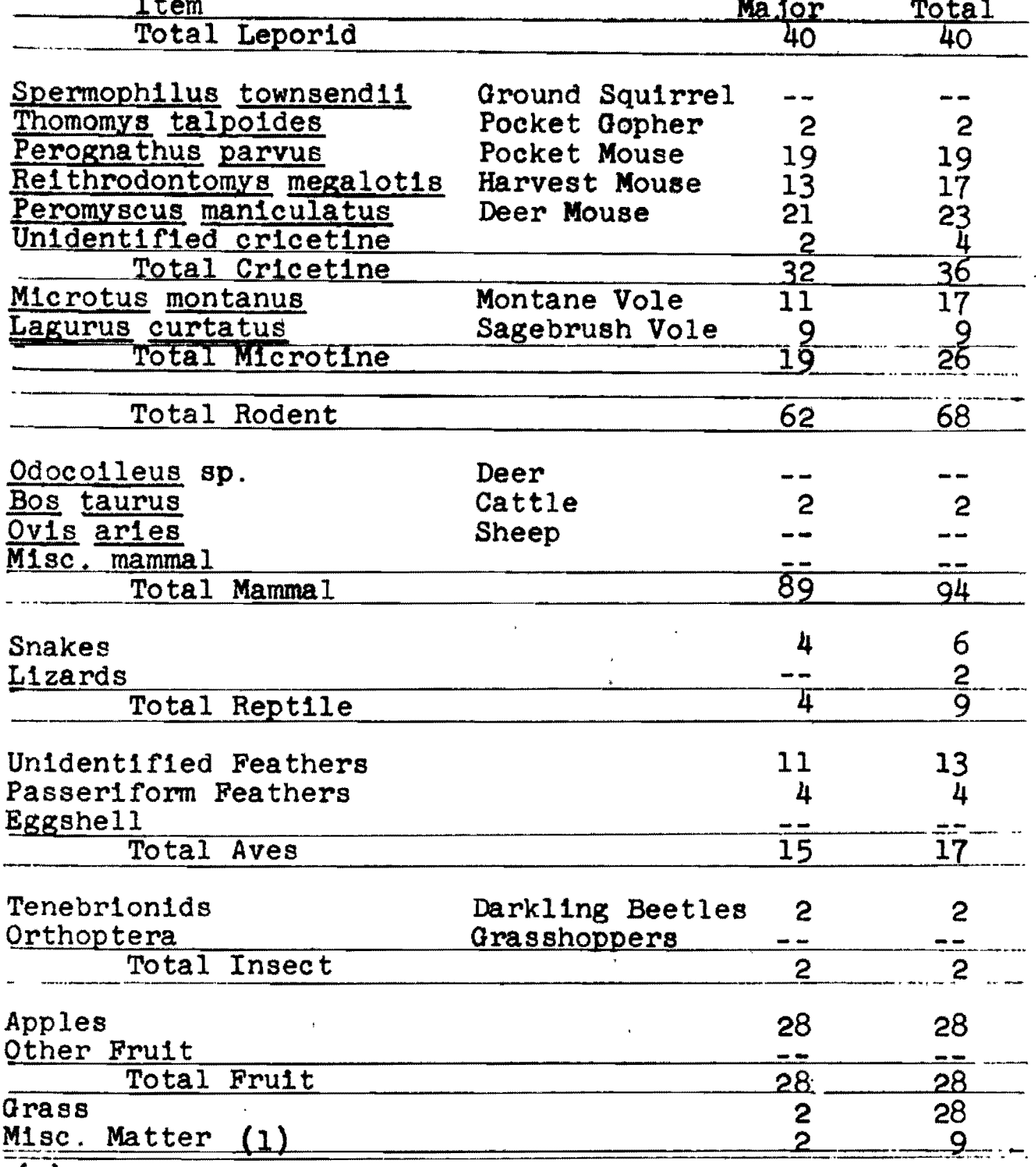

(I) Dirt 
APPENDIX B

COYOTE SCAT ANALYSIS

GATE 111 ROAD 
COYOTE SCAT ANALYSIS--USERDA HANPORD RESERVATION Place Gate 111 Road Collection Date 9 Ma 74 . Analyzed

Occurrences Expressed as Percentages Total Leporid Major 44 Total

\begin{tabular}{|c|c|c|c|}
\hline Total Leporid & & 44 & 44 \\
\hline 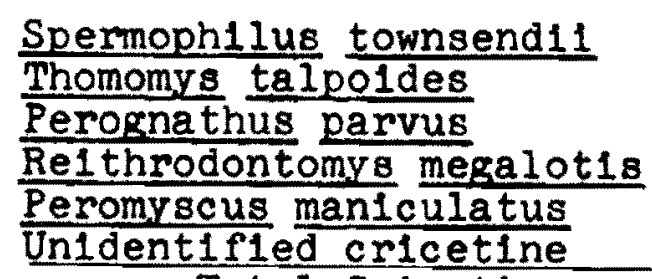 & $\begin{array}{l}\text { Ground Squirrel } \\
\text { Pocket Gopher } \\
\text { Pocket Mouse } \\
\text { Harvest Mouse } \\
\text { Deer Mouse }\end{array}$ & $\begin{array}{l}11 \\
-- \\
-- \\
-- \\
--\end{array}$ & $\begin{array}{l}11 \\
-- \\
-- \\
-- \\
--\end{array}$ \\
\hline $\begin{array}{l}\text { Total Cricetine } \\
\text { Microtus montanus } \\
\text { Lagurus curtatus }\end{array}$ & $\begin{array}{l}\text { Montane Vole } \\
\text { Sagebrush Vole }\end{array}$ & $\begin{array}{ll}-- \\
---\end{array}$ & $\begin{array}{l}-- \\
-- \\
--\end{array}$ \\
\hline Total Microtine & & $=$ & $=$ \\
\hline Total Rodent & & 11 & 11 \\
\hline $\begin{array}{ll}\frac{\text { Odocolleus }}{\text { Bos }} \text { sp. } & \text { (aurus } \\
\frac{\text { Ov1s }}{\text { M1sc. }} \frac{\text { aries }}{\text { mamma } 1} & \text { (2) } \\
\text { Total Mamma 1 }\end{array}$ & $\begin{array}{l}\text { Deer } \\
\text { Cattle } \\
\text { Sheep }\end{array}$ & $\begin{array}{l}-\overline{11} \\
\frac{-}{56} \\
100\end{array}$ & $\begin{array}{r}\overline{11} \\
\overline{56} \\
100\end{array}$ \\
\hline $\begin{array}{l}\text { Snakes } \\
\frac{\text { L1zards }}{\text { Total ReptIle }}\end{array}$ & & $=-$ & $\frac{11}{11}$ \\
\hline $\begin{array}{l}\text { Unident1 fled Feathers } \\
\text { Passer1 form Feathers } \\
\text { Eggshell } \\
\frac{\text { Total Aves }}{}\end{array}$ & & $\begin{array}{l}-- \\
-- \\
--\end{array}$ & $\begin{array}{l}11 \\
-- \\
11\end{array}$ \\
\hline $\begin{array}{l}\text { Tenebrionids } \\
\text { Orthoptera } \\
\text { Total Insect (3) }\end{array}$ & $\begin{array}{l}\text { Darkling Beetles } \\
\text { Grasshoppers }\end{array}$ & $\begin{array}{l}-- \\
-- \\
--\end{array}$ & $\frac{11}{22}$ \\
\hline $\begin{array}{l}\text { Apples } \\
\text { Other Fruit }\end{array}$ & & $\overline{-}$ & -- \\
\hline $\begin{array}{l}\text { Total Fruit } \\
\text { Mrass } \\
\text { Misc. Matter (4) }\end{array}$ & & $\overline{--}$ & $\begin{array}{l}-7 \\
44\end{array}$ \\
\hline
\end{tabular}

(1) One scat, collected April 9, 1974

(2) Horse (hair only)

(3) Includes a cicada occurrence

(4) Dirt 
COYOTE SCAT ANALYSIS--USERDA HANPORD RESERVATION

Place Gate 111 Road Collection Date 4 Nov 74 . Analyzed

Occurrences Expressed as Percentages

Item

Major

Total

Total Lepor1d

14

14

Spermoph1lus townsendi1 around Squirrel

Thomomys talpoldes

Perognathus parvus

Re1 throdontomys megalotis

Peromyscus maniculatus

Unident1ried cricetine

Total Cricetine

Microtus montanus

Lagurus curtatus

Total Microtine

Pocket Gopher

Pocket Mouge

Harvest Mouse

Deer Mouse

Total Rodent

Montane Vole

Sagebrush Vole

Total Rodent

Odocolleus sp.

Deer

Bos taurus

Cattle

Ov1s aries

M1sc. mammal

Sheep

Total Mammal

36

\begin{tabular}{ll}
-- & -- \\
-- & -- \\
36 & 50 \\
-- & -- \\
-- & -- \\
-- & -- \\
-- & -- \\
\hline- & -- \\
\hline- & $=-$ \\
\hline 36 & 50 \\
\hline
\end{tabular}

Snakes

L1zards

Total Rept1le

$\overline{7} \quad-\overline{7}$

$21 \quad 21$

64

71

Unidentified Feathers

Passeriform Fea thers

Eggshell

$$
\text { Total Aves }
$$

14

$1 \frac{-}{14}$

14

14

Tenebrionids

Orthoptera

Total Insect

Darkling Beetles

Grasshoppers

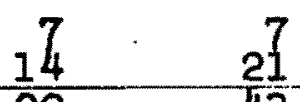

29

43

Apples

Other Fruit (1)

Total Fruit

arass

Misc. Matter (2)

$\overline{43}$

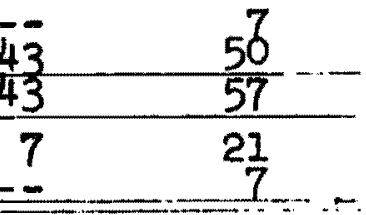

(1) Cherries, one apricot occurrence

(2) Plece of rubber 
COYOTE SCAT ANALYSIS--USERDA HANPORD RESERVATION

Place Gate 111 Road Collection Date Spring 1975(1) 25

Occurrences Expressed as Percentages Item

Total Leporid

Major

\begin{tabular}{ccc} 
Item & Major & Total \\
\hline Total Leporid & 24 & 24 \\
\hline
\end{tabular}

Spermoph11us townsend11

Thomomys talpoldes

Perognathus parvus

Re1throdontomy megalotis

Peromyscus maniculatus

Unidentified cricetine Total Cricetine

Microtus montanus

Lagurus curtatus

Ground Squirrel

Pocket Gopher

Pocket Mouse

Harvest Mouse

Deer Mouse 4

$8 \quad 12$

$12 \quad 16$

$48 \quad 56$

lotal Merotine

Montane Vole

4

Sagebrush Vole

$--$

$-$

Total Rodent

28

$--$

$-$

40

40

\begin{tabular}{|c|c|c|c|}
\hline Total Rodent & & 56 & 76 \\
\hline $\begin{array}{l}\frac{\text { Odocolleus }}{\text { Bos }} \mathbf{\text { taurus }} \\
\frac{\text { Ov1s }}{\text { M1sc, } \frac{\text { arles }}{\text { mamma } 1}} \\
\text { Total Mammal }\end{array}$ & $\begin{array}{l}\text { Deer } \\
\text { Cattle } \\
\text { Sheep }\end{array}$ & $\begin{array}{r}-- \\
-- \\
-- \\
80\end{array}$ & $\begin{array}{r}-- \\
-- \\
--\end{array}$ \\
\hline $\begin{array}{l}\text { Snakes } \\
\text { I1zards }\end{array}$ & & - & - \\
\hline Total Rept1le & & $-\infty$ & - \\
\hline $\begin{array}{l}\text { Unident1 fled Feathers } \\
\text { Passert form Feathers } \\
\text { Eggshell } \\
\text { Total Aves }\end{array}$ & . & $\begin{array}{r}4 \\
-- \\
--\end{array}$ & $\begin{array}{l}16 \\
-- \\
-5\end{array}$ \\
\hline $\begin{array}{l}\text { Tenebrionids } \\
\text { Orthoptera }\end{array}$ & $\begin{array}{l}\text { Darkl1ng Beetles } \\
\text { Grasshoppers }\end{array}$ & $\begin{array}{r}4 \\
--\end{array}$ & $\begin{array}{r}4 \\
-=\end{array}$ \\
\hline Total Insect & & 4 & 4 \\
\hline $\begin{array}{l}\text { Apples } \\
\text { Other Fruit (2) }\end{array}$ & & 8 & 8 \\
\hline Total Fruit & & 12 & 16 \\
\hline $\begin{array}{l}\text { Grass } \\
\text { Misc. Matter (3) }\end{array}$ & & $\begin{array}{l}4 \\
4 \\
\end{array}$ & $\begin{array}{r}24 \\
4\end{array}$ \\
\hline
\end{tabular}

(1) Collection dates-March 16 and Apri1 6, 1975

(2) Cherries, grapes

(3) Canvas cloth 
COYOTE SCAT ANALYSIS--USERDA HANFORD RESERVATION

Place No. Analyzed

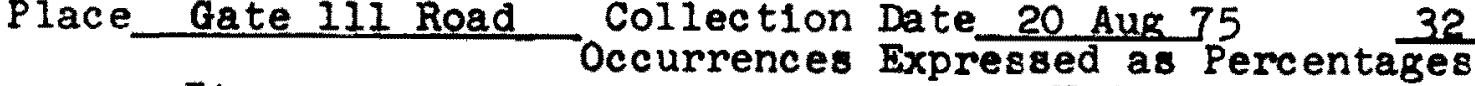
Item Total Lepor1d Major 6 Total

\begin{tabular}{ccc}
\hline Total Leporld & 6 & 9 \\
\hline
\end{tabular}

Spermoph1lus townsend11 Thomomys talpoldes Perognathus parvus Re1throdontomys megalotis Peromyscus maniculatus $\frac{\text { Unident1fied cricetine }}{\text { Total Cricetine }}$ Microtus montanus Lagurus curtatus Total Microtine $\frac{\text { Unident1fied cricetine }}{\text { Total Cricetine }}$

\section{Ground Squirrel Pocket Gopher Pocket Mouse Harvest Mouse Deer Mouse} Total Rodent

Odocolleus sp.

Bos taurus

Ovis aries

M1sc. mamma Total Mammal

Montane Vole Sagebrush Vole

3
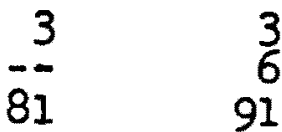

$81 \quad 91$
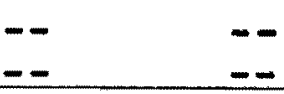

$-\frac{3}{3}$

3 3

$\begin{array}{lll}94 & 94\end{array}$

Deer

Cattle

Sheep

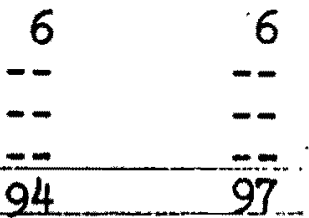

6 $91 \quad 97$

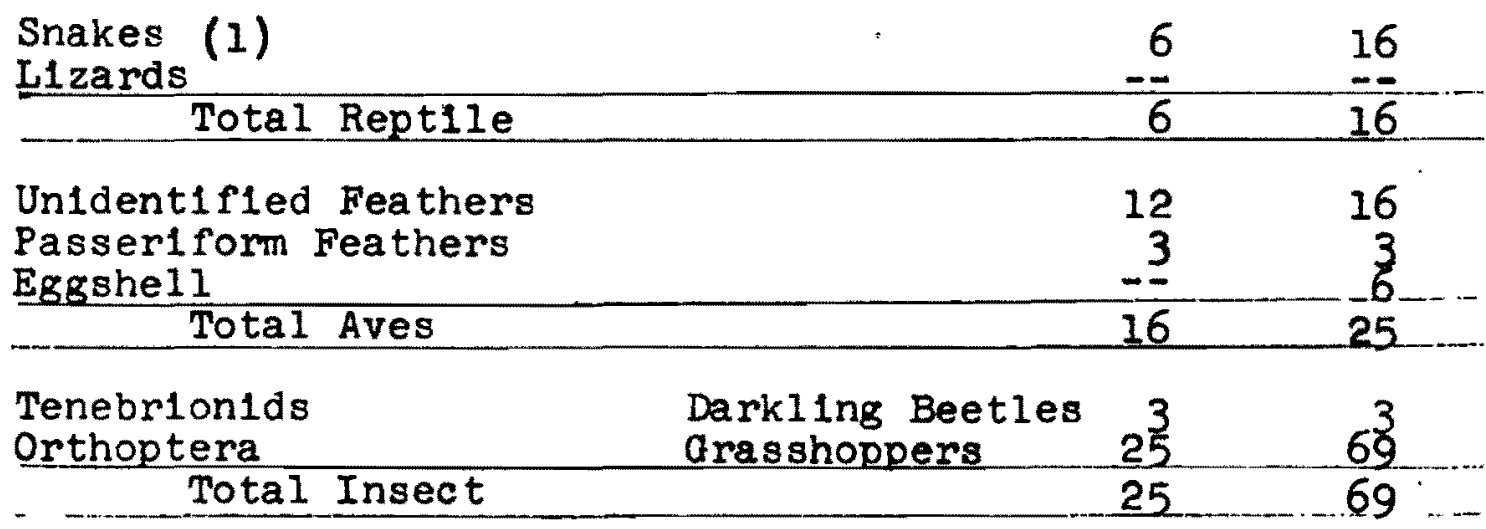

Apples

other Fruit (2) Trass Total Fruit

Misc. Matter 
COYOTE SCAT ANALYSIS--USERDA HANFORD RESERVATION

Place Gate 111 Road No. Analyzed Occurrences Expressed as Percentages Item Total Lepor1d Major

\begin{tabular}{ccc} 
Item & Major & Total \\
\hline Total Lepor1d & 3 & 3
\end{tabular}

Spermoph1lus townsend11 Thomomys talpoldes Perognathus parvus Re1throdontomys megalot1s Peromyscus maniculatus Un1dentified cricetine Microtus montanus Total Cricetine Lagurus curtatus Total Microtine

Ground Squirrel Pocket aopher Pocket Mouse Harvest Mouse Deer Mouse Total Rodent

Odocolleus sp.

Bos taurus

Ovis aries

M1sc. mamma 1 Total Mamma I

Montane Vole

Sagebrush Vole

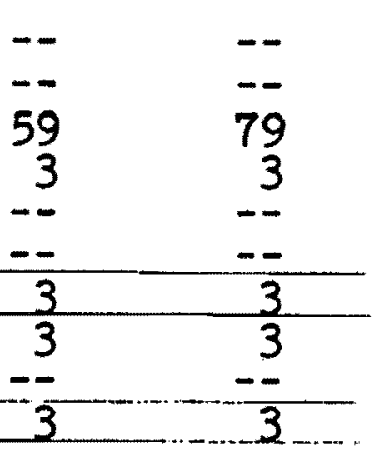

62 75

Deer

Cattle

Sheep

$\begin{array}{rr}-- & - \\ -3 & 3 \\ 62 & 75\end{array}$

Snakes

Lizards Total Rept1le

$\begin{array}{cc}3 & 9 \\ -3 & 9\end{array}$

Unidentifled Feathers Passertform Fea thers Eggshell Total Aves

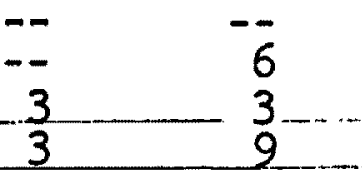

Tenebrionids

Orthoptera Total Insect Darkling Beetles Grasshoppers

47 12 47

Apples

Other Frult (1) Total Frult

Grass

Misc. Matter

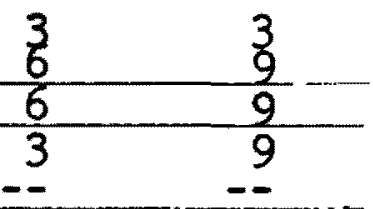


APPENDIX C

\title{
COYOTE SCAT ANALYSIS
}

\author{
SNIVELY ROAD
}


COYOTE SCAT ANALYSIS--USERDA HANPORD RESERVATION

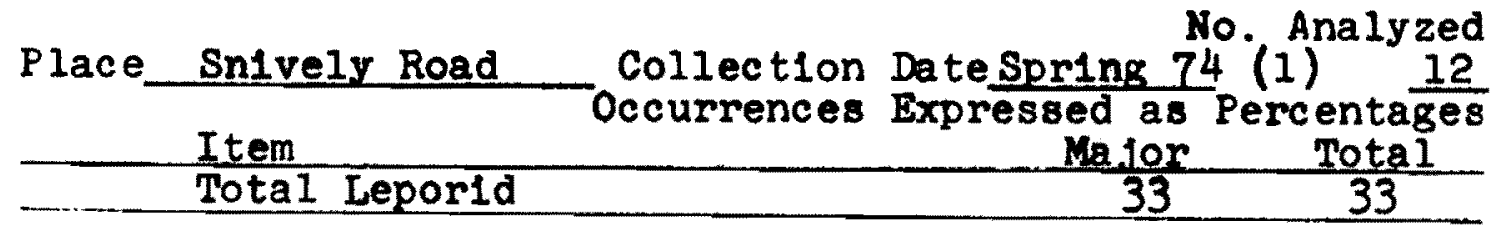

Spermoph1lus townsend11

Thomomys talpoides

Perognathus parvus

Re1throdontomys megalotis

Peromyscus maniculatus

Unidentified cricetine

Microtus montanus

Total Cricetine

Lagurus curtatus

Total Microtine
Ground Squirrel

Pocket Gopher

Pocket Mouse

Harvest Mouse

Deer Mouse

Montane Vole

Sagebrush Vole

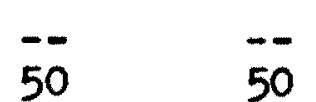

$33 \quad 33$

$-\overline{8} \quad--$

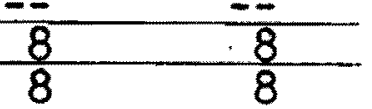

58

58

92

92
Odocolleus sp.

Bos taurus

Ovis aries

M1sc, mammal

Total Mamma 1

Deer

Cattle

Sheep

\begin{tabular}{ll}
8 & 8 \\
-- & -- \\
-- & -- \\
\hline 00 & 100
\end{tabular}

Snakes

Lizards Total Reptile

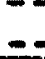

$-\infty$

Unldentifled Feathers

Passert form Feathers

Eggshell

Total Aves

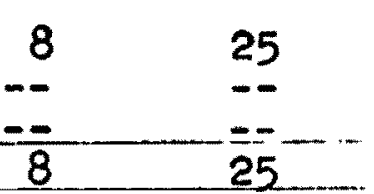

Tenebrionids

Orthoptera Total Insect

Darkling Beetles Qrasshoppers
$--$

$-$

$--$

Apples

other Fruit

\begin{tabular}{lcc} 
Total Fruit & -- & $-\overline{-}$ \\
\hline Mrass & -- & 17 \\
Misc. Matter & -- & --
\end{tabular}

(1) Collection dates-Mar. 27, 1974 (5 scats), May 16, 1974 (7 scats).

(2) Includes one occurrence of house mouse (Mus musculus) 
COYOTE SCAT ANALYSIS--USERDA HANPORD RESERVATION

Place Snively Road Collection Dat Analyzed

Occurrences Expressed as Percentages Item Total Leporid Major

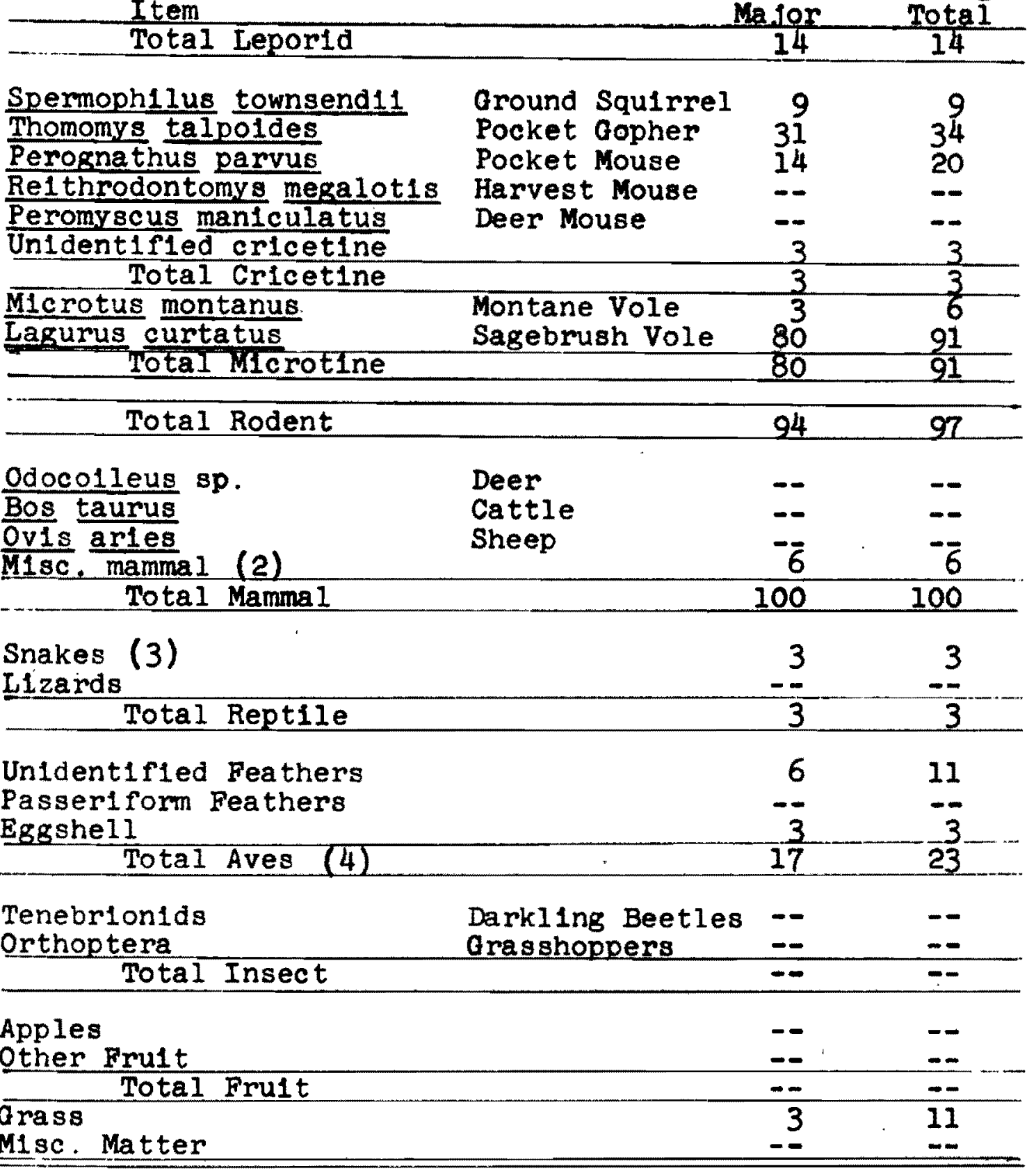

(1) Collection dates--Mar. 15 (10 scats) April 5 (15 scats), May 3 (10 scats).

(2) Marmot; coyote (toenall only)

(3) Gopher snake (P1tuoph1s melanoleucus)

(4) Includes three occurrences of gallinaceous bird 
COYOTE SCAT ANALYSIS--USERDA HANFORD RESERVATION

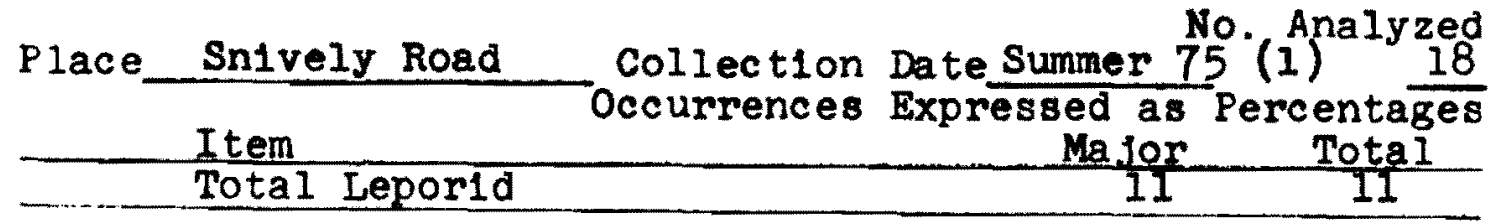

\begin{tabular}{|c|c|c|c|}
\hline 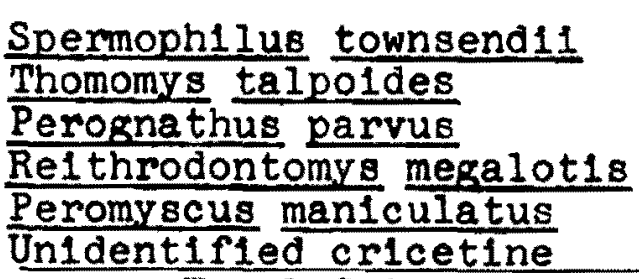 & $\begin{array}{l}\text { Ground Squirrel } \\
\text { Pocket Gopher } \\
\text { Pocket Mouse } \\
\text { Harvest Mouse } \\
\text { Deer Mouse }\end{array}$ & $\begin{array}{l}-- \\
17 \\
33 \\
-- \\
-- \\
--\end{array}$ & $\begin{array}{l}-- \\
22 \\
33 \\
-- \\
-- \\
--\end{array}$ \\
\hline $\begin{array}{l}\text { Total Cricetine } \\
\text { Microtus montanus } \\
\text { Lagurus curtatus } \\
\text { Total Microtine }\end{array}$ & $\begin{array}{l}\text { Montane Vole } \\
\text { Sagebrush Vole }\end{array}$ & $\begin{array}{l}-- \\
33 \\
67 \\
78\end{array}$ & $\begin{array}{l}-- \\
33 \\
67 \\
78\end{array}$ \\
\hline Total Rodent & & 89 & 89 \\
\hline 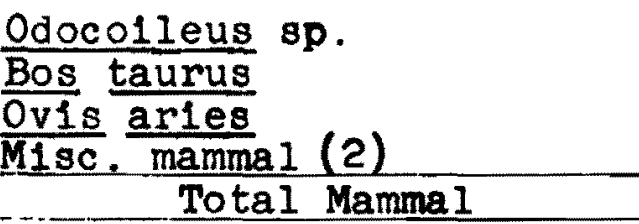 & $\begin{array}{l}\text { Deer } \\
\text { Cattle } \\
\text { Sheep }\end{array}$ & $\begin{array}{r}-- \\
-\overline{6} \\
89\end{array}$ & $\frac{-}{--}$ \\
\hline $\begin{array}{l}\text { Snakes } \\
\text { Llzards } \\
\text { Total Reptile }\end{array}$ & & $\overline{--}$ & $\begin{array}{l}-- \\
--\end{array}$ \\
\hline $\begin{array}{l}\text { Unidentifled Feathers } \\
\text { Passeriform Feathers } \\
\text { Eggshell } \\
\frac{\text { Total Aves (3) }}{2}\end{array}$ & & $\frac{6}{11}$ & $\frac{6}{11}$ \\
\hline $\begin{array}{l}\text { Tenebrionids } \\
\text { Orthoptera } \\
\text { Total Insect } \\
\end{array}$ & $\begin{array}{l}\text { Darkling Beetles } \\
\text { Grasshoppers }\end{array}$ & $\frac{17}{17}$ & $\overline{17}$ \\
\hline $\begin{array}{l}\text { Apples } \\
\text { Other Fruit (4) } \\
\text { Total Fruit }\end{array}$ & & $\frac{-\overline{6}}{6}$ & $\frac{-7}{6}$ \\
\hline $\begin{array}{l}\text { Mrass } \\
\text { Misc. Matter }\end{array}$ & & 6 & 22 \\
\hline
\end{tabular}

\footnotetext{
(1) Collection dates--Jun. 25 (6 scats), Jul. 23 (6 scats), Aug. 20 ( 6 scats).

(2) Neotome cinereus

(3) Includes one occurrence of gallinaceous bird

(4) Unidentified berries
} 
COYOTE SCAT ANALYSIS--USERDA HANFORD RESERVATION

\begin{tabular}{|c|c|c|c|c|}
\hline Iace & Snlvely Road & Collection & Date Fall 75 & N(i) ${ }^{\text {Analyzed }}$ \\
\hline & Item & Occurrences & $\begin{array}{r}\text { Expressed as } \\
\text { Ma.jor }\end{array}$ & $\begin{array}{c}\text { Percentages } \\
\text { Total }\end{array}$ \\
\hline & Total Lepor1d & & -0 & -- \\
\hline
\end{tabular}

Spermoph1lus townsend11 Ground Squirrel

Thomomys talpoldes

Perognathus parvus

Pocket Gopher

Pocket Mouse

Re1throdontomys megalotis

Peromyscus maniculatus

Unidentifled cricetine

Total Cricetine

Microtus montanus

Lagurus curtatus

Harvest Mouse

Deer Mouse

lotal Microtine

Montane Vole

Sagebrush Vole

\begin{tabular}{cc}
-- & -- \\
37 & 37 \\
11 & 19 \\
-- & 4 \\
-- & $-\overline{4}$ \\
-- & 7 \\
\hline 33 & 37 \\
63 & $\frac{63}{78}$ \\
\hline 78
\end{tabular}

Total Rodent

93

93

Odocolleus sp.

Bos taurus

Ov1s aries

M1sc. mammal

Deer

Cattle

Sheep

$\begin{array}{ll}4 & 7 \\ -- & --\end{array}$

Total Mammal

100

100

Snakes

Lizards

Total Reptile

-- $\quad--$

$--$

$--$

Unidentified Feathers

Passeriform Feathers

Eggshell

Total Aves

(2)

$\begin{array}{ll}- & 4\end{array}$

$--\frac{-}{4}$

$7 \quad 15$

Tenebrionids

Orthoptera

Total Insect

Darkling Beetles

Grasshoppers

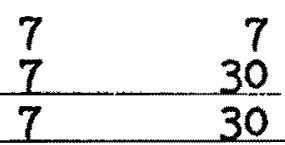

Apples

Other Fruit

arass

Misc. Matter Total Fruit

$-$

$-$

$--$

$-$

(1) Collection dates--Sept. 21 (8 scats), oct. 19 (14 scats), Nov. 15 ( 5 scats).

(2) Includes two occurrences of gallinaceous bird 
COYOTE SCAT ANALYSIS--USERDA HANPORD RESERVATION

\begin{tabular}{|c|c|c|c|}
\hline \multirow[t]{2}{*}{ Place } & Snively Road & \multirow{2}{*}{\multicolumn{2}{|c|}{$\begin{array}{r}\text { Collection Date } \frac{30 \text { Jan } 76}{\text { No. Analyzed }} \\
\text { Occurrences } \\
\text { Expressed as } \\
\text { Major } \\
\text { Percentages } \\
\text { Total }\end{array}$}} \\
\hline & & & \\
\hline & Total Leporid & 6 & 6 \\
\hline
\end{tabular}

Spermoph1lus townsend11 Thomomys talpoides Perognathus parvus Re1throdontomys megalot1s Peromyscus man1culatus Un1dentifled cricetine Microtus montanus Lagurus curtatus Total Microtine Total Rodent Ground Squirrel Pocket Gopher Pocket Mouse Harvest Mouse Deer Mouse $\frac{\text { Total }}{\text { Total }}$

Bos taurus

Ov1s aries

M1sc. mamma Total Mammal tine

Snakes

Lizards Total Rept1le

Deer

Cattle Montane Vole Sagebrush Vole Sheep

97 97

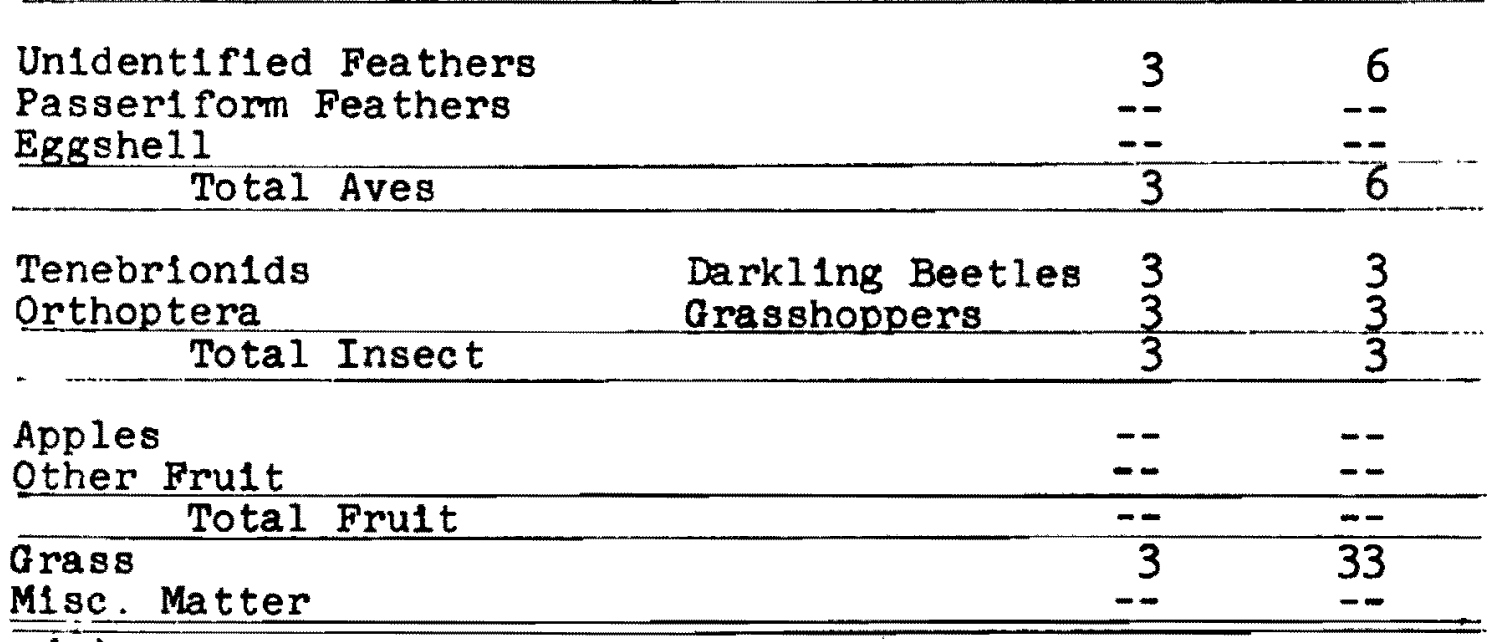

(1) Untdent1fled large mammail 
APPENDIX D

COYOTE SCAT ANALYSIS

1200 FOOT ROAD 
COYOTE SCAT ANALYSIS--USERDA HANPORD RESERVATION Place 1200 Foot Road Collection Date_Spring 1974(1) 23 Occurrences Expressed as Percentages Item Total Leporid Najor Total

\begin{tabular}{ccc} 
Item & Najor & Total \\
\hline Total Leporid & 43 & 48
\end{tabular}

Spermoph1lus townsend11 Thomomys talpo1des Perognathus parvus Re1throdontomys megalotis Peromyscus maniculatus Unidentified cricetine Microtus montanus Total Cricetine Lagurus curtatus Total Microtine Ground Squirrel Pocket Qopher Pocket Mouse Harvest Mouse Deer Mouse Total Rodent

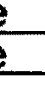

Montane Vole Sagebrush Vole

\begin{tabular}{|c|c|c|c|}
\hline Total Rodent & & 65 & 70 \\
\hline $\begin{array}{l}\frac{\text { Odocolleus }}{\text { Bos }} \text { sp. } \\
\frac{\text { taurus }}{\text { Ov1s }} \\
\frac{\text { Misc }}{\text { mammal }}\end{array}$ & $\begin{array}{l}\text { Deer } \\
\text { Cattle } \\
\text { Sheep }\end{array}$ & $\begin{array}{l}-- \\
-- \\
--\end{array}$ & $=$ \\
\hline Total Mammal & & 91 & 96 \\
\hline $\begin{array}{l}\text { Snakes } \\
\text { L1zards }\end{array}$ & & -- & $\overline{--}$ \\
\hline Total Reptile & & $=$ & $=$ \\
\hline
\end{tabular}

Unidentified Feathers Passeriform Fea thers

Eggshell Total Aves

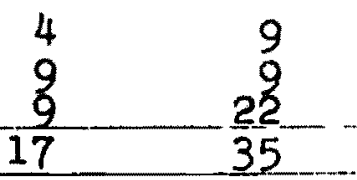

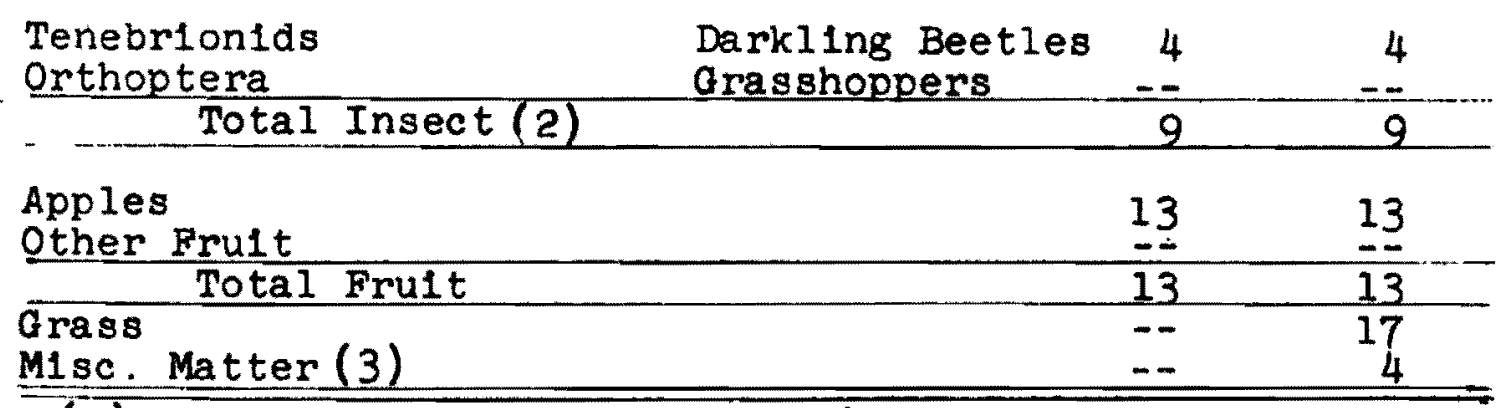

(1) March 3, 22, 27, 30; Apr11 6, 7, 11; May 11, 12, 14, 22 were the collection dates.

(2) Includes one occurrence of an unidentifled insect

(3) Dirt 
COYOTE SCAT ANALYSIS--USERDA HANPORD RESERVATION

Place 1200 Foot Road Collection Datesummer 1974 Analyzed Occurrences Expressed as Percentages Item Total Leporid Major Total

\begin{tabular}{crc} 
Item & Major & Total \\
\hline Total Leporid & 18 & 18 \\
\hline
\end{tabular}

Spermoph11us townsend11 Thomomys talpoldes Perognathus parvus Re1throdontomys megalotis Peromyscus maniculatus Un1dent1fied cricetine Microtus montanus Total Cricetine Lagurus curtatus Total Microtine Ground Squirrel $6 \quad 6$ Pocket Qopher Pocket Mouse Harvest Mouse Deer Mouse Total Rodent

(na

Montane Vole Sagebrush Vole

\begin{tabular}{|c|c|c|c|}
\hline Total Microtine & & -- & $=$ \\
\hline Total Rodent & & 29 & 29 \\
\hline $\begin{array}{l}\frac{\text { Odocolleus }}{\text { Bos }} \text { sp. } \\
\frac{\text { taurus }}{\text { Ov1s }} \\
\text { M1sc. } \frac{\text { aries }}{\text { mammal }}\end{array}$ & $\begin{array}{l}\text { Deer } \\
\text { Cattle } \\
\text { Sheep }\end{array}$ & $\overline{18}$ & $\begin{array}{r}-\overline{6} \\
18\end{array}$ \\
\hline Total Mammal & & 29 & 35 \\
\hline $\begin{array}{l}\text { Snakes } \\
\text { Lizards }\end{array}$ & & -- & -- \\
\hline Total Rept1le & & -- & -- \\
\hline $\begin{array}{l}\text { Unidentifled Feathers } \\
\text { Passeriform Feathers } \\
\text { Eggshell }\end{array}$ & & $-\frac{13}{6}$ & $-\frac{29}{6}$ \\
\hline Total Aves & & 18 & 35 \\
\hline
\end{tabular}

\begin{tabular}{|c|c|c|}
\hline $\begin{array}{l}\text { Tenebrionids } \\
\text { Orthoptera }\end{array}$ & $\begin{array}{lr}\text { Darkling Beetles } & 6 \\
\text { Grasshoppers } & 35 \\
\end{array}$ & 47 \\
\hline Total Insect & en & 47 \\
\hline $\begin{array}{l}\text { Apples } \\
\frac{\text { Other Fruit (2) }}{\text { Total Fruit }}\end{array}$ & $\frac{\overline{35}}{35}$ & $\frac{\overline{4}}{47}$ \\
\hline $\begin{array}{l}\text { Miscs. Matter (4) } \\
\text { Misc. }\end{array}$ & $=$ & 29 \\
\hline
\end{tabular}

(1) Collection dates--June 20, 22; July 12, 24; Aug. 2

2) Cherries, $81 x$ occurrences

3. Unident1fied berries, one occurrence 
COYOTE SCAT ANALYSIS--USERDA HANFORD RESERVATION

Collection Date 5-12 Nov 74 tem Total Lepor1d Occurrences Expressed as Percentages

\begin{tabular}{|c|c|c|c|}
\hline $\begin{array}{l}\text { Item } \\
\text { Total Leporid }\end{array}$ & & $\frac{10 x}{5}$ & $\frac{\text { Total }}{5}$ \\
\hline Spermophllus townser & Ground Sautrrel & $=$ & -- \\
\hline Thomomys talpoldes & Pocket Gopher & 9 & 9 \\
\hline Perognathus parvus & Pocket Mouse & 50 & 59 \\
\hline Re1throdontomys megalotis & Harvest Mouse & $=-$ & -2 \\
\hline Peromyscus maniculatus & Deer Mouse & - & \\
\hline Unldentifled cricetine & & & 5 \\
\hline Total Cricetine & & 5 & 5 \\
\hline M1crotus montanus & Montane Vole & -- & -2 \\
\hline agurus curtatus & Sagebrush Vole & 5 & 5 \\
\hline Total Microtine & & 5 & 5 \\
\hline Total Rodent & & 59 & 68 \\
\hline
\end{tabular}

Odocolleus sp. Deer Bos taurus Ov1s aries M1sc. mammal Cattle Sheep

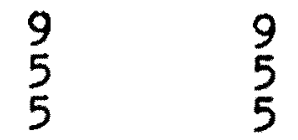
Total Mammal 64

Snakes

Lizards Total Rept1le

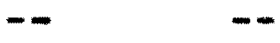

$-$ $-$

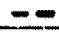

Unidentified Feathers Passer1form Feathers Egsshel1 Total Aves

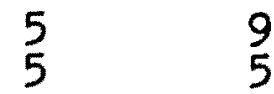

$-$

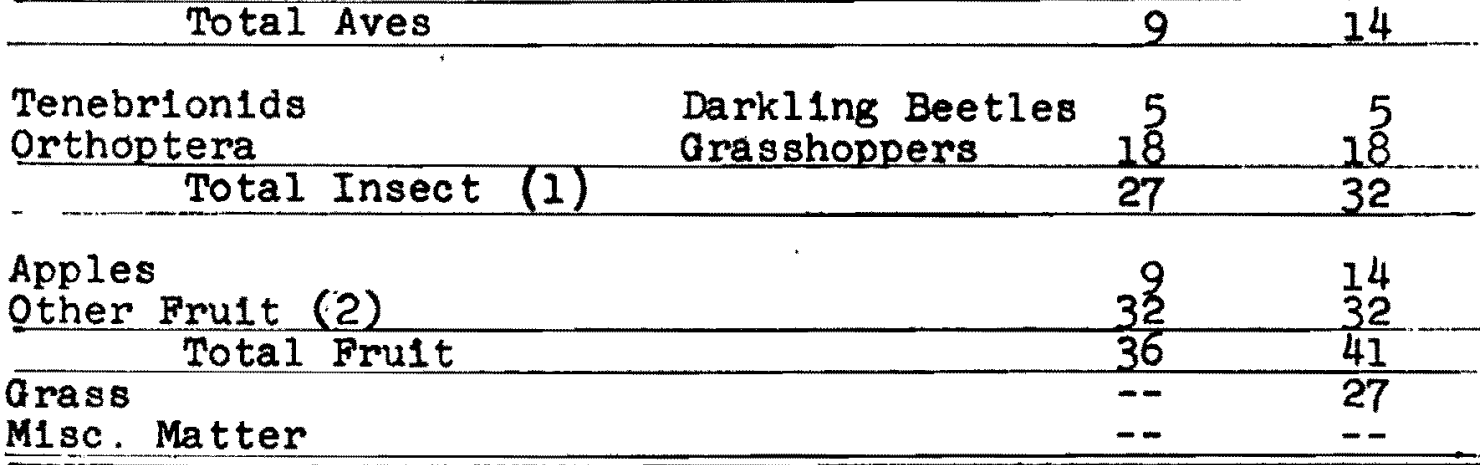

(1) Includes two occurrences of unidentifled insects

(2) Cherries 
COYOTE SCAT ANALYSIS--USERDA HANFORD RESERVATION

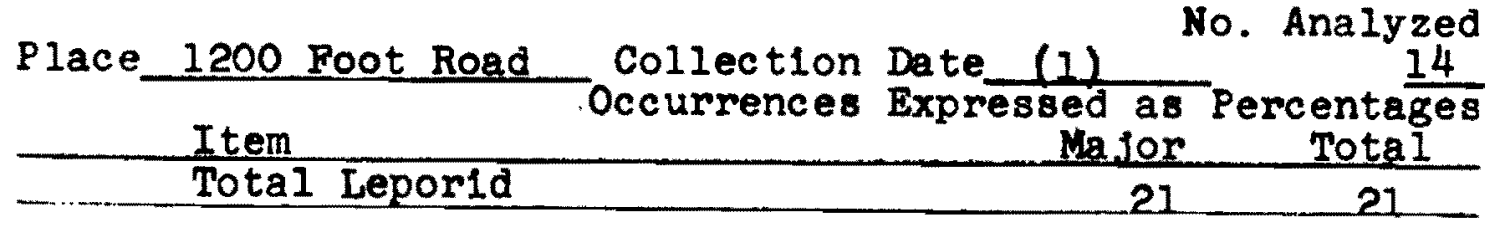

Spermoph1lus townsend11 Ground Squirrel

Thomomys talpoldes

Perognathus parvus

Re1 throdontomyg mege

Peromyscus maniculatus

Unidentifled cricetine Total Cricetine

Microtus montanus

(2) Pocket Gopher

Harvest Mouse

Deer Mouse

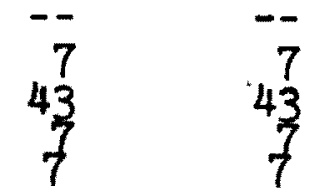

Lagurus curtatus

Total Microtine

14

$14 \quad 14$

(3)

Total Rodent

Montane Vole

21

Sagebrush Vole

$\overline{14} \quad \overline{14}$

$\frac{14}{14}-\cdots-\frac{14}{14}$

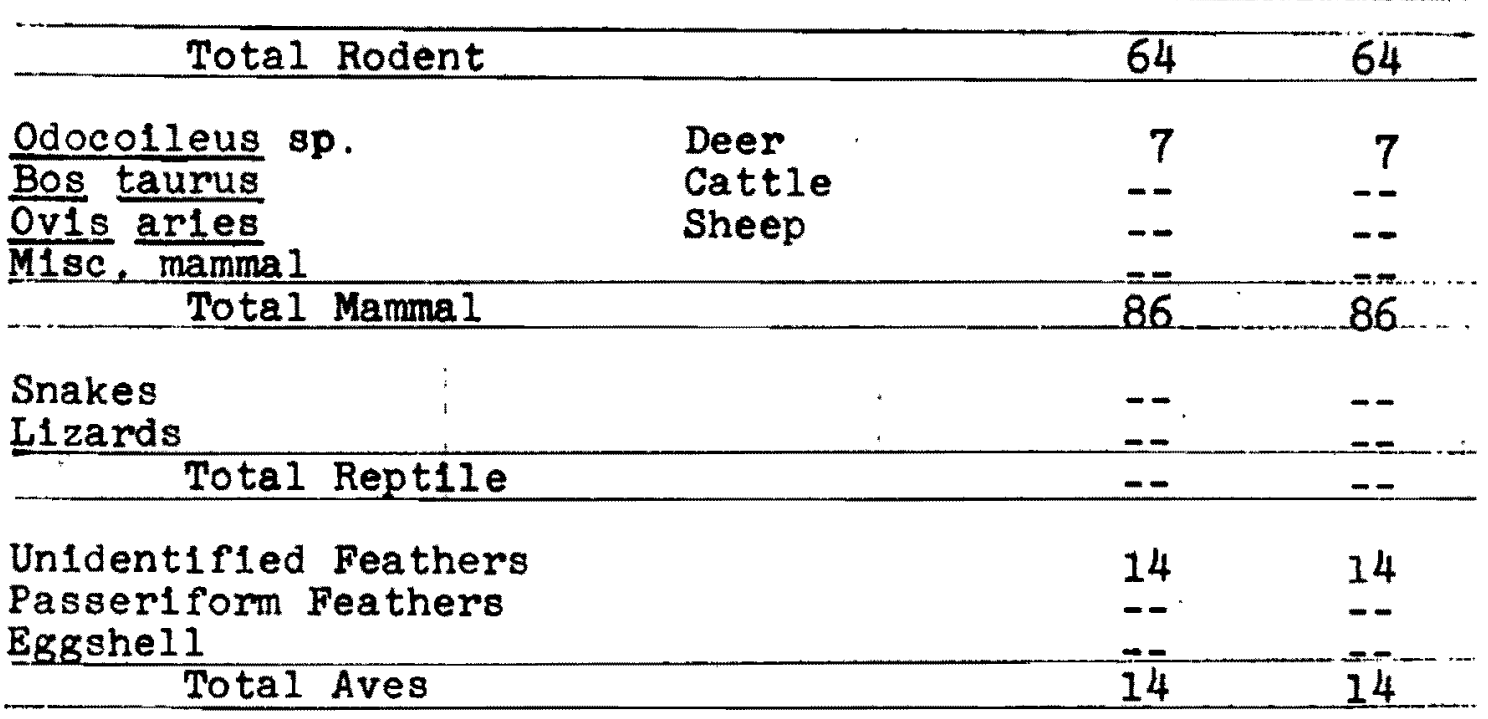

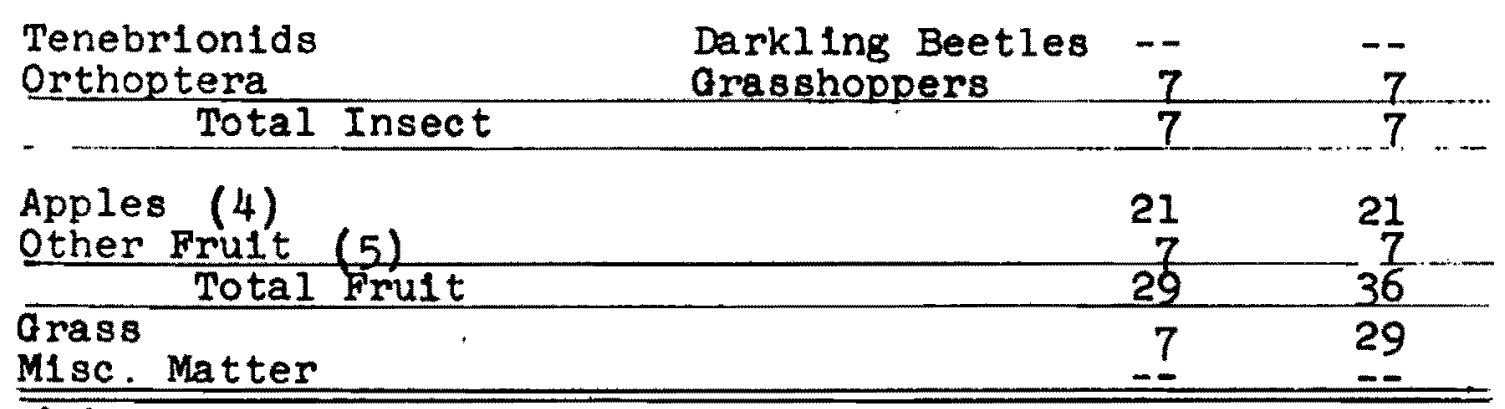

\footnotetext{
(1) Includes scats collected on Feb, 1, 3, and 7, 1975 ( 6 scats); Apr. 5, 1975 (4 scats); Jul. 23, 1975 (4)

(2) All in April and July

(3) All in Pebruary

4) All in February

(5) Cherrles, one occurrence July 23, 1975.
} 
COYOTE SCAT ANALYSIS--USERDA HANPORD RESERVATION

Place 1200 Foot Road Collection Date 16 Sep 75 Analyzed Occurrences Expressed as Percentages Item Major Total

Total Lepor1d $8-8$

Spermoph1lus townsend11 Thomomys telpoldes Perognathus parvus Re1throdontomys megalotis Peromyscus maniculatus Un1dentifled cricetine Microtus montanus Lagurus curtatus Total Microtine

Ground Squirrel Pocket Gopher Pocket Mouse Harvest Mouse Deer Mouse Montane Vole Sagebrush Vole

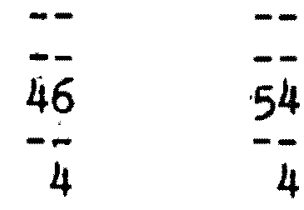

$--$

8
15

Total Rodent

62 65

Odocolleus sp.

Bos taurus

Ov1s aries

M1sc. mammal Total Mammal

Deer

Cattle

Sheep

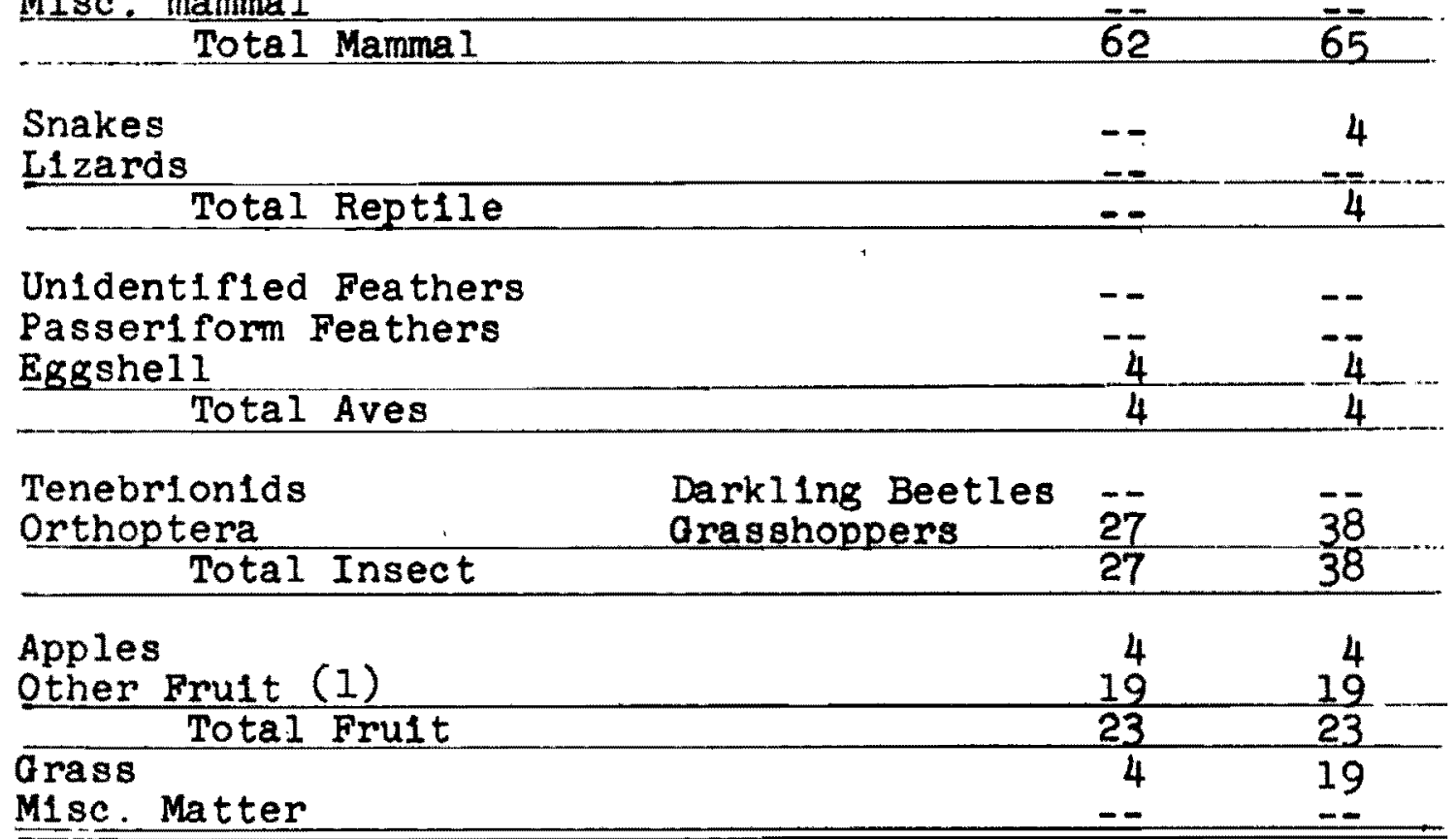

(1) Cherries 
COYOTE SCAT ANALYSIS--USERDA HANPORD RESERVATION

Place 1200 poot Road No. Analyzed Occurrences Expressed as Percentages Item Total Lepor1d Major Total

Total Lepor1d
Spermoph1lus townsend11
$\frac{\text { Thomomys talpoldes }}{\text { Perognathus parvus }}$
$\frac{\text { Reithrodontomys megalot1s }}{\text { Peromysus man1culatus }}$
$\frac{\text { Un1dent1fied cricetine }}{\text { Total cricetine }}$
Microtus montanus Lagurus curtatus Total Microtine 20 20

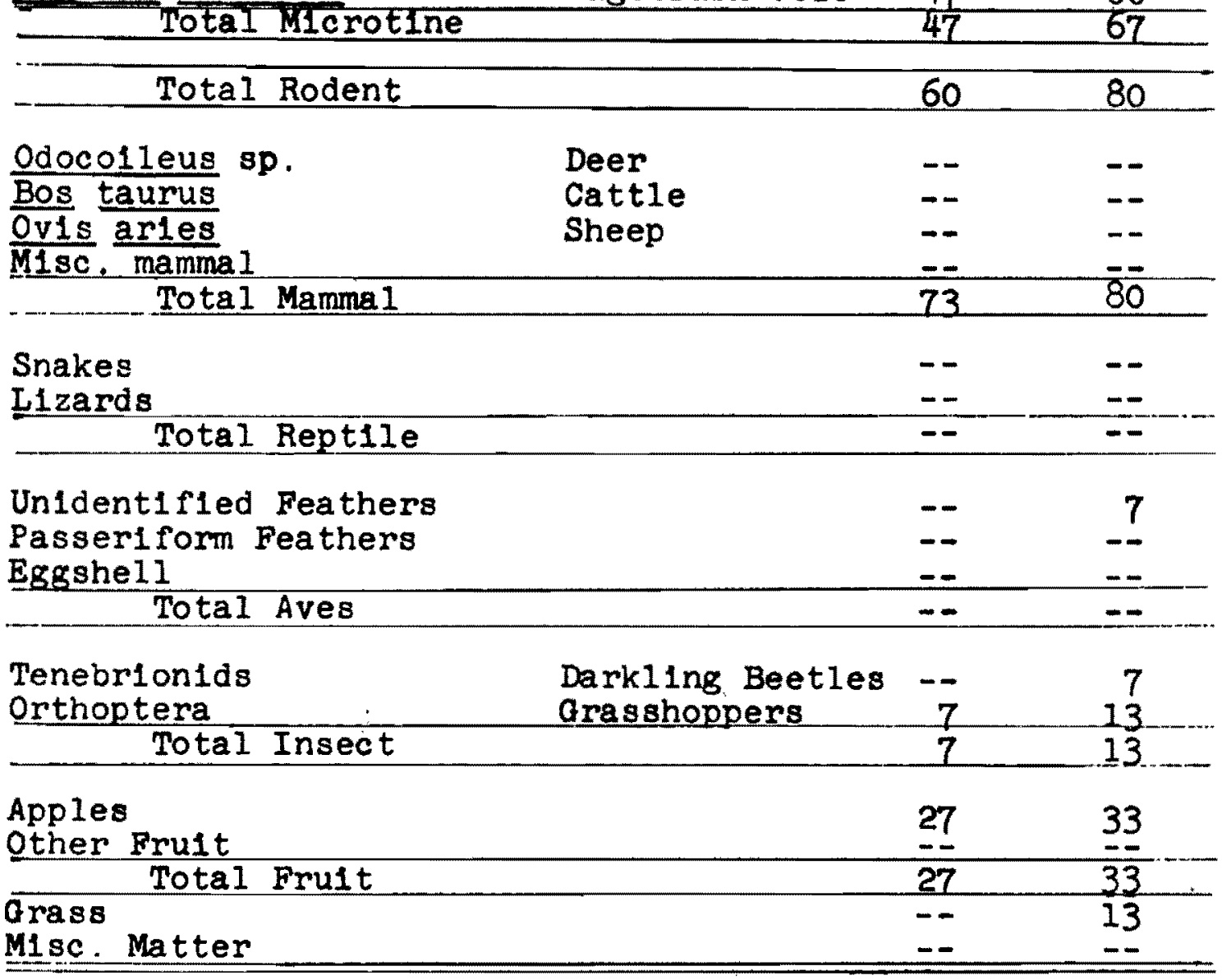


APPENDIX E

COYOTE SCAT ANALYSIS

DRY CREEK ROAD 
COYOTE SCAT ANALYSIS--USERDA HANPORD RESERVATION

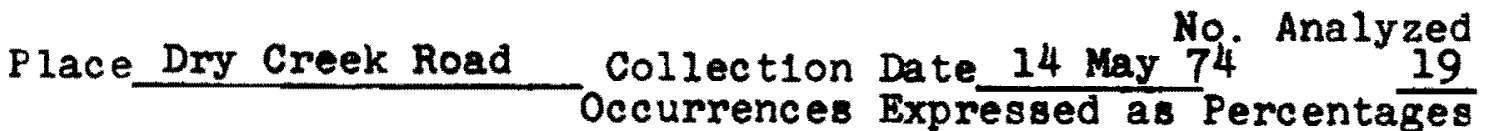
Item Total Leporid Major

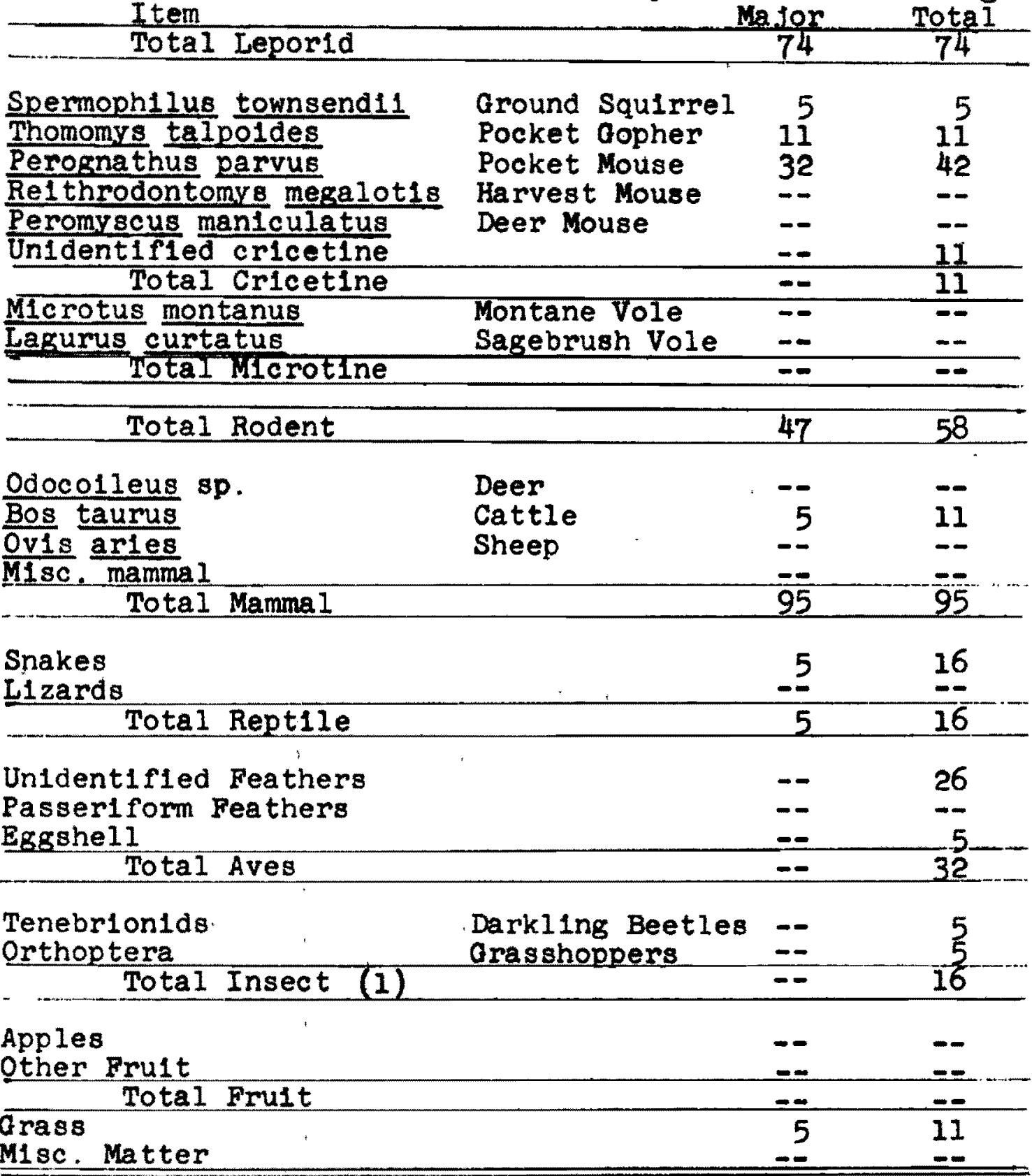

(1) Includes one clcada occurrence 
COYOTE SCAT ANALYSIS--USERDA HANPORD RESERVATION

Place_Dry Creek Road Collection Date_2 Aug 74 . Analyzed Item Occurrences Expressed as Percentages Total Lepor1d Major 36 Total

\begin{tabular}{ccc} 
Item & Major & Total \\
\hline$-\ldots$ Total Lepor1d & 36 & 36
\end{tabular}

Spermoph11us townsend11 Thomomys talpoldes Perognathus parvus Re1throdontomys megalotis Peromyscus maniculatus Unidentifled cricetine Microtus montanus Lagurus curtatus Total Microtine Total Rodent

Ground Squirrel Pocket Gopher Pocket Mouse Harvest Mouse Deer Mouse

\begin{tabular}{cc}
5 & 5 \\
-- & -- \\
32 & 32 \\
-- & -- \\
-- & 5 \\
\hline-- & -- \\
\hline-- & -- \\
-- & $=-$ \\
\hline 36 & 41 \\
\hline
\end{tabular}

Odocolleus sp.

Bos taurus Ovis aries M1sc. mamma 1

Total Mammal

Montane Vole Sagebrush Vole

$$
\text { ne }
$$

(ne

Deer
Cattle
Sheep

Snakes

L1zards Total ReptIle

Unidentifled Feathers Passeriform Fea thers Eggshell

\begin{tabular}{|c|c|}
\hline $\begin{array}{l}\text { Tenebrionids } \\
\text { Orthoptera }\end{array}$ & $\begin{array}{l}\text { Darkling Be } \\
\text { Qrasshopper: }\end{array}$ \\
\hline Total Insect (1) & \\
\hline \multicolumn{2}{|l|}{$\begin{array}{l}\text { Apples } \\
\text { Other Frult (2) }\end{array}$} \\
\hline $\begin{array}{l}\text { Total Fruit } \\
\text { Grass } \\
\text { Misc. Matter }\end{array}$ & \\
\hline$\left(\begin{array}{l}1 \\
2\end{array}\right)$ Includes three clcade & occurre \\
\hline
\end{tabular}


APPENDIX F

COYOTE SCAT ANALYSIS

COLD CREEK ROAD 
COYOTE SCAT ANALYSIS--USERDA HANFORD RESERVATION Place Cold Creek Valley Collection Datespring 74 (1) Analyzed $^{\text {No. }}$ Occurrences Expressed as Percentages Item Total Lepor1d Major 94 Total

\begin{tabular}{|c|c|c|c|}
\hline Total Lepor1d & & 94 & $\frac{10481}{94}$ \\
\hline 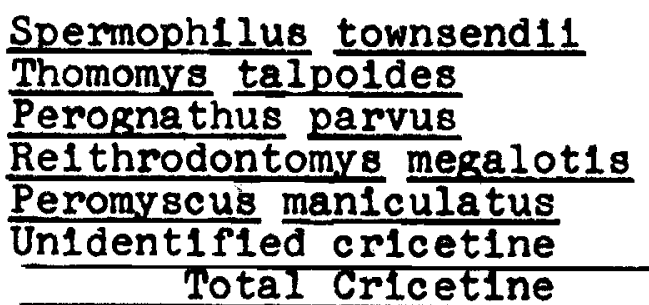 & $\begin{array}{l}\text { Ground Squirrel } \\
\text { Pocket Gopher } \\
\text { Pocket Mouse } \\
\text { Harvest Mouse } \\
\text { Deer House }\end{array}$ & $\begin{array}{r}18 \\
6 \\
12 \\
-- \\
-\frac{6}{6}\end{array}$ & $\begin{array}{r}18 \\
6 \\
24 \\
-9 \\
6 \\
6 \\
12\end{array}$ \\
\hline$\frac{\text { Microtus montanus }}{\text { Lagurus curtatus }}$ & $\begin{array}{l}\text { Montane Vole } \\
\text { Sagebrush Vole }\end{array}$ & $-\infty$ & -- \\
\hline Total Microtine & & $-\infty$ & $=-$ \\
\hline Total Rodent (2) & & 24 & 24 \\
\hline $\begin{array}{l}\text { Odocolleus } \\
\frac{\text { Bos }}{\text { Ovis }} \frac{\text { taurus }}{\text { M1sc. }} \\
\frac{\text { mammal }}{\text { mamma }}\end{array}$ & $\begin{array}{l}\text { Deer } \\
\text { Cattle } \\
\text { Sheep }\end{array}$ & $\begin{array}{l}-- \\
-- \\
--\end{array}$ & $\begin{array}{l}-- \\
-- \\
--\end{array}$ \\
\hline Total Mammal & & 100 & 100 \\
\hline $\begin{array}{l}\text { Snakes } \\
\text { Lizards }\end{array}$ & & - & -- \\
\hline Total Rept1le & & -- & $-=$ \\
\hline $\begin{array}{l}\text { Unidentifled Feathers } \\
\text { Passeriform Feathers (3) } \\
\text { Eggshell }\end{array}$ & & $-\infty$ & $\frac{-}{6}$ \\
\hline Total Aves & & -- & 12 \\
\hline
\end{tabular}

Tenebrionids

Orthoptera Darkling Beetles Grasshoppers Total Insect

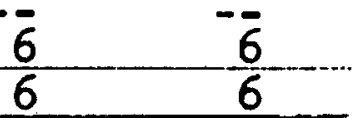

Apples

Other Fruit Grass Total Fruit

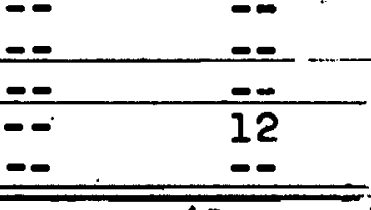

Misc. Matter

(1) Collection dates--Mar. 25 (2 scats), Apr. 1-10 (8 scats) May 16,21 (7 scats)

(2) Includes one porcupine (Erethizon dorsatum) occurrence (3) Horned lark 


\section{APPENDIX G}

\section{COYOTE SCAT ANALYSIS}

N.E. AREA 
COYOTE SCAT ANALYSIS--USERDA HANPORD RESERVATION

Place N. E. Area Collection Date Sumer 74 (1) 28 Occurrences Expressed as Percentages Item Total Leporid Major Total

Apples

Other Fruit (3)

Grass Total Fruit

Misc. Matter

(1) Collection dates-May 15 (1 scat), Jun 24, 29 (2 scats), Jul 4 ( 3 scats), Jul 30,31 (22 scats)

(2) Includes three unidentifled-rodent occurrences

(3) Unidentifled berries 
COYOTE SCAT ANALYSIS--USERDA HANPORD RESERVATION

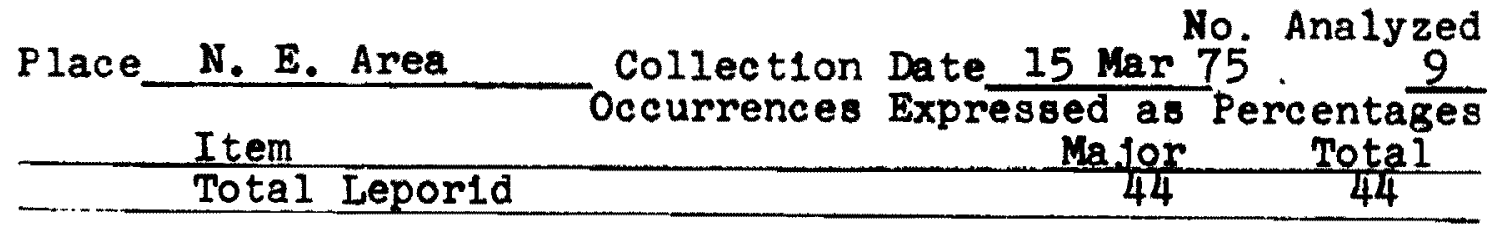

Spermoph1lus townsend11 Ground Squ1rre1

Thomomys talpotdes

Perognathus parvus

Pocket Gopher

Pocket Mouse

Re1throdontomys megalotis

Peromyscus maniculatus

Harvest Mouse

Unidentified cricetine

Deer Mouse

Total Cricetine

Microtus montanus

Lagurus curtatus

rotal Microtine

e

Total Rodent (I)

Montane Vole

Sagebrush Vole

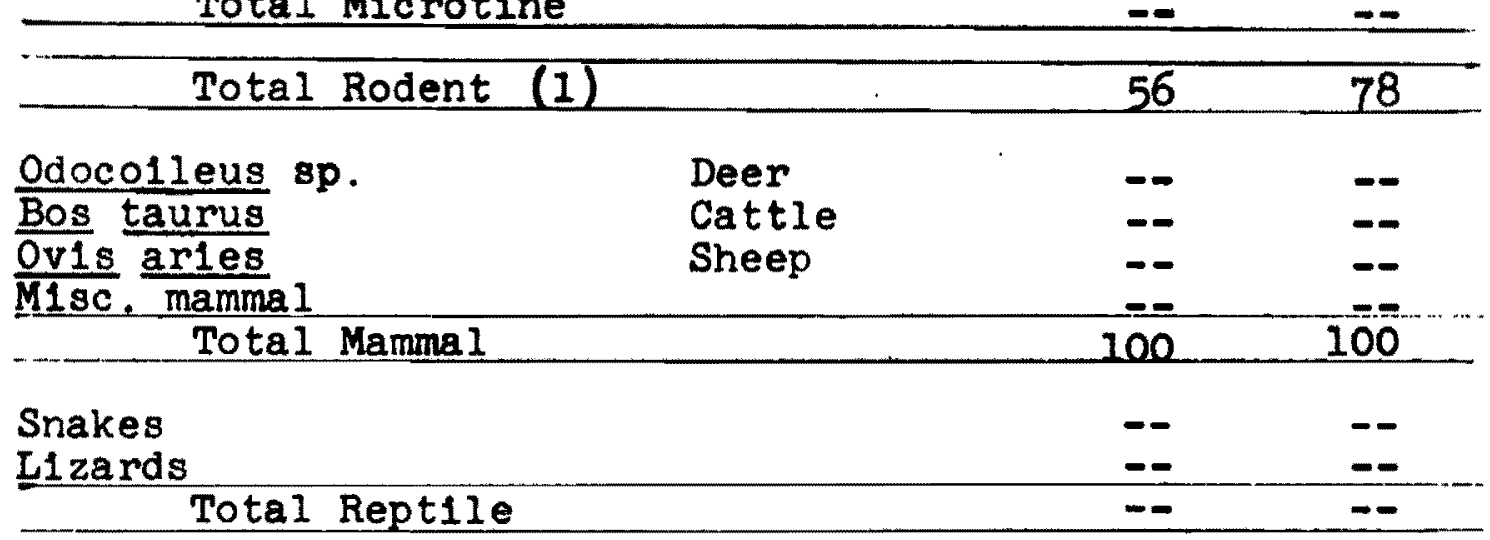

Unidentified Feathers

Passeriform Fea thers

Eggshell

Total Aves

$33 \quad 33$

--

\begin{tabular}{|c|c|c|c|}
\hline Total Aves & & 33 & 33 \\
\hline $\begin{array}{l}\text { Tenebrionids } \\
\text { Orthoptera }\end{array}$ & $\begin{array}{l}\text { Darkling Beetles } \\
\text { arasshoppers }\end{array}$ & $=$ & 11 \\
\hline Total Insect & & -- & 22 \\
\hline Apples & & -- & -- \\
\hline other Frust & & $-\infty$ & $=$ \\
\hline $\begin{array}{l}\text { Total Fruit } \\
\text { Grass } \\
\text { Misc. Matter }\end{array}$ & & -- & $-\infty$ \\
\hline
\end{tabular}

(1) Includes one unidentified-mouse occurrence 
APPENDIX H

NUMBER OF POCKET MICE (Perognathus parvus)

LIVE-TRAPPED ON A ONE HA SQUARE GRID OF

100 TRAPS NEAR RATTLESNAKE SPRINGS, 1971-1976 (P1ot \#24) 


\begin{tabular}{|c|c|c|c|c|c|c|}
\hline & $1971^{1}$ & $1972^{1}$ & $1973^{1}$ & $1974^{2}$ & $1975^{2}$ & $1976^{1}$ \\
\hline Jan & -- & 0 & -- & -- & 5 & -- \\
\hline $\mathrm{Feb}$ & -- & 0 & 1 & 3 & 9 & 0 \\
\hline Mar & 24 & 18,37 & 25 & 22 & 50 & - \\
\hline Apr & 68 & 57 & 38,36 & 52 & 79 & 68 \\
\hline May & 82,71 & 65,49 & 28,40 & 37,35 & 52 & 52 \\
\hline Jun & 73,75 & 37 & 34,29 & 26 & 50 & -- \\
\hline JuI & 73 & 39 & 42 & 35 & 62 & -- \\
\hline Aug & 58,65 & 31,37 & - & 49 & 69 & 41 \\
\hline Sep & 38 & 50 & 31 & 60 & 72 & -- \\
\hline Oct & 38 & 46,37 & 20 & 72 & -- & -- \\
\hline Nov & 32 & 33,11 & 4 & 69 & 33 & 9 \\
\hline $\mathrm{Dec}$ & 0 & 0 & 0 & 16 & - - & -- \\
\hline
\end{tabular}

1 L. E. Rodgers, J. D. Hedlund, K. A. Gano, and T. P. O'Farre11, unpublished data.

2 Rodgers and Hedlund 1976. 